QUALITY OF SURFACE WATERS IN

WILTON, CONNECTICUT

By Kenneth P. Kulp

U.S. GEOLOGICAL SURVEY

OPEN-FILE REPORT 82-260

Prepared in cooperation with the TOWN OF WILTON, CONNECTICUT

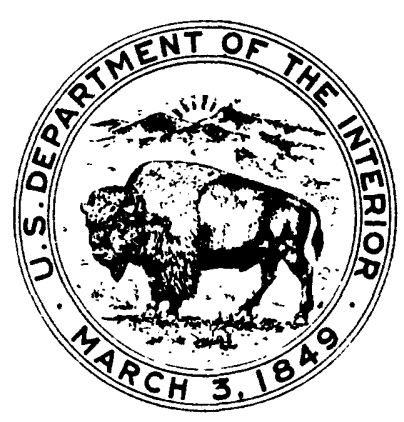

Apri1 1982 
UNITED STATES DEPARTMENT OF THE INTERIOR

JAMES G. WATT, Secretary

GEOLOGICAL SURVEY

Dallas L. Peck, Director

For additional information write to:

U.S. Geological Survey

Room 525, 450 Ma in Street

Hartford, Connecticut 06103 
TABLE OF CONTENTS

Page

Abstract................................................. 1

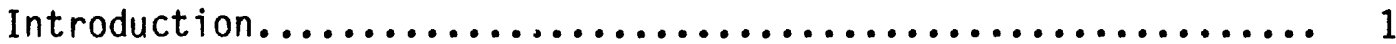

Description of the study area......................... 1

Stream systems...................................... 3

Geology.......................................... 3

Methods and techniques................................ 4

Water quality..................................... 5

West Branch Saugatuck River near Weston.................. 12

Norwalk River at Georgetown.............................. 12

Norwalk River at Cannondale............................ 14

Comstock Brook at North Wilton........................... 14

Bryant Brook at Wilton................................ 16

Norwalk River at South Wilton........................... 16

East Branch Silvermine River near Ridgefield............... 18

East Branch Silvermine River near North Wilton............... 18

Thayers Brook near Silvermine........................... 19

Silvermine River near Silvermine....................... 19

Bottom materials................................. 20

Biological.......................................... 20

Summary............................................ 21

Selected references.................................... 51 


\section{ILLUSTRATIONS}

Figure

Page

1. Map showing study area and sampling site locations...... 2

2. Map showing State of Connecticut classifications for streams in study area......................... 10

\section{TARLES}

Table

1. Sampling site identification, location, and drainage areas, 3

2. Sampling frequency at sites..................... 4

3. Water-quality criteria.......................... 6

4. Source and significance of chemical constituents and physical properties of water.................... 7

5. Classification standards for Connecticut inland waters..... 11

6. Summary of data from Norwalk River at Genrgetown.......... 13

7. Summary of data from Norwalk River at Cannondale.......... 15

8. Summary of data from Norwalk River at South Wilton......... 17

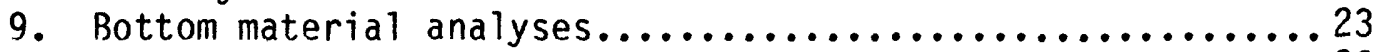

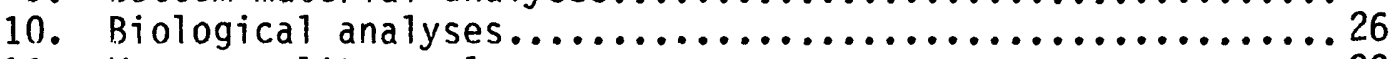

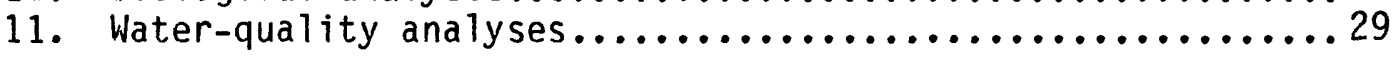

FACTORS FOR CONVERTING INCH-POUND UNITS TO INTERNATIONAL SYSTEM UNITS (SI)

Multiply inch-pound unit

\section{foot (ft)}

mile (mi)

square mile $\left(m i^{2}\right)$

acre-foot (acre-ft)

ton (short)

cubic foot per

second $\left(\mathrm{ft}^{3 / \mathrm{s}}\right)$

micromho per

centimeter (umho/cm)

degree Fahrenheit ( ${ }^{\circ} \mathrm{F}$ )
By

0.3048

1.609

2.590

1,233

0.9072

0.02832

1.000

${ }^{\circ} \mathrm{C}=\left({ }^{\circ} \mathrm{F}-32\right) / 1.8$
To obtain SI units

meter (m)

kilometer $(\mathrm{km})$

square $\mathrm{kil}$ ometers $\left(\mathrm{km}^{2}\right)$

cubic meter $\left(\mathrm{m}^{3}\right)$

megagram (Mg)

cubic meter per second $\left(\mathrm{m}^{3} / \mathrm{s}\right)$

microsiemen per

centimeter (uS/cm)

degree Celcius $\left({ }^{\circ} \mathrm{C}\right)$ 


\title{
QUALITY OF SURFACE WATERS IN WILTON, CONNECTICUT
}

\author{
By
}

Kenneth P. Kulp

\section{ABSTRACT}

Water, bed material, and biological samples were collected and analyzed at 10 surface-water gaging sites on six streams in the Town of Wilton, Connecticut over a 2-year period. The data indicate fair to excellent water quality. Fecal coliform bacteria, $\mathrm{pH}$, alkalinity, iron, and manganese are the parameters that most often exceed recommended limits established by either the U.S. F.nvironmental Protection Agency or the Connecticut Department of Environmental Protection.

Data from sites on the Norwalk and East Branch Silvermine Rivers indicate little if any undesirable changes in water quality take place as they flow through the study area.

\section{INTRODUCTION}

In April 1976, the U.S. Geological Survey, in cooperation with the Town of Wilton, Conn., began a program of collecting water-quality data. The objectives of the program were to determine haseline water-quality data of the major rivers and streams, and to evaluate downstream changes in the quality of the Norwalk and Silvermine Rivers.

Data collection ended in April 1978. This report summarizes the program and presents all the data collected.

\section{DESCRIPTION OF THE STUDY AREA}

The Town of Wilton is in the southwest corner of Connecticut, north of the city of Norwalk, in Fairfield County (fig. 1). The town is predominantly suburban, with some light industry. In recent years, the area has undergone rapid development, which will probably continue.

Based on records of the Norwalk River at South Wilton, streamflows for the 1976 water year (0ct. 1, 1975 - Sept. 30, 1976) were approximately 70 percent above average. Streamflows in the 1977 water year were 93 percent of average and in the 1978 water year were 55 percent of average.

Ten sites were sampled. Their locations are shown on figure 1, and other information is given in table 1 . 


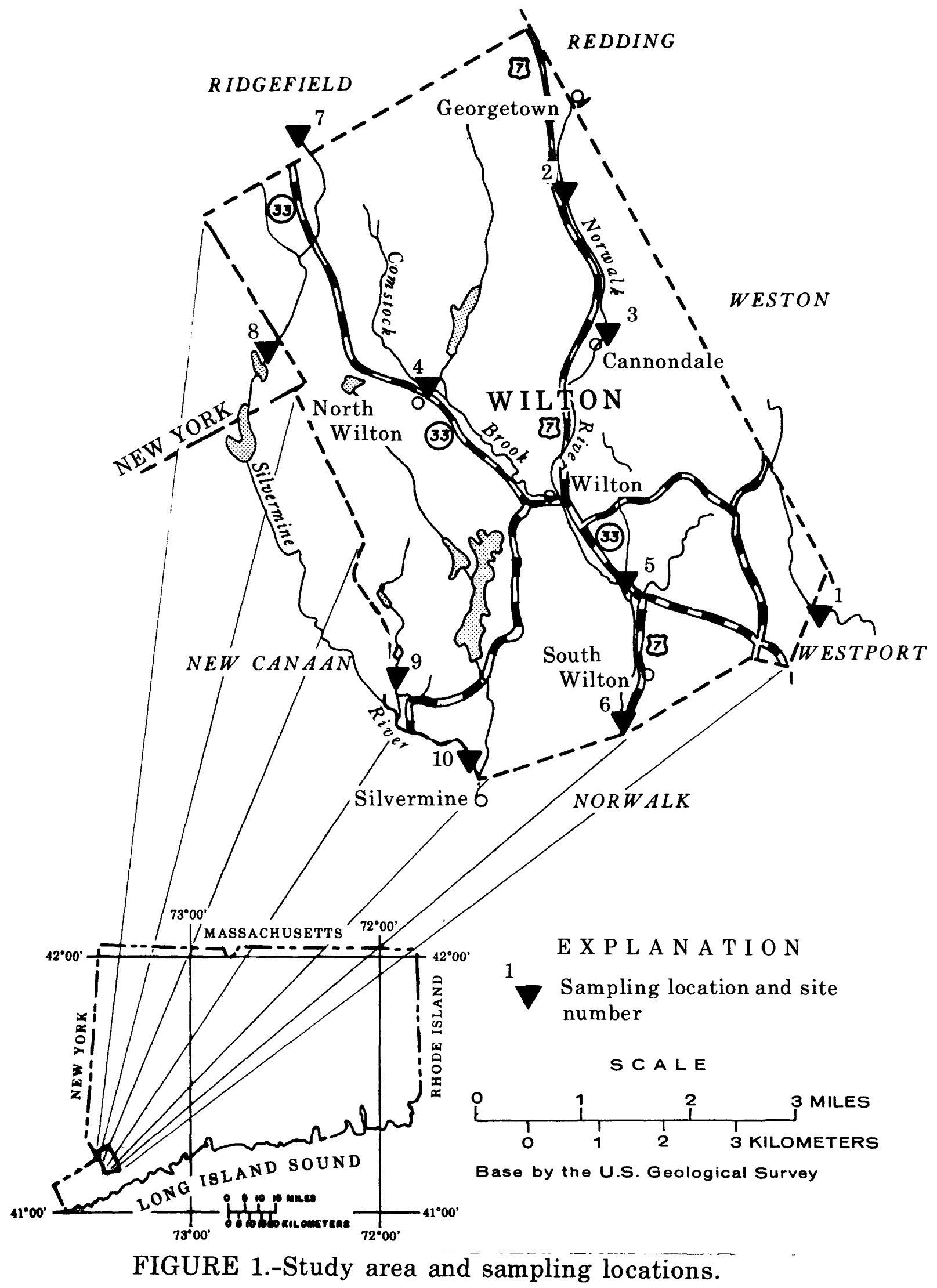


Table 1.--Sampling site identification, location, and drainage area

\begin{tabular}{|c|c|c|c|c|c|c|}
\hline \multirow{2}{*}{$\begin{array}{l}\text { Pro- } \\
\text { ject } \\
\text { site } \\
\text { no. }\end{array}$} & \multirow{2}{*}{$\begin{array}{l}\text { USCS } \\
\text { station } \\
\text { No. }\end{array}$} & \multirow{2}{*}{ Name } & \multicolumn{2}{|c|}{ Coordinate } & \multirow{2}{*}{$\begin{array}{l}\text { Drainage } \\
\text { areag } \\
\left(m i \frac{2}{-}\right)\end{array}$} & \multirow{2}{*}{ Location } \\
\hline & & & Latitude & Longitude & & \\
\hline 1 & 01209400 & $\begin{array}{l}\text { West Branch Saugatuck } \\
\text { River near Weston, Conn. }\end{array}$ & $41^{\circ} 10^{\prime} 41^{\prime \prime}$ & $73^{\circ} 22^{\prime} 50^{\prime \prime}$ & 10.8 & $\begin{array}{l}\text { At Newt on Turnpike bridge, } \\
1.5 \text { miles south of Weston, Conn. }\end{array}$ \\
\hline 2 & 01209570 & $\begin{array}{l}\text { Norwalk River at } \\
\text { Georgetown, Conn. }\end{array}$ & $41^{\circ} 14^{\prime} 45^{\prime \prime}$ & $73^{\circ} 26^{\prime} 05^{\prime \prime}$ & 14.5 & $\begin{array}{l}\text { At bridge on 0ld Mill Road, } \\
0.8 \text { mile south of Georget own, Conn. }\end{array}$ \\
\hline 3 & 01209572 & $\begin{array}{l}\text { Norwalk River at } \\
\text { Cannondale, Conn. }\end{array}$ & $41^{\circ} 13^{\prime} 52^{\prime \prime}$ & $73^{\circ} 25^{\prime} 35^{\prime \prime}$ & 15.2 & $\begin{array}{l}\text { At bridge on Honey Hill Road, } \\
1 \text { mile north of Cannondale, Conn. }\end{array}$ \\
\hline 4 & 01209600 & $\begin{array}{l}\text { Coinstock Brook at } \\
\text { North Wilton, Conn. }\end{array}$ & $41^{\circ} 12^{\prime} 45^{\prime \prime}$ & $73^{\circ} 27^{\prime} 31^{\prime \prime}$ & 3.53 & $\begin{array}{l}\text { At bridge on Nod Hill Road, } \\
\text { at North Wilton, Conn. }\end{array}$ \\
\hline 5 & 01209680 & $\begin{array}{l}\text { Bryant Brook at } \\
\text { Wilton, Conn. }\end{array}$ & $41^{\circ} 11^{\prime} 01^{\prime \prime}$ & $73^{\circ} 25^{\prime} 09^{\prime \prime}$ & 0.99 & $\begin{array}{l}\text { At U.S. Route } 7 \text { bridge, } \\
\text { I mile southeast of Wilton, Conn. }\end{array}$ \\
\hline$\dot{5}$ & 01209700 & $\begin{array}{l}\text { Norwalk River at } \\
\text { South Wilton, Conn. }\end{array}$ & $41^{\circ} 09^{\prime} 49^{\prime \prime}$ & $73^{\circ} 25^{\prime} 11^{\prime \prime}$ & 30.0 & $\begin{array}{l}\text { At bridge on Kent Road, } \\
\text { at South Wilton, Conn. }\end{array}$ \\
\hline 7 & 0.1209715 & $\begin{array}{l}\text { East Branch Silvermine } \\
\text { River near Ridgefield, Conn. }\end{array}$ & $41^{\circ} 14^{\prime} 59^{\prime \prime}$ & $73^{\circ} 29^{\prime} 03^{\prime \prime}$ & 1.36 & $\begin{array}{l}\text { At Gay Road bridge, } 2.5 \text { miles } \\
\text { southeast of Ridgefield, Conn. }\end{array}$ \\
\hline 8 & 01209716 & $\begin{array}{l}\text { East Branch Silvermine } \\
\text { River near North Wilton, Conn. }\end{array}$ & $41^{\circ} 13^{\prime} 08^{\prime \prime}$ & $73^{\circ} 29^{\prime} 28^{\prime \prime}$ & 2.64 & $\begin{array}{l}\text { At Silver Spring Road bridge by } \\
\text { Browns Reservoir, N.Y. } 1.5 \text { miles } \\
\text { northwest of North Wilton, Conn. }\end{array}$ \\
\hline 9 & 01209730 & $\begin{array}{l}\text { Thayers Brook near } \\
\text { Silvermine, Conn. }\end{array}$ & $41^{\circ} 10^{\prime} 10^{\prime \prime}$ & $73^{\circ} 27^{\prime} 51^{\prime \prime}$ & 1.59 & $\begin{array}{l}\text { At Huckleberry Hill Road bridge, } \\
\text { below Domenicks Pond, } 1.5 \text { miles } \\
\text { northwest of Silvermine, Conn. }\end{array}$ \\
\hline 10 & 01209734 & $\begin{array}{l}\text { Silvermine River } \\
\text { near Silvermine, Conn. }\end{array}$ & $41^{\circ} 09^{\prime} 25^{\prime \prime}$ & $73^{\circ} 27^{\prime} 01^{\prime \prime}$ & 16.0 & $\begin{array}{l}\text { At bridge on private road, } \\
0.5 \mathrm{mile} \text { north of Silvermine, Conn. }\end{array}$ \\
\hline
\end{tabular}

\section{Stream Systems}

Three rivers flow through Wilton. The principal river is the Norwalk, with a drainage area of $30.0 \mathrm{mi}^{2}\left(77.7 \mathrm{~km}^{2}\right)$ at South Wilton: other rivers are the Silvermine, drainage area of $16.0 \mathrm{mi}^{2}\left(41.4 \mathrm{~km}^{2}\right)$ near Silvermine, and the West Branch Saugatuck, drainage area of $10.8 \mathrm{mi}^{2}\left(28 \mathrm{~km}^{2}\right)$ at Weston. The Silvermine River flows into the Norwalk River at Norwalk, just before it enters Long Island Sound. The West Branch Saugatuck River joins the Saugatuck River north of Weston, and flows into Long Island Sound at Saugatuck. Significant small streams are Comstock Brook and Bryant Brook, tributaries to the Norwalk River, and Thayers Brook, a tributary to the Silvermine River.

\section{Geology}

The study area is underlain by gneiss and other metamorphic and igneous rocks (Kroll, 1977). The bedrock is discontinuously mantled by unconsolidated deposits, primarily of glacial origin. The most widespread unconsolidated deposits are till, that occurs in upland areas and stratified drift, that is generally confined to major valleys (Ryder and others, 1970). 


\section{METHODS AND TECHNIQUES}

During the initial phase of the program, April to June 1976, each of the 10 sites was sampled monthly. Subsequent sampling was restricted to the three Norwalk River sites. These sites were sampled approximately every month through November 1977 and in March and April 1978.

The water at each site was analyzed in the field for temperature, specific conductance, $\mathrm{pH}$, dissolved oxygen, total and fecal coliform, and fecal streptococci bacteria. Samples were also collected and analyzed for selected chemical constituents. Streamflow was measured at each site when samples were collected. The methods and techniques used to collect and analyze the samples are described by Brown and others (1970), Greeson and others (1977), and Buchanan and Somers (1969).

In addition, bed material and biological studies were carried out at sites 2, 3, and 4 in June 1976. Bed material samples were analyzed for metals and pesticides. Samples of suspended or floating plant life (phytoplankton), algae attached to submerged substrates (periphyton), and bottom dwelling animals (benthic invertebrates) were collected and analyzed for numbers, types, and community structure. The water was also analyzed for algal growth potential (AGP), a measure of its ability to support plant life.

A summary of the sampling frequency at each site is given in table 2 .

Table 2.--Sampling frequency at sites

\begin{tabular}{cccc}
$\begin{array}{c}\text { Site } \\
\text { No. }\end{array}$ & $\begin{array}{c}\text { Time } \\
\text { period }\end{array}$ & $\begin{array}{c}\text { Number of } \\
\text { water samples }\end{array}$ & $\begin{array}{c}\text { Number of bed } \\
\text { material and } \\
\text { biological samples }\end{array}$ \\
\hline 1 & Apr. 1976-June 1976 & 3 & -- \\
2 & Apr. 1976-Apr. 1978 & 22 & 1 \\
3 & Apr. 1976-Apr. 1978 & 22 & 1 \\
4 & Apr. 1976-June 1976 & 3 & - \\
5 & Apr. 1976-June 1976 & 3 & -- \\
6 & Apr. 1976-Apr. 1978 & 22 & - \\
7 & Apr. 1976-June 1976 & 3 & - \\
8 & Apr. 1976-June 1976 & 3 & - \\
9 & Apr. 1976-June 1976 & 3 & - \\
10 & Apr. 1976-June 1976 & 3 & \\
& & & \\
\hline
\end{tabular}




\section{WATER QUALITY}

Results of the water sampling program have been evaluated on a site-by-site basis, using the criteria in table 3 , which indicate limiting values of various chemical constituents and physical properties of water based on the protection of water users, aquatic organisms, and aesthetic value.

Additional information concerning the sources and significance of selected chemical, physical, and biological properties of water determined in this study are contained in table 4 . The results of the bed material and biological studies are discussed separately, as they were not performed at all sites.

A1l of the water-quality data collected are given in table 11. For most sites, data collected have been compared with Connecticut Water Quality Standards and Classifications (Connecticut Department of Environmental Protection, 1977).

The official State classification of the waters investigated in this study are shown in figure 2, and a condensed 1 ist of the classification standards is shown in table 5. (For more detailed information on the classification of various reaches of streams and the State classification standards, refer to the cited publication.) Because all parameters contained in the State's quality standards were not determined in this study and the number of analyses for any site is limited, it is not possible to assess how the water should be classified according to the state standards. 


\begin{tabular}{|c|c|c|c|}
\hline $\begin{array}{l}\text { Chemical constituent } \\
\text { or physical property }\end{array}$ & $\begin{array}{l}\text { Limiting } \\
\text { value }\end{array}$ & Use & $\begin{array}{l}\text { Basis for } \\
\text { selection }\end{array}$ \\
\hline $\begin{array}{l}\text { Alkalinity, total } \\
\left.\text { (as } \mathrm{CaCO}_{3}\right)\end{array}$ & $\mathrm{a} 20 \mathrm{mg} / \mathrm{L}$ & 1 & A \\
\hline Cnloride & $250 \mathrm{mg} / \mathrm{L}$ & 4 & $c$ \\
\hline Coliforin Bacteria, Fecal & $\begin{array}{r}\mathrm{b}_{20 \mathrm{col} / 100 \mathrm{~mL}} \\
\mathrm{c}_{200 \mathrm{col} / 100 \mathrm{~mL}} \\
\mathrm{~b}_{1}, 000 \mathrm{col} / 100 \mathrm{~mL}\end{array}$ & $\begin{array}{l}3 \\
6 \\
5\end{array}$ & $\stackrel{D}{A, D}$ \\
\hline Color & $\begin{array}{l}d_{15} \text { color units } \\
\text { d75 color units }\end{array}$ & $\begin{array}{l}4 \\
2\end{array}$ & $\begin{array}{l}C \\
\AA\end{array}$ \\
\hline Copper & $1,000 \mathrm{ug} / \mathrm{L}$ & 2,4 & $A, C$ \\
\hline Iron & $\begin{array}{r}300 \mathrm{ug} / \mathrm{L} \\
1,000 \mathrm{ug} / \mathrm{L}\end{array}$ & 2,4 & $\stackrel{A, C}{A}$ \\
\hline Lead, dissolved & $50 \mathrm{ug} / \mathrm{L}$ & 2,3 & $A, B$ \\
\hline Manganese & $50 \mathrm{ug} / \mathrm{L}$ & 2,4 & $A, C$ \\
\hline $\begin{array}{l}\text { Methylene Blue } \\
\text { Active Substance }\end{array}$ & $0.5 \mathrm{mg} / \mathrm{L}$ & 4 & c \\
\hline Nitrate (as N) & $10 \mathrm{mg} / \mathrm{L}$ & 2,3 & $A, B$ \\
\hline Nitrite (as N) & $1 \mathrm{mg} / \mathrm{L}$ & 2 & A \\
\hline Oxygen, dissolved & $\begin{array}{l}\text { a5 } \mathrm{mg} / \mathrm{L} \\
\text { a } 4 \mathrm{mg} / \mathrm{L}\end{array}$ & $\begin{array}{l}1 \\
6\end{array}$ & $\begin{array}{c}A, D \\
D\end{array}$ \\
\hline $\mathrm{pH}$ & $\begin{array}{l}5.0-9.0 \\
6.0-8.5 \\
6.5-8.0 \\
6.5-8.5 \\
6.5-9.0\end{array}$ & $\begin{array}{c}2 \\
1,6 \\
5 \\
4 \\
1\end{array}$ & $\begin{array}{c}A \\
D \\
D \\
A, C \\
A\end{array}$ \\
\hline Sodium & $20 \mathrm{mg} / \mathrm{L}$ & 3 & D \\
\hline Solids, dissolved & $500 \mathrm{mg} / \mathrm{L}$ & 4 & c \\
\hline Sulfate & $250 \mathrm{mg} / \mathrm{L}$ & 4 & C \\
\hline Turbidity & $\begin{array}{c}\mathrm{e}_{25} \text { Jackson turbidity } \\
\text { units (JTU) }\end{array}$ & 1 & D \\
\hline Zinc & $5,000 \mathrm{ug} / \mathrm{L}$ & 2,4 & $A, C$ \\
\hline
\end{tabular}

Water use and(or) for the Protection of:

1. Freshwater aquatic life

2. Donestic water supply source

3. Potable drinking water, based on hedith effects

4. Potable drinking water, based on aesthetic considerations

5. Prinary cuntact

6. Aesthet ic value

\section{Basis for Selection}

A. Maximum levels recommended by: Quality Criteria for Water, 1977, U.S. Environiental Protection Agency.

B. Maxinum containinant level established by: National Interin Prinary Drinking Water Rejulations 1975, 11.S. Environenental Protection Agency.

C. Maximuri contadiinant level recomnended for the Proposed National Secondary Drinking Hater Regulations, 1977, U.S. Environnental Protection Agency.

D. Maximum levels established by: State of Connecticut Water quality Standards, 1980, Connecticut Department of Environmental Protection (see Table 5).

a/ Minimum recomended value.

b/ Arithinetic mean.

c/ Log mean, based on a minimum of five samples.

$\bar{d} /$ As determined by use of the platinum-cobalt method (Standard Methods, 1971).

e/ Unit of measurement based on the Jackson candle turbidimeter. 
Alkalinity

Calcium (Ca) and magnesium ( $\mathrm{Mg}$ )

Carbon (C) organic

Carbon dioxtde ( $\left.\mathrm{CO}_{2}\right)$

Carbonate $\left.\mathrm{CCO}_{3}\right)$ and bicarbonate $\left.\mathrm{CHCO}_{3}\right)$

Chloride $(\mathrm{Cl})$

Coliform, total

Coliforin, fecdl

Color

Copper (Cu)

Hardness

Iron (Fe)

Lead (PD)

Manganese (Mn)

Yethylene blue active suostance (MBAS)
The capacity to neutralize acid, which is usually produced by dissolved carbonates, bicarbonates, and(or) hydroxides in the water.

Dissolved from rocks and soils, especially those containing calcium stlicates, clay minerals, and carbonate lenses.

Derived from organic material.

Derived fron atmosphere, respiration of aquatic oryanisins, decomposition of organic matter, and breakjown of bicarbonate due to acids.

Dissolved fron carbonate and calcfun sllicate minerals by reaction with carbon dioxide in water. Decaying vegetation, sewage, and industrial wastes are also important sources.

Dissolved from rocks and soils in small amounts. other sources are animal wastes, sewage, road salt, industrial wastes, and seawater.

A group of bacteria widely distributed in the environment, some types live in soll, others live in the intestinal tract of warm blooded antmals.

Type of coliform bacteria which live in the intestinal tract of warm blooded animals, including humans. Enter water by way of fecal wastes of these animals.

May be imparted by iron and manganese compounds, algae, weeds, and humus. May also be caused by inorganic or organic wastes from industry. True color of water is considered to be only that remaining in solution after the suspended material has been removed.

Presence in more than trace concentrations is usually derived from corrosion of copper pipes, industrial wastes, and copper salts used as algacides and herbicides.

Primarily due to calcium and inagnestum, and to a lesser extent to iron, manganese, aluminum, barium, and strontium. There are two classes of hardness: carbonate (temporary) and noncarbonate (perinanent). Carbonate hardness refers to the hardness baianced by equivalents of carbonate and bicarbonate ions; noncarbonate refers to the remainder of the hardness. Most waters in the basin are classified as soft to moderately hard.

Dissolved from minerals that contain oxides, sulfides, and carbonates of iron. Decaying vegetation, iron objects that are in contact with water, sewage, and industrial waste are also major sources.

Atinospheric deposition, erosion, and leaching of soll and rocks, and municipal and industrial waste.

Dissolved from many rocks and soils. Commonly associated with iron in natural waters but less comnon.

A measure of the concentrations of apparent deteryents in water. The most common sources are synthetic household detergent residues in sewage and waste waters.
The buffering capacity of water relates to $\mathrm{pH}$, which has direct and indirect effects on aquatic IIfe, and other uses of water.

Hardness and scale-forming properties of water are caused principally by dissolved bicarbonates and sulfates of calcium and magnesium. (See hardness.) Hard water is objectionable for electroplating, tanning, dyeing and textile processing. It also causes scale formation in steam boflers. water heaters, and pipes.

Indicative of organic pollution loads

Can have detrimental effects on fish, and contributes to the corrosiveness of the water

Carbonates of calctum and magnesfum cause hardness, form scale in botlers and pipes, and release corrosive carbon dioxide gas. (See hardness.) Water of low mineral content and low bicarbonate content in proportion to carbon dioxide is acidic and corrosive.

Large amounts in combination with calcium will result in a corrosive solution and in combination with sodiun will give water a salty taste.

As aroup are generally considered harmless. Coliforms in water are considered indicators of possible warm-blooded animal waste contamination, including that of humans.

Presence in water specifically indicates fecal waste contamination by warm blooded antinals.

Water for donestic and some industrial uses should be free of perceptible color. Color in water is objectionable in food and beverage processing and many manufacturing processes.

Imparts an objectionable taste to water, toxic to some aquatic organisms. Undesirable in water for some industrial uses.

Hard water uses more soap to lather and deposits soap curds on bathtubs. Water having a hardness of more than $120 \mathrm{mg} / \mathrm{L}$ is commonly softened for domestic use. Hardness forins scale in botlers, water heaters, radiators, and pipes, causing a decrease in rate of heat transfer and restricted flow of water. In contrast, water having a very low hardness inay be corrosive.

On exposure to air, iron in ground water oxidizes to a reddish-brown precipitate. More than about $300 \mathrm{ug} / \mathrm{L}$ stains laundry and utensils, causes unpleasant odors, and favors growth of iron bacteria. Iron in water is objectionable for food and textile processing. Most iron-bearing water. when treated by aeration and filtration, are satisfactory for donestic use.

A cumulative poison to antinals, including man.

More than $50 \mathrm{ug} / \mathrm{L}$ oxidizes to a black precipitate. Manganese has the same undesirable characteristics as iron but is more difficult to remove.

High concentration of detergents cause undestrable taste, foaming, and odors. Indicates possible presence of sewage or industrial waste. Low values of MBAS may also be reflective of phenols. proteins, inorganic chlorides, cyanates, nitrates, thiocyanates, and organic compounds having ainine groups, which also give positive results to the MBAS deterinination. Some of these substances inay occur naturally. 
Nitrogen (N)

Anmonia $\left(\mathrm{NH}_{4}\right)$

Nitrate $\left(\mathrm{NO}_{3}\right)$

Nitrite $\left(\mathrm{NO}_{2}\right)$

Oxyyen, dissolved $(0.0$.

$\mathrm{pH}$

Phosphorus (P)

Silica $\left(\mathrm{SiO}_{2}\right)$

Sodium ( $\mathrm{Na}$ )

Solids, dissolved

Specific conductance

Streptococci, fecal

Sulfate $\left(\mathrm{SO}_{4}\right)$
Derived froin the atmosphere, leaching froin rocks, and soils, decomposition of organic materials, and various biological processes. Al so from fertilizers, municipal and industrial wastes and sewage.

A deyradation product of nitrogenous organic inaterial. Also derived from industrial wastes.

Sewaye, industrial wastes, fertilizers, and decaying vegetation are inajor sources. Lesser amounts are derived from precipitation and solution processes.

An intermediate product of the nitrification process. Formed from the nitrate or ammonium ions by micro-organisms found in water, soil, sewage, and aninal digestive tracts.

Derived froin the atmosphere and froin photosynthes is by aquatic vegetation. Amount varies with temperature and pressure and decreases during

breakdown of waste material. Concentration can be expressed in $\mathrm{mg} / \mathrm{L}$ or as a percentage of saturation.

Water having concentrations of acids, acidgenerating salts, and free carbon dioxide has a low pH. Where carbonates, bicarbonates, hydroxides, phosphates and silicates are dominant, the $\mathrm{pH}$ is high. Most natural waters range between 6 and 8 .

Leaching of solls and rocks, fertilizer, decomposition of plants and animals, sewage, and industrial effluents.

Dissolved from practically all rocks and soils.

Dissolved from practically all rocks and solls. Sewage, industrial wastes, road salt, and sea water are also major sources. Most home water softeners increase the amount of sodium in water by exchanging it for calcium and magnesium.

Includes dil dissolved inineral constituents derived froin solution of rocks and soils. Locally auginented by mineral matter in sewaye and industrial wastes. Measured as residue on evaporation at $180^{\circ}$ or calculated as numerical sum of ainounts of individual constituents.

Specific conductance, or the capacity of water to conduct an electric current. Reflects geochenistry of basin, also affected by pollution.

A group of bacteria which live in the intestinal tract of warin blooded animals. Enter water with animal fecal matter.

Dissolved from rocks and solls containing sulfur compounds, especially iron sulfide; also from sulfur compounds dissolved in precipitation and sewage and industrial wastes.
Combines with other elenents and at various oxidation states to forin cheinical species such as annonia, nitrate, and nitrite.

Indicative or organic pollution and toxtc to aquatic organisms.

Small amounts have no affect on usefulness of water. A concentration greater than $10 \mathrm{mg} / \mathrm{L}$ generally indicates pollution. Nitrate encourages growth of algae and other organisms which produce undesirable tastes and odors. Water containing more than $44 \mathrm{mg} / \mathrm{L}$ has reportedly caused methenoglobemia, which is often fatal to infants (Comly, 1945). Recomnended maximum $10 \mathrm{mg} / \mathrm{L}$ of nitrate expressed as $N$, which is equivalent to $44 \mathrm{mg} / \mathrm{L}$ nitrate expressed as $\mathrm{NO}_{3}$

Very unstable in the presence of oxygen, therefore it is found in minute quantities in most natural waters. It is sometimes indicative of organic pollution.

Dissolved oxygen in surface water is necessary for support of fish and other aquatic life. It causes precipitation of iron and manganese in well water and can cause corrosion of metals.

A $\mathrm{pH}$ of 7.0 indicates neutrality of a solution. Values higher than 7.0 denote alkaline characteristics; values lower than 7.0 indicate acid characteristics. Acid waters and excessively alkaline waters corrode metals.

In the elemental form, it is toxic. As phosphate, it is an essential plant nutrient, often being the limiting factor in plant growth.

High concentrations precipitate as hard scale in boilers, water heaters, and pipes. Inhibits deterioration of zeolite-type softeners and corrosion of iron pipes.

More than $50 \mathrm{mg} / \mathrm{L}$ may cause foaining in steam boilers. The maximum permitted for people restricted to a low salt diet is $20 \mathrm{mg} / \mathrm{L}$.

Water containing more than 1,000 my/h dissolved solids is undesirable for public and private supplies and most industrial purposes.

Relates approximately to dissolved-solids content. In the Norwalk River, 0.062 times the specific conductance is approximately equivalent to the dissolved-solids concentration.

Presence of fecal streptococci bacteria specifi cally indicates fecal waste contamination. These bacteria grow in the intestinal tract in different proportions to fecal coliform bacteria in various animals, thus they are useful in deterinining the source of fecal contamination.

Sulfates of calcium and magnesium cause perimanent hardness and form hard scale in bollers and hot water pipes. 
Temperature

Turbidity

Zine
Fluctuates seasonally in streans and shallow aquifers. At depths greater than 30 feet. ground-water temperature remains within $2^{\circ} \mathrm{C}$ or $3^{\circ} \mathrm{C}$ of mean annual air temperáture $\left[10^{\circ}\right.$ to $11^{\circ} \mathrm{C}$ for the report area (Ryder and others. 1970). Disposal of water used for cooling or industrial processing may cause local temperature anomilies.

An optical property of water attributed to suspended or colloldal matter which inhibits light penetration. May be caused by alcroorganisms, algae, suspended mineral substances including tron and manganese compounds, clay, stlt, sawdust, ftbers, or other matertals. May result from natural processes of erosion or from the addition of domestic sewage, wastes from industries such as pulp and paper manufacturing, or sediment from construction activities.

Dissolved fron rocks and ores which are slightly soluble, nore so in acid water. Chlorides and sulfates of $z$ lac are highly soluble. Also derived from industrial wastes.
Affects the usefulness of water for many purposes. For most uses, espectally cooling, water of unt formly low temperatures is desired. A rise of a few degrees in the temperature of a stream any Iimit its capacity to support aquatic ilfe. Harm water carries less oxygen in solution and is more corrosive than cold water.

Excessive concentrations are harnful or lethal to fish and other aquatic life. Turbidity is also undesirable in water used by most industries, especially in process water. Turbidity can modify water teaperature.

Toxic to various aquatic organisms. High concentrations are detrimental to some crops. 


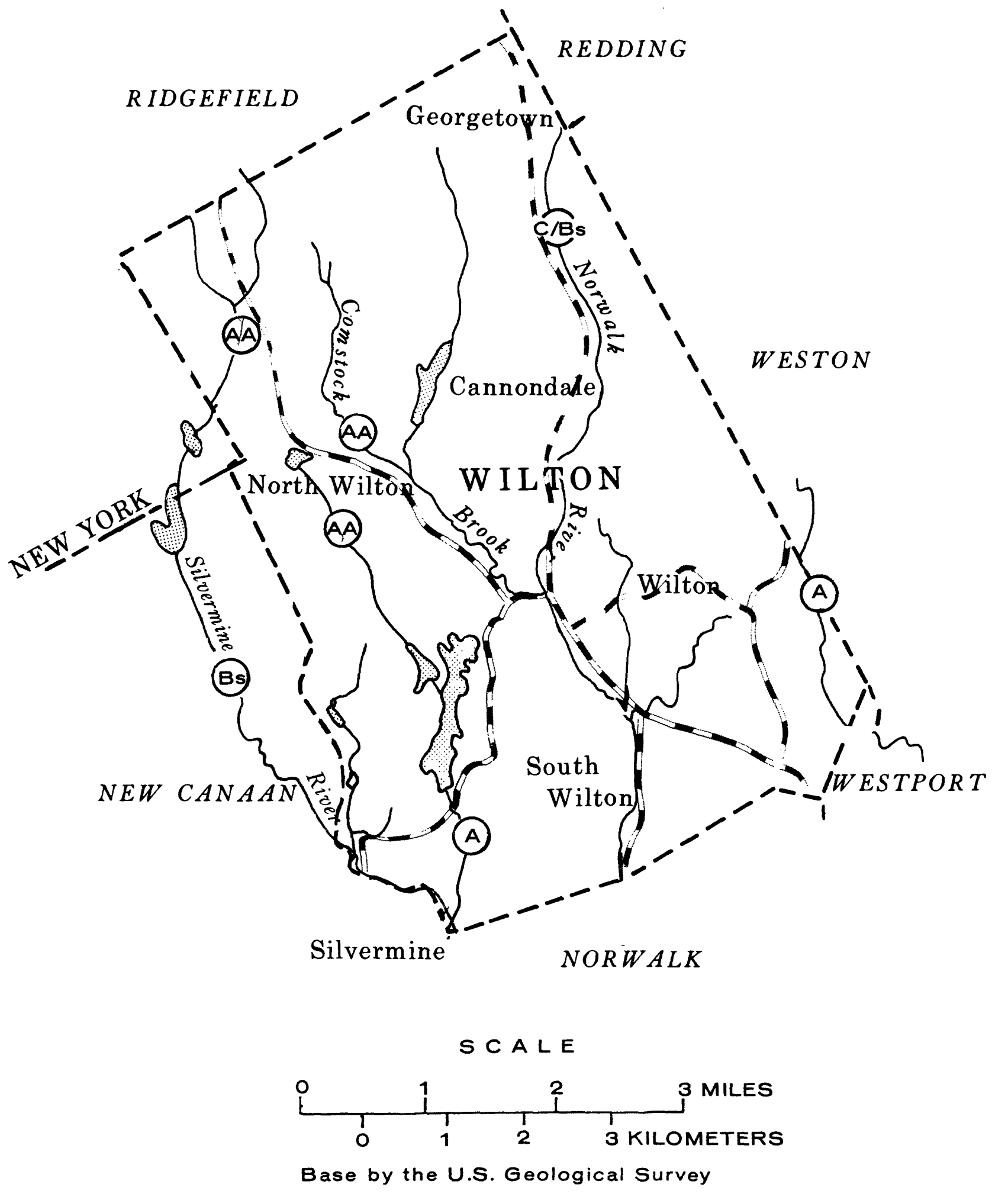

FIGURE 2.-Classification of surface waters in the study area. 
Table 5.--Classification standards for Connecticut inland waters

[Modified from Connecticut Water Quality Standards and Classifications, Connecticut Department of Environinental Protection 1977]

\section{Class AA}

Use

\begin{abstract}
Dissolved oxygen
Color and turbidity

[Jackson turbidity
\end{abstract} units (JTU)] at any time
pH

Chemical constituents

\begin{abstract}
(a) Phosphorus
\end{abstract}
(b) Sodium
Existing or proposed drinking water-supply impoundinents and tributary surface waters.

Not less than $5 \mathrm{mg} / \mathrm{L}$

Turbidity shall not exceed 10 JTU over ambient levels. A secchi disc shall be $v i s i b l e$ at a ininimum depth of 1 meter. All reasonable controls are to be used.

Not to exceed an drithuletic mean of 20 organisins/100 $\mathrm{mL}$ in any group of sainples nor shall $10 \%$ of the samples exceed 100 organisms $/ 100 \mathrm{~mL}$.

As naturally occurs.

No chemical constituents in concentrations or combinations which would be harinfu to human, animal, or aquatic life for the intended use.

None other than of natural origin.

Not to exceed $20 \mathrm{mg} / \mathrm{L}$.
Class A

May be suitable for drinking water supply and/or bathing; suit able for all other water uses; character uniformly excellent.

Not less than $5 \mathrm{mg} / \mathrm{L}$ at any time.

Turbidity shall not exceed $10 \mathrm{JTU}$ over ambient levels. A secchi disc shall be visible at a minimum depth of 1 meter. All reasonable controls are to be used.

Not to exceed an arithmetic mean of 20 organisms $/ 100 \mathrm{~mL}$ in any group of samples nor shall 10 percent of the samples exceed 100 organ isms $/ 100 \mathrm{~mL}$.

As naturally occurs.

No chemical constituents in concentrations or combinations which would be harinful to human, animal, or aquatic life for the intended use.

None other than of natural origin.
Class 8

Sultable for bathing, other recreational purposes, agricultural uses, certain indust rial processes and cooling: excellent fish and wildlife habitat; good desthe$t i c$ value.

Not less than $5 \mathrm{mg} / \mathrm{L}$ at any time.

Turbidity shall not exceed 25 JTU; a secchi disc shall be visible at a minimum depth of 1 meter.

Not to exceed a log mean of 200 organisms $/ 100 \mathrm{~mL}$ nor shall 10 percent of the samples exceed 400 organisms $/ 100$ $\mathrm{mL}$.

$$
6.5 \text { to } 8.0
$$

No chemical constituents in concentrations or combinations which would be harmful to human, animal, or aquatic life for the intended use.
$-\mathrm{Class} \mathrm{C}$

Sultable for fish and wildlife habitat, recreational boating, and certain industrial processes and cooling: good aesthetic value.

Not less than $4 \mathrm{mg} / \mathrm{L}$ at any time.

Turbidity shall not exceed 25 JTU.
Not to exceed a $l 09$ mean of 1,000 organ$1 \mathrm{sms} / 100 \mathrm{~mL}$ nor shall 10 percent of the samples exceed 2,500 organisms/100 $\mathrm{mL}$.

\section{0 to 8.5}

No chemical constituents in concentrations or combinations which would be harmful to human, animal, or aquatic life for the intended use. 


\section{Site 1}

\section{West Branch Saugatuck River Near Weston, Connecticut}

The data from this site indicate water of very good quality (table 11). The measured parameters, with the exception of fecal coliform bacteria, were within the established State standards for class A.

Alkalinity values were lower than the minimum recommended values (table 3 ) in all samples analyzed. The low alkalinity is believed to occur naturally, because of the absence of carbonate minerals in the soils and bedrock of the drainage area. The $\mathrm{pH}$ values measured do not indicate that the low alkalinity poses any problem.

In all samples, fecal coliform bacteria exceeded the criteria. The ratio, (FC/FS) of fecal coliform (FC) to fecal streptococci (FS) bacteria colonies ranged from 0.33 to 0.56 at this site. When the ratio FC/FS is less than or equal to 0.7 , and the samples were collected not more than 24 hours flow downstream from the source of pollution, it may be taken as strong evidence that the pollution derives predominately or entirely from nonhuman sources such as 1 ivestock or poultry wastes (Millipore, 1973). Wild animals such as ducks, geese, and deer would also be included in this category. Additional sampling would be necessary to determine the origin of the bacteria found at this site.

\section{Site 2}

\section{Norwalk River at Georgetown, Connecticut}

Data indicate the Norwalk River at this site to be of fair quality (tables 6 and 11 ) and has been rated class $C$ by the State (Connecticut Department of Environmental Protection, 1977). The only parameters exceeding the State standards were $\mathrm{pH}$, which was only slightly elevated on one occasion, and fecal coliform bacteria. The fecal coliform count exceeded 2,500 col/100 $\mathrm{mL}$ on several samples, but the $10 \mathrm{~g}$ mean value of all samples collected was $522 \mathrm{col} / 100 \mathrm{~mL}$, which is below the State class C standard (Connecticut Departinent of Environmental Protection, 1977)

Other physical properties and chemical constituents which were above the criteria of table 3 were color, sodium, iron, lead, manganese, methylene blue active substance (MBAS), and fecal coliform bacteria.

The most consistently high values were found for the total and fecal coliform bacteria. The FC/FS ratios associated with these bacteria counts ranged from 0.36 to 283, indicating that in many instances the bacterial contamination was possibly of human origin. A FC/FS ratio of 4 or greater is considered strong evidence that the bacterial pollution derives from human wastes, if the sample was collected not more than 24 hours flow downstream from the source of the pollution (Millipore, 1973). The source of these bacteria could be sewage 
Table 6.--Sumary of water-quality data from site 2, Norwalk River at Georgetown, Conn.

\begin{tabular}{|c|c|c|c|c|}
\hline $\begin{array}{l}\text { Chemical constituent } \\
\text { or physical property }\end{array}$ & $\begin{array}{l}\text { Number of } \\
\text { samples }\end{array}$ & Mean & $\begin{array}{l}\text { Minimum } \\
\text { value }\end{array}$ & $\begin{array}{l}\text { Maximum } \\
\text { value }\end{array}$ \\
\hline Streamflow, instantaneous $\left(\mathrm{ft}^{3} / \mathrm{s}\right)$ & 22 & 39 & 1.6 & 22.8 \\
\hline Specific conductance (umho/cm at $25^{\circ} \mathrm{C}$ ) & 22 & 289 & 165 & 490 \\
\hline $\mathrm{pH}$ (units) & 22 & 7.9 & 7.3 & 8.6 \\
\hline Temperature, air $\left({ }^{\circ} \mathrm{C}\right)$ & 22 & 14.7 & 0.0 & 30.0 \\
\hline Temperature, water $\left({ }^{\circ} \mathrm{C}\right)$ & 22 & 12.1 & 0.0 & 22.0 \\
\hline Color (platinum-cobalt units) & 19 & 24 & 3 & 65 \\
\hline Turbidity (Jackson turbidity units) & 20 & 3 & 1 & 7 \\
\hline Oxygen, dissolved (mg/L) & 21 & $11 . ?$ & 8.6 & 14.8 \\
\hline oxygen, dissolved (percent saturation) & 21 & 103 & 93 & 111 \\
\hline Coliform, total, (col./ $100 \mathrm{~mL})$ & 19 & 4,100 & 220 & 20,000 \\
\hline Coliform, fecal, (col./100 mL) & 22 & 1,000 & 56 & 4,500 \\
\hline Streptococci, fecal (col. $/ 100 \mathrm{~mL}$ ) & 22 & 480 & 3 & 3,300 \\
\hline Hardness (mg/L as $\left.\mathrm{CaCO}_{3}\right)$ & 22 & 110 & 62 & 190 \\
\hline Hardness, noncarbonate (mg/L $\left.\mathrm{CaCO}_{3}\right)$ & 22 & 44 & 13 & 110 \\
\hline Calcium, dissolved $(\mathrm{mg} / \mathrm{L}$ as $\mathrm{Ca})$ & 22 & 31 & 17 & 61 \\
\hline Magnesium, dissolved (mg/L as $\mathrm{Mg}$ ) & 22 & 7.8 & 4.7 & 12 \\
\hline Sodium, dissolved $(\mathrm{mg} / \mathrm{L}$ as $\mathrm{Na})$ & 22 & 13 & 6.9 & 22 \\
\hline Sodium adsorption ratio & 22 & 0.6 & 0.4 & 0.8 \\
\hline Bicarbonate (mg/L as $\left.\mathrm{HCO}_{3}\right)$ & 22 & 79 & 36 & 120 \\
\hline Carbonate $\left(\mathrm{mg} / \mathrm{L}\right.$ as $\left.\mathrm{CO}_{3}\right)$ & 22 & 0 & 0 & 0 \\
\hline Alkalinity $\left(\mathrm{mg} / \mathrm{L}\right.$ as $\left.\mathrm{CaCO}_{3}\right)$ & 22 & 65 & 30 & 98 \\
\hline Carbon dioxide, dissolved $\left(\mathrm{mg} / \mathrm{L}\right.$ as $\left.\mathrm{CO}_{2}\right)$ & 22 & 2.1 & 0.3 & 5.1 \\
\hline Sulfate, dissolved (mg/L as $\left.\mathrm{SO}_{4}\right)$ & 19 & 27 & 14 & 43 \\
\hline Chloride, dissolved (mg/L as Cl) & 22 & 33 & 13 & 69 \\
\hline Silica, dissolved (mg/L as $\left.\mathrm{SiO}_{2}\right)$ & 19 & 6.7 & 3.3 & 10 \\
\hline $\begin{array}{l}\text { Solids, residue at } 180^{\circ} \mathrm{C} \text {, } \\
\text { dissolved }(\mathrm{mg} / \mathrm{L})\end{array}$ & 22 & 184 & 77 & 335 \\
\hline $\begin{array}{l}\text { Solids, sum of constituents, } \\
\text { dissolved }(\mathrm{mg} / \mathrm{L})\end{array}$ & 19 & 163 & 92 & 259 \\
\hline Solids, dissolved (tons/acre-ft) & 22 & 0.25 & 0.10 & 0.46 \\
\hline Solids, dissolved (t ons/day) & 22 & 13.4 & 1.23 & 62.8 \\
\hline $\begin{array}{l}\text { solids, residue at } 105^{\circ} \mathrm{C} \\
\text { total }(\mathrm{mg} / \mathrm{L})\end{array}$ & 22 & 198 & 62 & 382 \\
\hline Nitrogen, $\mathrm{NO}_{2}+\mathrm{NO}_{3}$ total $(\mathrm{mg} / \mathrm{L}$ as $\mathrm{N})$ & 22 & 0.40 & 0.16 & 1.0 \\
\hline Nitrogen, ammonia dissolved (mg/L as $N$ ) & 21 & 0.10 & 0.00 & 0.41 \\
\hline Nitrogen, ammonia dissolved $\left(\mathrm{mg} / \mathrm{L}\right.$ as $\left.\mathrm{NH}_{4}\right)$ & 21 & 0.13 & 0.00 & 0.53 \\
\hline $\begin{array}{l}\text { Nitrogen, organic total }(\mathrm{mg} / \mathrm{L} \text { as } N) \\
\text { Nitrogen, ammonia t organic total }\end{array}$ & 21 & 0.44 & 0.17 & 1.1 \\
\hline$(\mathrm{mg} / \mathrm{L}$ as $\mathrm{N})$ & 22 & 0.53 & 0.22 & 1.3 \\
\hline Nitrogen, total (mg/L as $N)$ & 22 & 0.9 & 0.40 & 2.1 \\
\hline Nitrogen, total (mg/L as $\left.\mathrm{NO}_{3}\right)$ & 22 & 4.2 & 1.8 & 9.3 \\
\hline Phosphorus, total (mg/L as P) & 22 & 0.11 & 0.04 & 0.23 \\
\hline Copper, dissolved (ug/L as Cu) & 22 & 3 & 0 & 11 \\
\hline Iron, dissolved (ug/L as $\mathrm{Fe})$ & 22 & 180 & 40 & 390 \\
\hline Lead, dissolved (ug/L as $\mathrm{Pb}$ ) & 21 & 21 & 2 & 77 \\
\hline Manganese, dissoived (ug/L as $M n$ ) & 21 & 41 & 20 & 90 \\
\hline Zinc, dissolved (ug/L as $Z n)$ & 22 & 40 & 20 & 160 \\
\hline Carbon, organic total (mg/L as C) & 22 & 6.4 & 3.1 & 13 \\
\hline Methylene blue active substance (mg/L) & 16 & 0.08 & 0.0 & 0.90 \\
\hline Sediment, suspended (mg/L) & 22 & 23 & 3 & 336 \\
\hline Sediment discharge, suspended (tons/day) & 22 & 2.2 & 0.04 & 32 \\
\hline
\end{tabular}


treatment plant effluents, leachate from septic systems, and/or untreated drains or outfalls. The above normal concentrations of sodium, and the presence of MBAS in some of the samples, along with the concentrations of total phosphorus, total organic carbon, and chloride, also indicate the influence of sewage treatment plants and/or septic systems on the water quality at this site.

The relatively high concentrations of iron, lead, and manganese found at this site probably result from industrial waste discharges.

\section{Site 3}

Norwalk River at Cannondale, Connecticut

In general, the water quality at this site was assessed as fair (tables 7 and 11), corresponding to its State rating of class C. (Connecticut Department of Environmental Protection, 1977). The pH values exceeded the standard on two occasions and were slightly higher than those found upstream at site 2.

Fecal coliform bacteria counts exceeded the criteria in table 3 on many occasions. The FC/FS ratios frequently exceeded 4, indicative of human waste contamination. The source of the bacteria and the above normal sodium concentrations is probably sewage treatment plants and/or leachate from septic systems or outfalls, as were indicated at site 2. The levels of chloride, total phosphorus, and total organic carbon also suggest this type of source. Fecal coliform counts were similar but usually slightly lower here than at site 2 .

Iron concentrations exceeded the criteria in three samples, and lead exceeded the criteria in one sample. In general, the concentrations of all metals at this site were lower than upstream at site 2, indicating that no significant concentrations of metals are entering the river between these two sites.

\section{Site 4}

\section{Comstock Brook at North Wilton, Connecticut}

The water quality at this site was excellent (table 11) and has been classified by the State as class AA (Connecticut Department of Environmental Protection, 1977). The analytical results showed only one elevated iron concentration, and several relatively high coliform bacteria counts.

The source of the iron is uncertain, but it may be of natural origin. A large number of the total coliform bacteria do not appear to be of animal origin, based on comparison with the considerably lower fecal coliform and fecal streptococci counts. The origin of these fecal bacteria present cannot be determined by FC/FS ratios, but it is unlikely that the source is human. 
Table 7.--Summary of water-quality data from site 3, Norwalk River at Cannondale, Conn.

\begin{tabular}{|c|c|c|c|c|}
\hline $\begin{array}{l}\text { Chemical constituent } \\
\text { or physical property }\end{array}$ & $\begin{array}{l}\text { Number of } \\
\text { samples }\end{array}$ & Mean & $\begin{array}{l}\text { Minimum } \\
\text { value }\end{array}$ & $\begin{array}{l}\text { Maximum } \\
\text { value }\end{array}$ \\
\hline Streamflow, instantaneous $\left(\mathrm{ft}^{3} / \mathrm{s}\right)$ & 22 & 41 & 1.7 & 239 \\
\hline Specific conductance (umho/cm at $25^{\circ} \mathrm{C}$ ) & 22 & 281 & 165. & 440 \\
\hline $\mathrm{pH}$ (units) & 22 & 7.9 & 7.2 & 8.9 \\
\hline Temperature, air $\left({ }^{\circ} \mathrm{C}\right)$ & 22 & 15.9 & 1.0 & 30.0 \\
\hline Temperature, water $\left({ }^{\circ} \mathrm{C}\right)$ & 22 & 12.4 & 1.0 & 21.5 \\
\hline Color (platinum-cobalt units) & 19 & 17 & 0.0 & 43 \\
\hline Turbidity (Jackson turbidity units) & 20 & 3 & 1. & 7 \\
\hline oxygen, dissolved (mg/L) & 21 & 11.8 & 8.2 & 15.4 \\
\hline oxygen, dissolved (percent saturation) & 21 & 107 & 92 & 136 \\
\hline Coliform, total, (col./ $100 \mathrm{~mL})$ & 19 & 5,800 & 88 & 44,000 \\
\hline Coliform, fecal, (col./100 mL) & 22 & 890 & 19 & 3,600 \\
\hline Streptococci, fecal (col. $/ 100 \mathrm{~mL}$ ) & 22 & 3,600 & 13 & 66,000 \\
\hline Hardness $\left(\mathrm{mg} / \mathrm{L}\right.$ as $\left.\mathrm{CaCO}_{3}\right)$ & 22 & 100 & 62 & 170 \\
\hline Hardness, noncarbonate (mg/L $\left.\mathrm{CaCO}_{3}\right)$ & 22 & 43 & 13 & 87 \\
\hline Calcium, dissolved $(\mathrm{mg} / \mathrm{L}$ as $\mathrm{Ca})$ & 22 & 29 & 17 & 51 \\
\hline Magnesium, dissolved (mg/L as Mg) & 22 & 7.5 & 4.8 & 11 \\
\hline Sodium, dissolved (mg/L as $\mathrm{Na}$ ) & 22 & 13 & 4.0 & 23 \\
\hline Sodium adsorption ratio & 22 & 0.6 & 0.2 & 0.8 \\
\hline Bicarbonate (mg/L as $\left.\mathrm{HCO}_{3}\right)$ & 22 & 72 & 43 & 100 \\
\hline Carbonate $\left(\mathrm{mg} / \mathrm{L}\right.$ as $\left.\mathrm{CO}_{3}\right)$ & 22 & 0 & 0 & 0 \\
\hline Alkalinity $\left(\mathrm{mg} / \mathrm{L}\right.$ as $\left.\mathrm{CaCO}_{3}\right)$ & 22 & 59 & 35 & 82 \\
\hline Carbon dioxide, dissolved (mg/L as $\left.\mathrm{CO}_{2}\right)$ & 22 & 1.8 & 0.1 & 5.1 \\
\hline Sulfate, dissolved ( $\mathrm{mg} / \mathrm{L}$ as $\left.\mathrm{SO}_{4}\right)$ & 19 & 26 & 14 & 41 \\
\hline Chloride, dissolved (mg/L as Cl) & 22 & 32 & 13 & 61 \\
\hline Silica, dissolved (mg/L as $\left.\mathrm{SiO}_{2}\right)$ & 19 & 6.5 & 1.3 & 10 \\
\hline $\begin{array}{l}\text { Solids, residue at } 180^{\circ} \mathrm{C} \\
\text { dissolved }(\mathrm{mg} / \mathrm{L})\end{array}$ & 22 & 176 & 101 & 266 \\
\hline $\begin{array}{l}\text { Solids, sum of constituents, } \\
\text { dissolved }(\mathrm{mg} / \mathrm{L})\end{array}$ & 19 & 154 & 93 & 228 \\
\hline Solids, dissolved (tons/acre-ft) & 22 & 0.24 & 0.14 & 0.36 \\
\hline Solids, dissolved (tons/day) & 22 & 14.1 & 1.20 & 65.2 \\
\hline $\begin{array}{l}\text { Solids, residue at } 105^{\circ} \mathrm{C} \\
\text { total }(\mathrm{mg} / \mathrm{L})\end{array}$ & 22 & 192 & 121 & 321 \\
\hline Nitrogen, $\mathrm{NO}_{2}+\mathrm{NO}_{3}$ total $(\mathrm{mg} / \mathrm{L}$ as $\mathrm{N})$ & 22 & 0.41 & 0.15 & 1.0 \\
\hline Nitrogen, ammonia dissolved (mg/L as $\mathrm{N}$ ) & 21 & 0.06 & 0.01 & 0.27 \\
\hline Nitrogen, ammonia dissolved (mg/L as $\left.\mathrm{NH}_{4}\right)$ & 21 & 0.07 & 0.01 & 0.35 \\
\hline Nitrogen, organic total (mg/L as $\mathrm{N})$ & 21 & 0.47 & 0.14 & 1.6 \\
\hline $\begin{array}{l}\text { Nitrogen, ammonia + organic total } \\
(\mathrm{mg} / \mathrm{L} \text { as } \mathrm{N})\end{array}$ & 22 & 0.53 & 0.18 & 1.9 \\
\hline Nitrogen, total (mg/L as $N)$ & 22 & 0.94 & 0.47 & 2.9 \\
\hline Nitrogen, total (mg/L as $\left.\mathrm{NO}_{3}\right)$ & 22 & 4.2 & 2.1 & 13 \\
\hline Phosphorus, total (mg/L as P) & 22 & 0.11 & 0.03 & 0.31 \\
\hline Copper, dissolved (ug/L as $\mathrm{Cu}$ ) & 22 & 2 & 0 & 10 \\
\hline Iron, dissolved (ug/L as $\mathrm{Fe}$ ) & 22 & 160 & 10 & 370 \\
\hline Lead, dissolved (ug/L as $\mathrm{Pb}$ ) & 21 & 18 & 4 & 59 \\
\hline Manganese, dissolved (ug/L as Mn) & 21 & 28 & 0 & 50 \\
\hline Zinc, dissolved (ug/L as $Z n$ ) & 22 & 40 & 10 & 140 \\
\hline Carbon, organic total (mg/L as C) & 22 & 6.1 & 3.3 & 9.3 \\
\hline Methylene blue active substance (mg/L) & 16 & 0.01 & 0.00 & 0.10 \\
\hline Sediment, suspended $(\mathrm{mg} / \mathrm{L})$ & 22 & 21 & 1 & 162 \\
\hline Sediment discharge, suspended (tons/day) & 22 & 1.7 & 0.02 & 13 \\
\hline
\end{tabular}


Bryant Brook at North Wilton, Connecticut

The data collected at this site indicated excellent water quality (table 11). The State has not specifically listed this stream in its publication (Connecticut nepartment of Environmental Protection, 1977), but assesses a classification of A to all nontidal waters not listed. The data collected met class A standards with the exception of fecal coliform bacteria.

One sample exceeded the criteria of table 3 for fecal coliform bacteria. The origin of the fecal bacteria cannot be determined by FC/FS ratios. Comparisons of the total coliform counts with fecal coliform counts show that the majority of the coliform bacteria found at this site do not originate from animal waste.

On one occasion, the alkalinity value at this site was found to be lower than the criteria, however, it would require further investigation to determine whether this is a natural occurrence and the frequency of this situation. The $\mathrm{pH}$ values, which were above 7.0 , indicate that it probably does not have a significant effect on the water quality.

\section{Site 6}

\section{Norwalk River at South Wilton, Connecticut}

The Norwalk River at this site was found to have fair water quality (tables 8 and 11 ) and has been rated class $C$ by the State (Connecticut Department of Environmental Protection, 1977). Fecal coliform values were frequently above the criteria of table 3. The FC/FS ratios ranged from 0.26 to 21 , indicating that on some occasions, the bacteria were probably derived from human sources, while on other occasions, they were not. The fecal coliform counts were usually considerably lower than the total coliform counts, indicating that a substantial portion of the coliform bacteria are not derived from animal wastes. The fact that the fecal coliform bacteria counts at this site are usually less than those found at site 3 suggests that no substantial quantities of animal wastes are entering the river between these sites.

Lead concentrations on several occasions were found to be higher at this site than those found upriver at site 3 . The reasons for this, and the source of the lead is not known; however, it appears that additional lead is entering the river between these sites.

For the most part, however, the quality of water at this site is better than that found at site 3 . The data show a continuation of the trend seen between sites 2 and 3 , with a decrease in the concentrations of most constituents. 
Table 8.--Summary of water-quality data from

site 6 , Norwalk River at South Wilton, Conn.

\begin{tabular}{|c|c|c|c|c|}
\hline $\begin{array}{l}\text { Chemical constituent } \\
\text { or physical property }\end{array}$ & $\begin{array}{l}\text { Jumber of } \\
\text { samples }\end{array}$ & Mean & $\begin{array}{l}\text { Minimum } \\
\text { value }\end{array}$ & $\begin{array}{l}\text { Maximum } \\
\text { value }\end{array}$ \\
\hline Streamflow, instantaneous $\left(\mathrm{ft}^{3} / \mathrm{s}\right)$ & 22 & 68 & 3.8 & 262 \\
\hline Specific conductance (umho/cm at $25^{\circ} \mathrm{C}$ ) & 22 & 230 & 134 & 380 \\
\hline $\mathrm{pH}$ (units) & 22 & 7.7 & 7.1 & 8.5 \\
\hline Temperature, air $\left({ }^{\circ} \mathrm{C}\right)$ & 22 & 16.6 & 0.5 & 28.5 \\
\hline Temperature, water $\left({ }^{\circ} \mathrm{C}\right)$ & 22 & 12. & 1.0 & 22.0 \\
\hline Color (platinum-cobalt units) & 19 & 15 & 3 & 38 \\
\hline Turbidity (Jackson turbidity units) & 20 & 2 & 1 & 6 \\
\hline Oxygen, dissolved (mg/L) & 22 & 11.8 & 9.0 & 15.6 \\
\hline oxygen, dissolved (percent saturation) & 22 & 107 & 97 & 119 \\
\hline Coliform, total, (col./ $100 \mathrm{~mL})$ & 21 & 10,000 & 20 & 66,000 \\
\hline Coliform, fecal, (col./100 mL) & 22 & 410 & 14 & 3,100 \\
\hline Streptococci, fecal (col. $/ 100 \mathrm{~mL})$ & 22 & 420 & 6 & 3,300 \\
\hline Hardness $\left(\mathrm{mg} / \mathrm{L}\right.$ as $\left.\mathrm{CaCO}_{3}\right)$ & 22 & 75 & 23 & 98 \\
\hline Hardness, noncarbonate (mg/L $\left.\mathrm{CaCO}_{3}\right)$ & 22 & 32 & 10 & 55 \\
\hline Calcium, dissolved (mg/L as $\mathrm{Ca}$ ) & 22 & 21 & 5.8 & 28 \\
\hline Magnesium, dissolved (mg/L as Mg) & 22 & 5.6 & 1.8 & 7.5 \\
\hline Sodium, dissolved (mg/L as $\mathrm{Na})$ & 22 & 13 & 7.1 & 25 \\
\hline Sodium adsorption ratio & 22 & 0.7 & 0.4 & 1.1 \\
\hline Bicarbonate (mg/L as $\left.\mathrm{HCO}_{3}\right)$ & 22 & 52 & 16 & 69 \\
\hline Carbonate $\left(\mathrm{mg} / \mathrm{L}\right.$ as $\left.\mathrm{CO}_{3}\right)$ & 22 & 0 & 0 & 0 \\
\hline Alkalinity (mg/L as $\left.\mathrm{CaCO}_{3}\right)$ & 22 & 43 & 13 & 57 \\
\hline Carbon dioxide, dissolved (mg/L as $\left.\mathrm{CO}_{2}\right)$ & 22 & 2.2 & 0.2 & 5.2 \\
\hline Sulfate, dissolved (mg/L as $\left.\mathrm{SO}_{4}\right)$ & 19 & 21 & 7.6 & 33 \\
\hline Chloride, dissolved (mg/L as Cl) & 22 & 28 & 8.8 & 58 \\
\hline Silica, dissolved (mg/L as $\left.\mathrm{SiO}_{2}\right)$ & 19 & 7.2 & 4.0 & 10 \\
\hline $\begin{array}{l}\text { Solids, residue at } 180^{\circ} \mathrm{C} \\
\text { dissolved }(\mathrm{mg} / \mathrm{L})\end{array}$ & 22 & 139 & 59 & 208 \\
\hline $\begin{array}{l}\text { Solids, sum of constituents, } \\
\text { dissolved }(\mathrm{mg} / \mathrm{L})\end{array}$ & 19 & 122 & 47 & 181 \\
\hline Solids, dissolved (tons/acre-ft) & 22 & 0.19 & 0.08 & 0.28 \\
\hline Solids, dissolved (tons/day) & 22 & 201 & 2.12 & 65.1 \\
\hline $\begin{array}{l}\text { Solids, residue at } 105^{\circ} \mathrm{C} \text {, } \\
\text { total }(\mathrm{mg} / \mathrm{L})\end{array}$ & 22 & 155 & 55 & 237 \\
\hline Nitrogen, $\mathrm{NO}_{2}+\mathrm{NO}_{3}$ total (mg/L as $\left.\mathrm{N}\right)$ & 22 & 0.43 & 0.18 & 0.94 \\
\hline Nitrogen, ammonia dissolved (mg/L as $\mathrm{N}$ ) & 22 & 0.04 & 0.00 & 0.10 \\
\hline Nitrogen, ammonia dissolved $\left(\mathrm{mg} / \mathrm{L}\right.$ as $\left.\mathrm{NH}_{4}\right)$ & 22 & 0.05 & 0.00 & 0.13 \\
\hline Nitrogen, organic total (mg/L as $N$ ) & 22 & 0.41 & 0.07 & 1.3 \\
\hline $\begin{array}{l}\text { Nitrogen, ammonia + organic total } \\
(\mathrm{mg} / \mathrm{L} \text { as } \mathrm{N})\end{array}$ & 22 & 0.42 & 0.10 & 1.3 \\
\hline Nitrogen, total (mg/L as $N$ ) & 22 & 0.86 & 0.31 & 1.8 \\
\hline Nitrogen, total (mg/L as $\left.\mathrm{NO}_{3}\right)$ & 22 & 3.8 & 1. & 7.9 \\
\hline Phosphorus, total (mg/L as P) & 22 & 0.05 & 0.01 & 0.13 \\
\hline Copper, dissolved (ug/L as $\mathrm{Cu}$ ) & 22 & 3 & 0 & 10 \\
\hline Iron, dissolved (ug/L as Fe) & 22 & 150 & 30 & 270 \\
\hline Lead, dissolved (ug/L as Pb) & 22 & 20 & 2 & 85 \\
\hline Manganese, dissolved (ug/L as $M n$ ) & 22 & 26 & 0 & 50 \\
\hline Zinc, dissolved (ug/L as $Z n$ ) & 22 & 20 & 0 & 60 \\
\hline Carbon, organic total (mg/L as C) & 22 & 5.5 & 2.4 & 11 \\
\hline Methylene blue active substance $(\mathrm{mg} / \mathrm{L})$ & 16 & 0.01 & 0.00 & 0.10 \\
\hline Sediment, suspended (mg/L) & 22 & 30 & 1.0 & 389 \\
\hline Sediment discharge, suspended (tons/day) & 22 & 5.1 & 0.04 & 69 \\
\hline
\end{tabular}




\section{East Branch Silvermine River near Ridgefield, Connecticut}

This reach of river is rated class AA by the State (Connecticut Department of Environmental Protection, 1977), and the data collected indicated relatively good water quality (table 11).

In one sample, the fecal coliform bacteria count exceeded the State Class AA standard. However, the other fecal coliform counts were well below the standard, and fecal streptococci counts were relatively low. The FC/FS ratios associated with these counts tend to indicate a non-human source.

of note at this site were the relatively high concentrations of manganese found in all three samples collected. Further investigation would be necessary to determine the exact source, but it is possible that it occurs naturally as a result of the mineral content of the rocks and soils of the drainage basin.

Dther values found were within the suggested and established criteria and were not indicative of any significant contamination.

\section{$\underline{\text { Site } 8}$}

\section{East Branch Silvermine River near North Wilton, Connecticut}

The State has rated this reach of the river as class AA (Connecticut Department of Environmental Protection, 1977), and the data collected indicate very good water quality (table 11). Although one total coliform count was relatively high, the fecal coliform and fecal streptococci counts were generally low, indicating that at the time of sampling, fecal waste contamination was insignificant.

Values for nearly all parameters measured at this site showed an improvement in water quality over that found at site 7. A possible exception was MBAS, which was detected in two out of the three samples collected at this site, and was not found in any samples collected at site 7 . Although the concentrations of MBAS were well below the water-quality criteria (table 3 ), its presence could be significant, representing natural organic acid complexes or some type of foaming agents that could be entering the river between this site and site 7 . 
Thayers Brook near Silvermine, Connecticut

This stream has not been specifically classified by the State (Connecticut Department of Environmental Protection, 1977), hut was assumed to be class A, as was the case with Bryant Brook (site 5). The data collected indicated water of good quality (table 11).

Total coliform bacteria counts ranged from 50 to $1400 \mathrm{col} / 100 \mathrm{~mL}$. The fecal coliform counts were considerably lower by comparison, indicating that the majority of the coliform bacteria did not come from fecal material. In two of three samples, fecal coliform counts exceeded 20, however, the FC/FS ratio associated with the highest bacteria counts measured (May 12, 1976) was 0.51 , indicating that the probable sources of these fecal bacteria were some warm-blooded animals other than humans. Because the numbers of these bacteria were relatively low, it is possible that they originated from the natural populations of birds and mammals in the area.

The $\mathrm{pH}$ values at this site were consistently lower than those found at any other site in the study area. The samples on all three occasions also had low alkalinity values. These low values may be partly due to the geologic materials in the basin that affect the chemical characteristics of ground-water contributions to streamflow, and/or organic decomposition and other biological activity occurring in the pond just upstream of the sample site (fig. 1).

Some iron and manganese concentrations were also above the criteria. The source of these constituents is also probably related to the geologic material of the basin, and/or biological activity in the pond.

\section{Site 10}

\section{Silvermine River near Silvermine, Connecticut}

The State has classified this reach of the river as class $B$ (Connecticut Department of Environmental Protection, 1977), and the data collected in this investigation are indicative of good water quality (table 11).

Values for most parameters analyzed at this site showed an improvement in the quality of the water from that which was found in the East Branch of the river at sites 7 and 8.

One relatively high total coliform count was found $(2000 \mathrm{col} / 100 \mathrm{~mL})$, with a corresponding fecal coliform count of $330 \mathrm{col} / 100 \mathrm{~mL}$. The FC/FS ratio for this sample (May 12, 1976) was 0.69, indicating that the source of the fecal bacteria was probably not human waste.

Slightly below criteria alkalinity values were found at this site on two of the three samples collected, but it does not appear to he a significant factor in the overall quality of the stream, based on $\mathrm{pH}$ values. 
Bottom materials have a significant role in the water quality of a stream for several reasons. Of primary importance is the fact that many chemical constituents of water can be sorbed onto these bottom sediments, and in effect, they act as a sink for them. These chemicals can then be transported with the sediments either by chemical, physical, and biological processes. It is also possible for some of these chemicals to be brought back into solution. Thus, bottom materials can be thought of as an indicator of the chemicals that have been in the water, as a transport mechanism for the chemicals, and as a potential source of these chemicals at a future time.

Bottom material samples were collected at sites 2, 3, and 4 in June of 1976 (table 9). Values from Comstock Brook at site 4 were used to reflect natural conditions in the area based on land use in its hasin; therefore, the levels of aluminum, copper, and iron appear to be elevated at Norwalk River sites 2 and 3 . Comparison of data between these two sites indicates that metal concentrations are higher at site 3 than at site 2.

Because of the mobility of bottom materials, and the lack of information concerning their rate of transport in the river, it is not possible to determine where the metals originated in the basin. More detailed sampling over an extended period of time would be necessary to determine whether these materials are actually entering the river between sites 2 and 3 .

Low concentrations of the pesticides DDE and DDT, and a rather high concentration of chlordane $(45 \mathrm{ug} / \mathrm{kg})$ were also found in the sample from Comstock Brook (site 4), indicating that these substances were used in the basin at some time in the past.

\section{Biological Studies}

The diversity of the biological community found in a body of water is a good indication of the relative water quality. In general, water of good quality will support a wide variety of organisms, with relatively small numbers of each type of organism present. On the other hand, water of poor quality usually supports a rather sparse variety of organisms, with those that are tolerant of the poor quality being present in large numbers.

Data for biological analysis were collected at sites 2, 3, and 4 from October 1975 to June 1976 (table 10).

Samples of phytoplankton populations in the Norwalk River (sites 2 and 3 ) showed good diversity, indicative of rather good water quality. There was less diversity of phytoplankton in Comstock Brook (site 4); however, the population was made up entirely of various species of diatoms. Diatoms are usually indicative of good water quality, and the lack of green or blue-green algae would tend to indicate a deficiency of some plant nutrient as the limiting factor for diversity at this site. Data for algal growth potential and total phytoplankton cells found at sites 2 and 3 were considerably higher that at site 4 . 
Benthic invertebrates possess several characteristics that make them valuable indicators of water quality. Because of their limited mobility and relatively long life span, populations of these bottom dwelling animals reflect water-quality conditions over a long period of time, not just at the instant of sample collection. Information is also available concerning the specific waterquality conditions under which various types of these organisms can exist. Thus, the absence or presence of certain types of benthic invertebrates is indicative of specific water-quality conditions.

Benthic invertebrate populations in the Norwalk River at sites 2 and 3 showed relatively good diversity, which is indicative of good quality. However, the predominant types of organisms present would be characterized as those which are relatively tolerant to pollutants, such as midges and caddis flies. The diversity of benthic invertebrates at site 4 in Comstock Brook was less than that at the Norwalk River sites, possibly due to a limited amount of available food or habitat. The chlordane concentrations found in the bed sample at this site could also be indicative of a condition that existed in the past, which may explain the lesser diversity at this site. Considerably more data would be necessary to determine if this were the case. The types of benthic invertebrates found at this site included several species of mayflies, which are considered to be intolerant of pollution as a group and indicative of good water quality.

\section{SIIMMARY}

The data collected indicate that streams in the Town of Wilton, Connecticut had fair to excellent water quality. The parameters which most often exceeded recommended and established criteria (table 3) were fecal coliform bacteria, $\mathrm{pH}$, alkalinity, manganese, and iron.

The total coliform bacteria population in most instances appear to be composed primarily of types that are not derived from fecal material. When fecal coliform bacteria counts were found to exceed the criteria, the origins of these bacteria, based on FC/FS ratios, were usually not related to human waste. The exceptions are sites 2, 3, and 6 on the Norwalk River, which had FC/FS ratios indicative of human waste contamination on several occasions.

The Norwalk River showed improvement in water quality as it flowed through wilton. The concentrations of most chemical constituents and bacteria decreased from the Georgetown site to the Cannondale site. Data from the South Wilton site showed a continuation of this trend of improved quality, with some exceptions, most notably lead, which appears to be entering the river between the Cannondale and South Wilton sites.

In general, the East Branch Silvermine River had better water quality than that of the Norwalk River. The data showed that the quality of the Silvermine River also improved as it flowed through Wilton. Nearly all parameters showed decreases in concentration between the Ridgefield and the North Wilton sites, with the exception of the methylene blue active substance. This substance was present in low concentration at the North Wilton site, and absent upstream at Ridgefield. Data from further downriver at Silvermine, on the main stem of the Silvermine River, showed more improvement in water quality. 
Bottom material analysis from the Norwalk River (sites 2 and 3) and Comstock Brook (site 4) showed concentrations of some metals in the Norwalk River above those expected under normal conditions. The Comstock Brook sample had no abnormal concentrations of metals, but did contain a high concentration of chlordane, and trace concentrations of DDE and DNT.

Biological samples collected at sites 2,3 , and 4 indicated relatively good water quality. In general, the types of organisms found in the Norwalk River were indicative of higher concentrations of nutrients, and were of types that are more tolerant to degraded water quality than those found in Comstock Brook. 
Table 9.--Bottom material analyses

Site 2, Norwalk River at Georgetown, Conn.

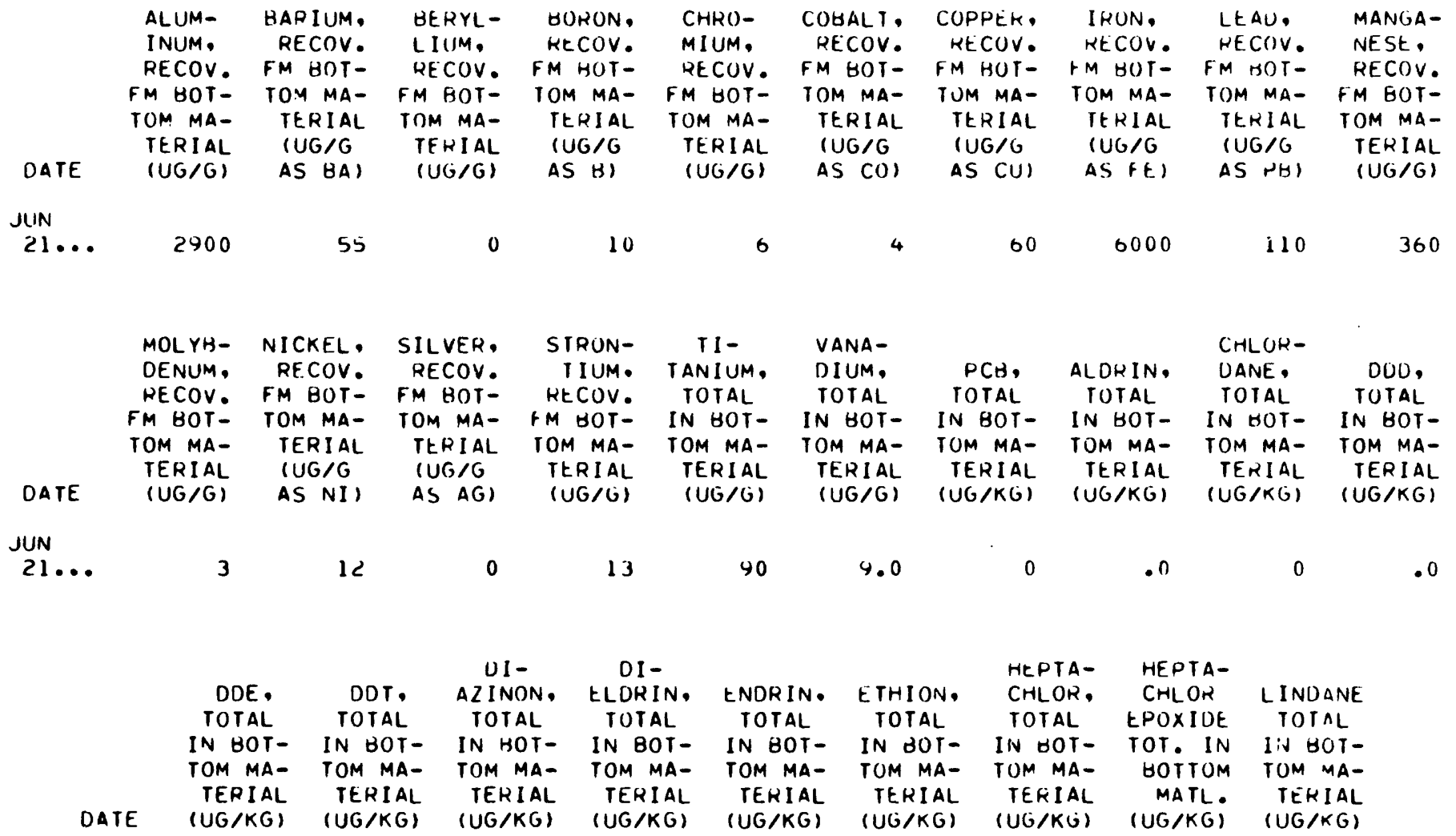

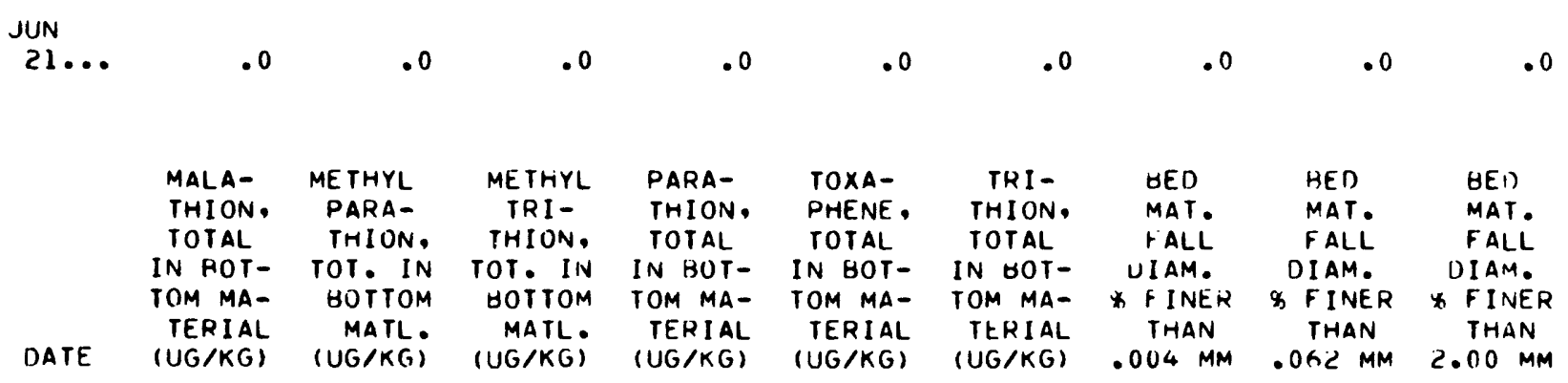

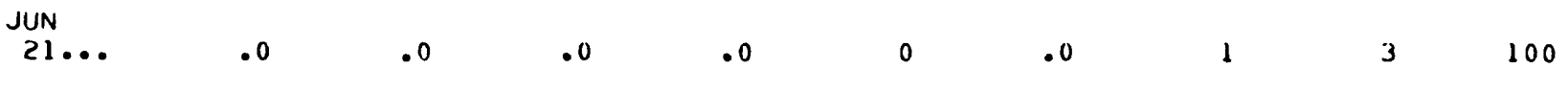




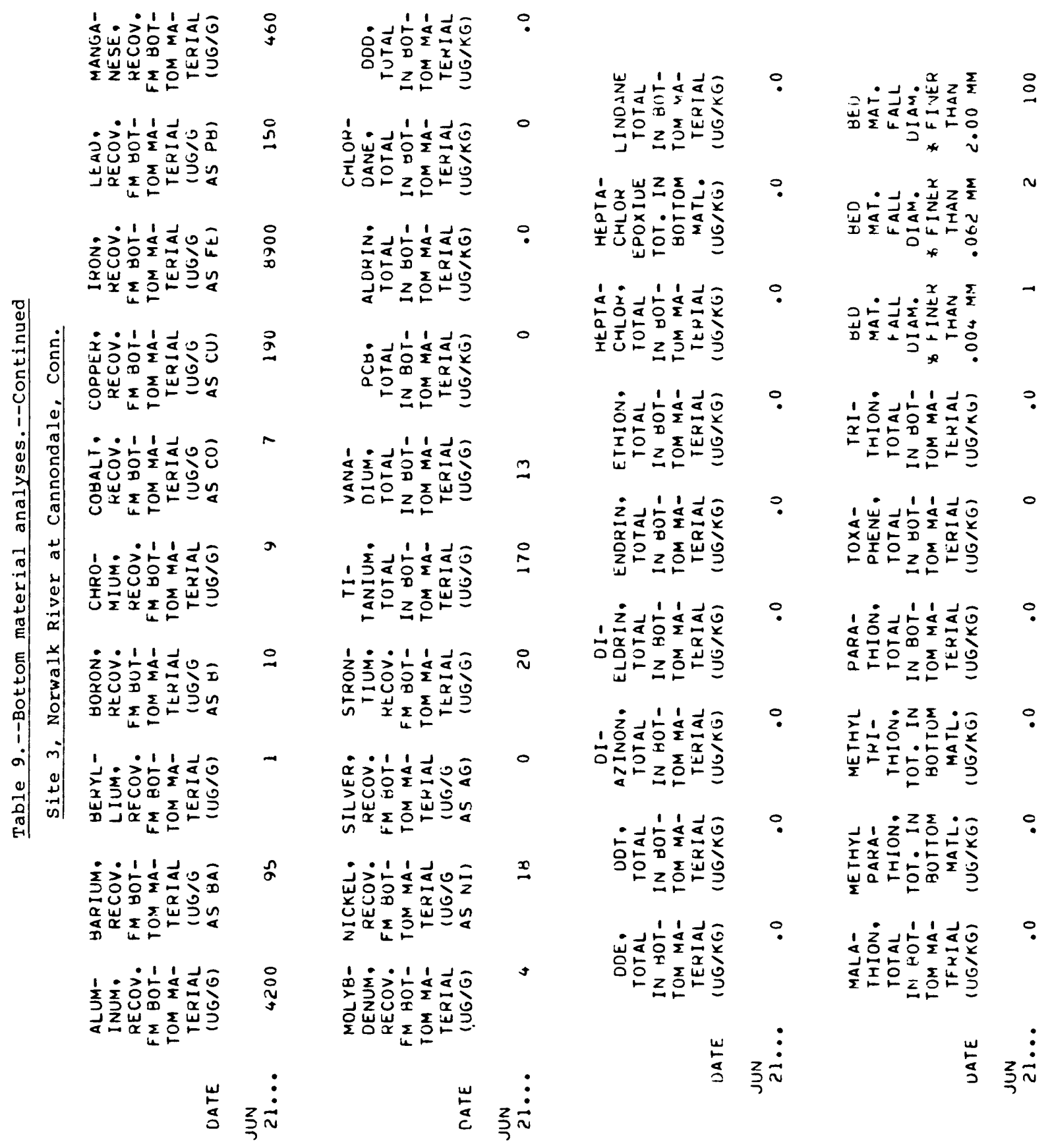




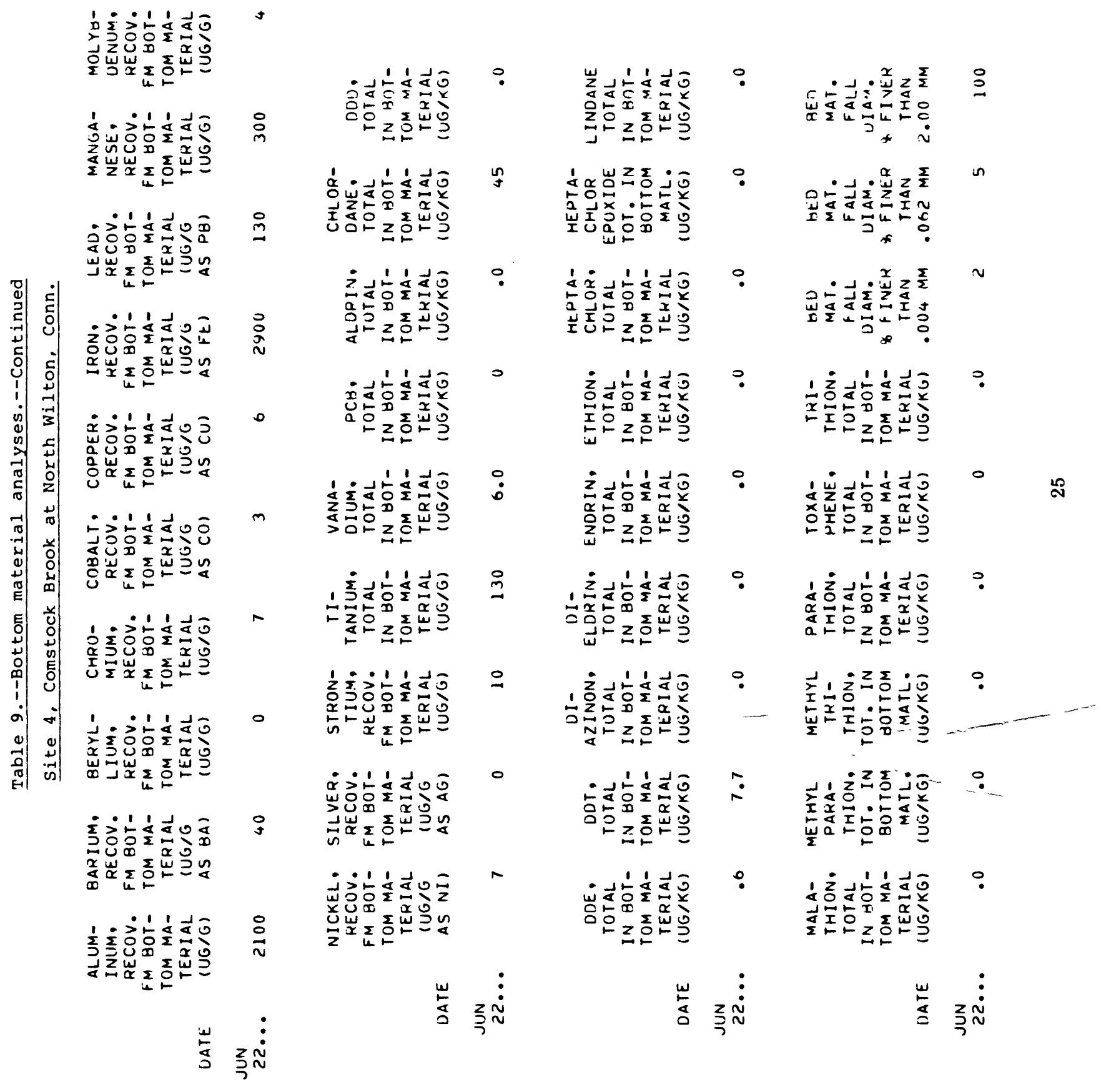




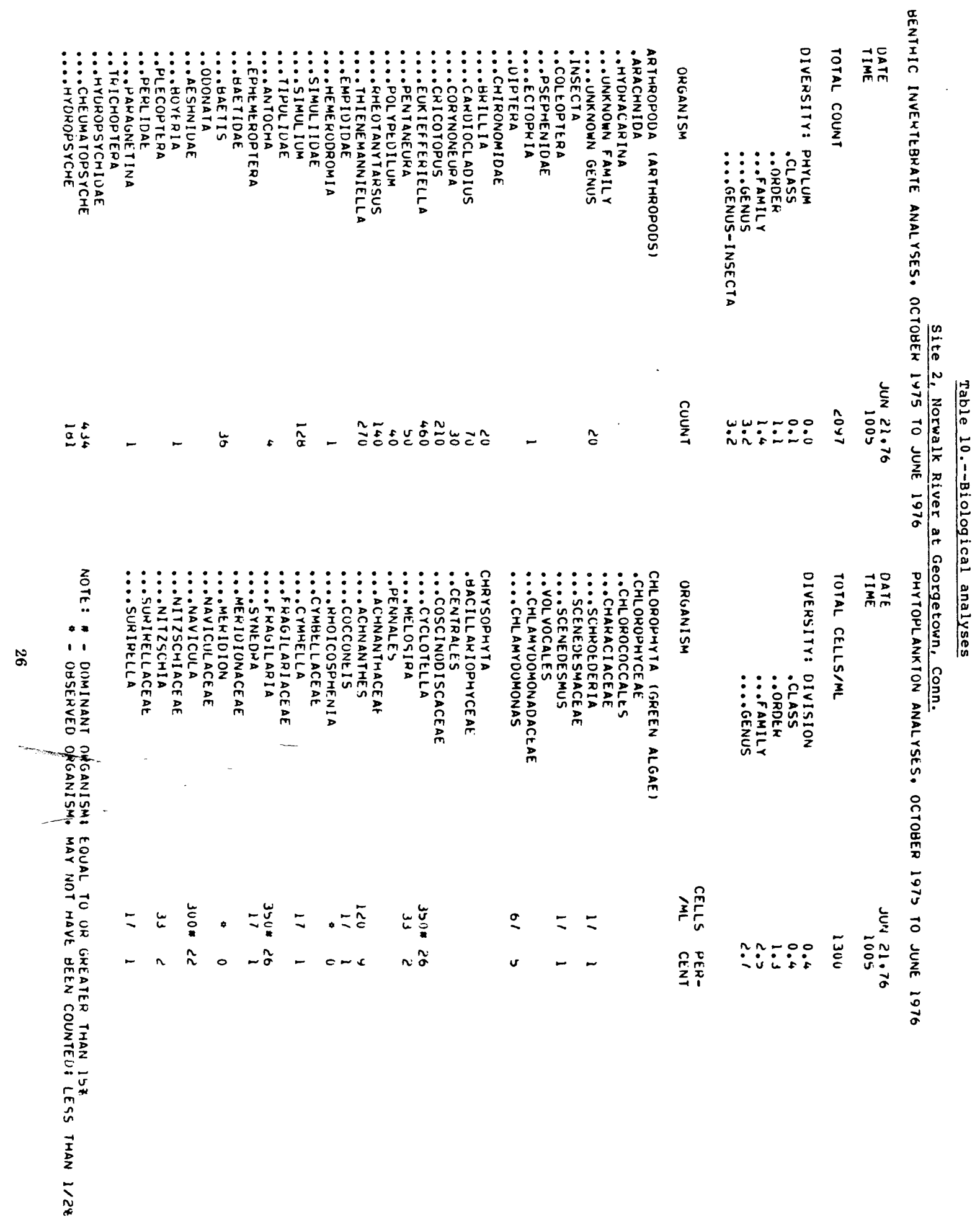




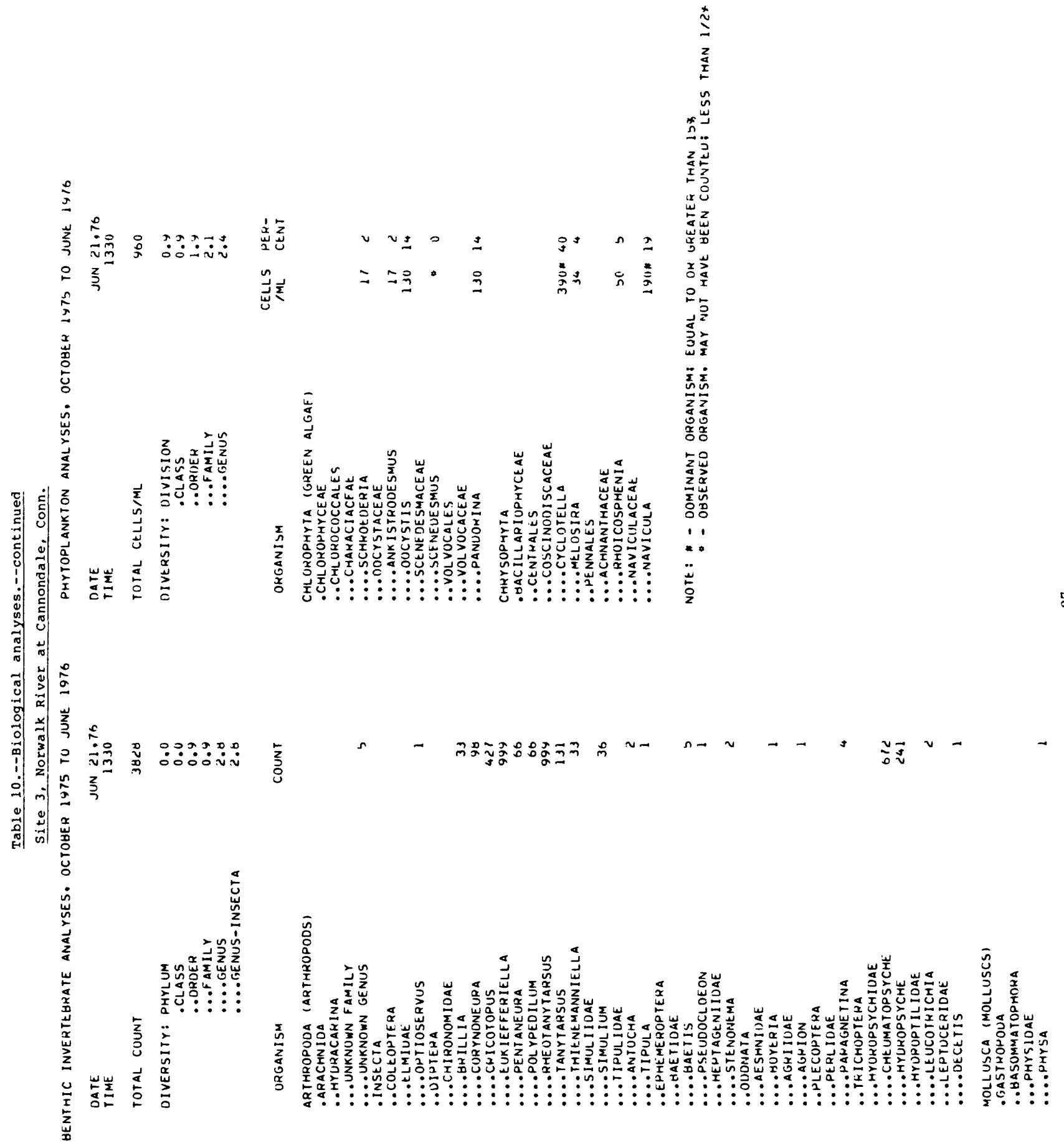




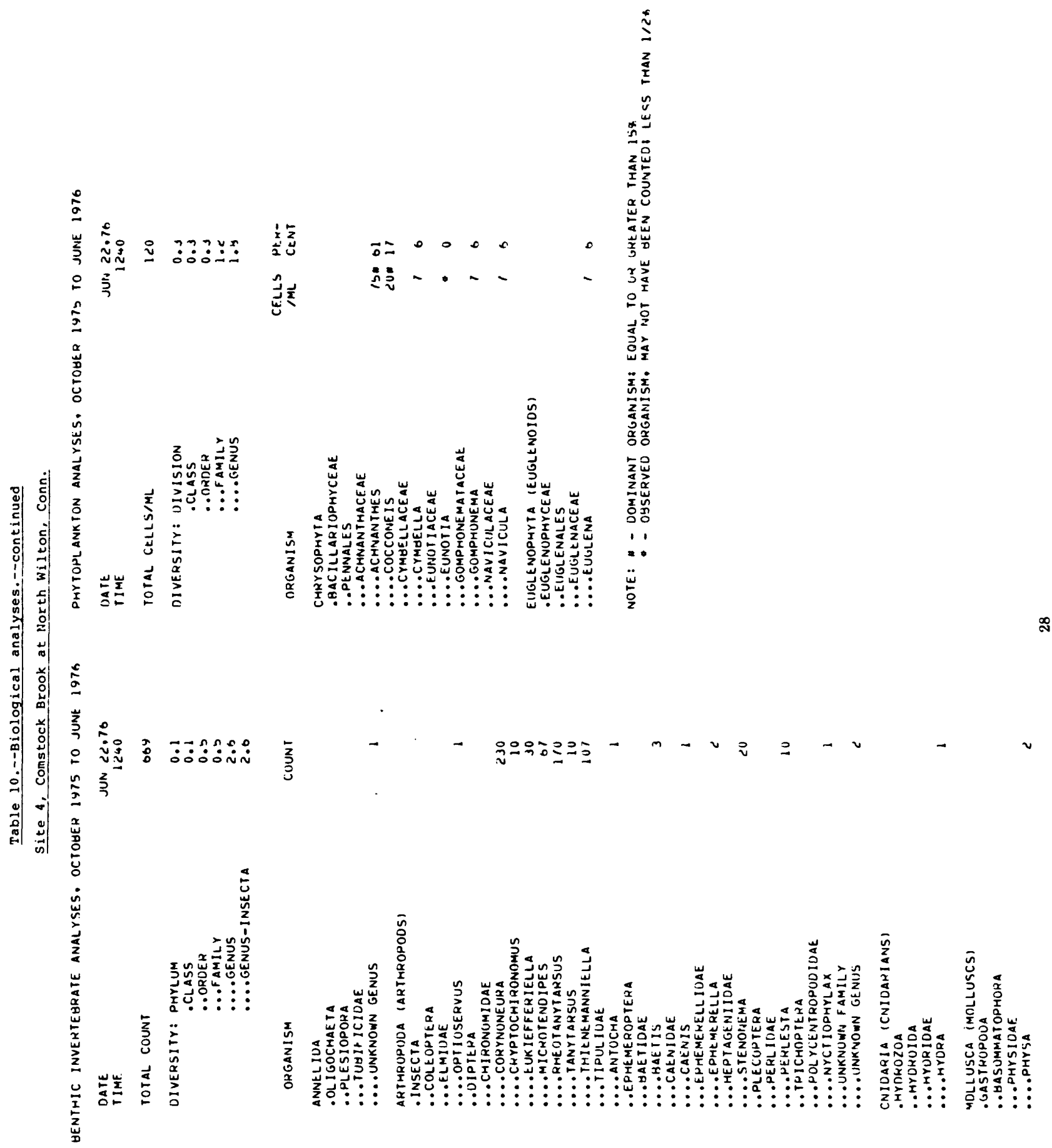




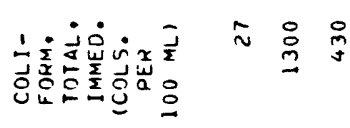

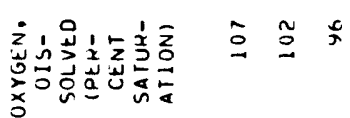

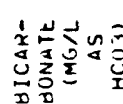

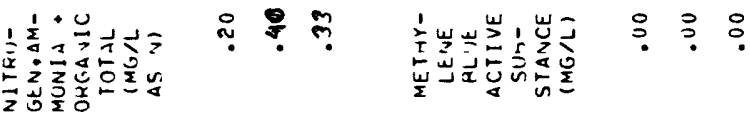

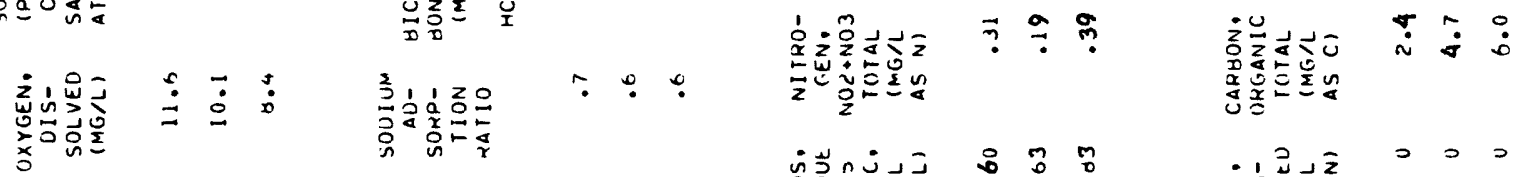

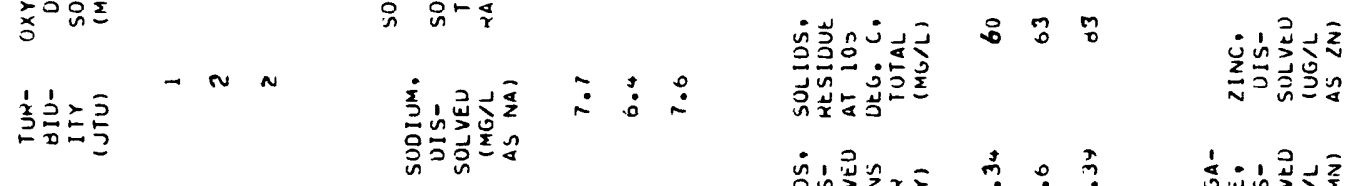

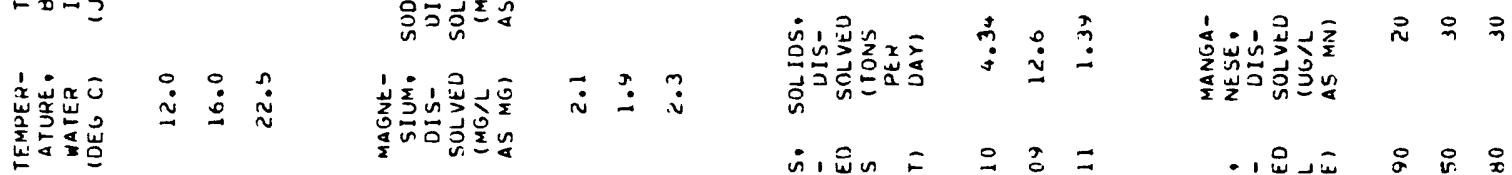

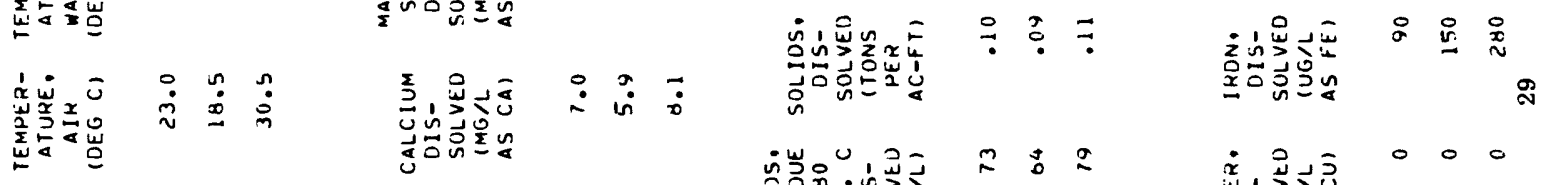

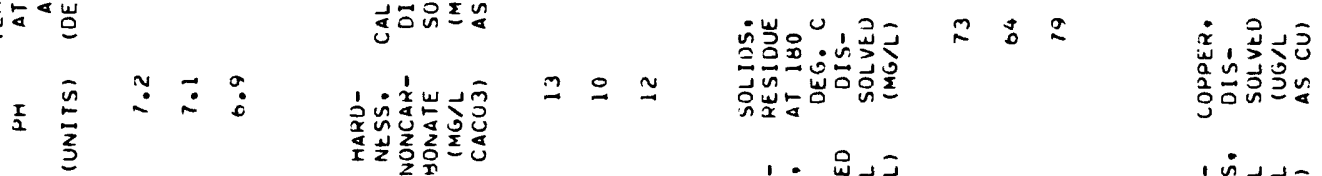

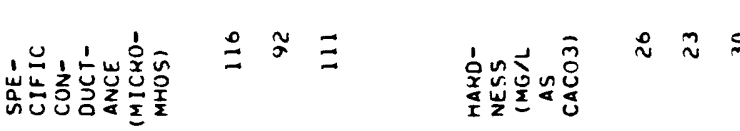

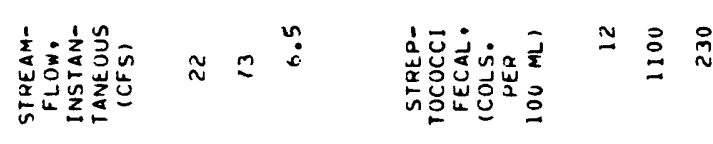

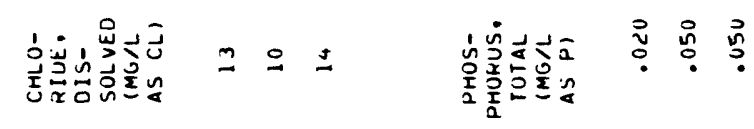

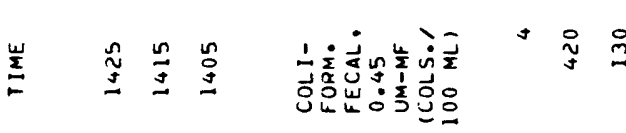

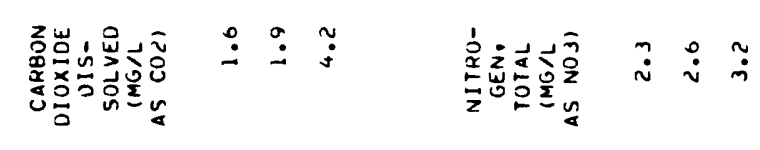

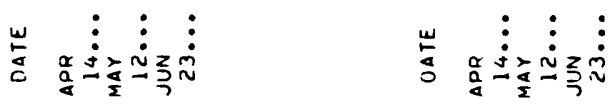

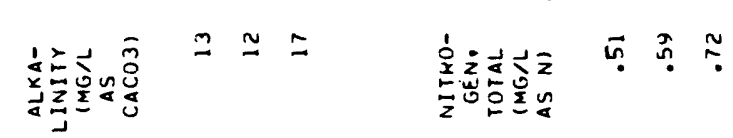

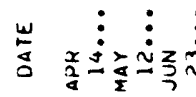

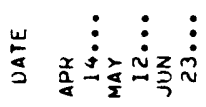




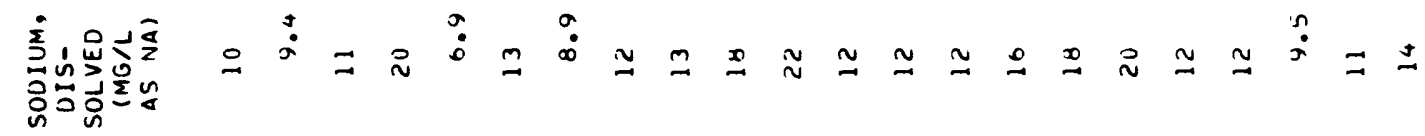

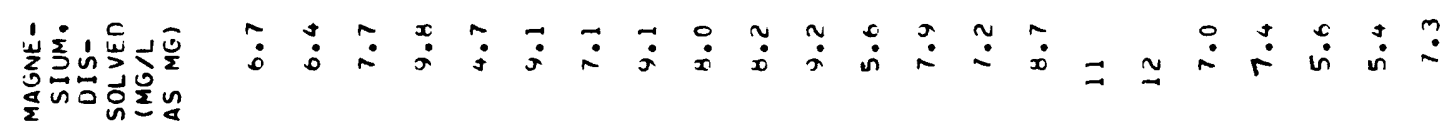

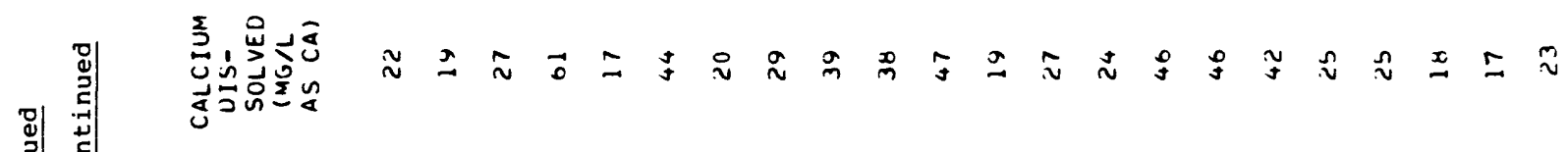

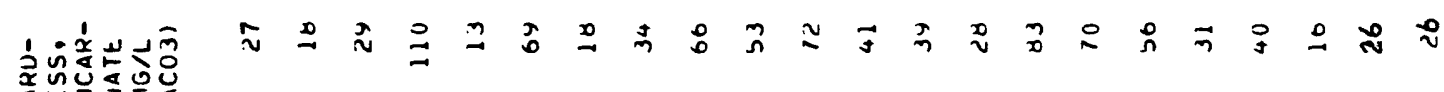

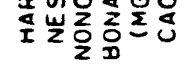

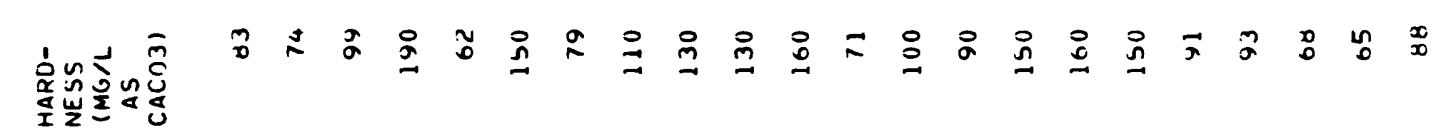

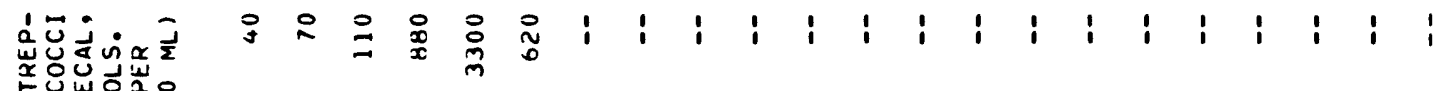

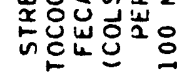

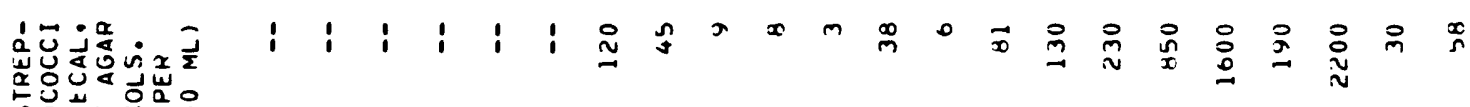

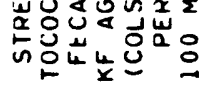

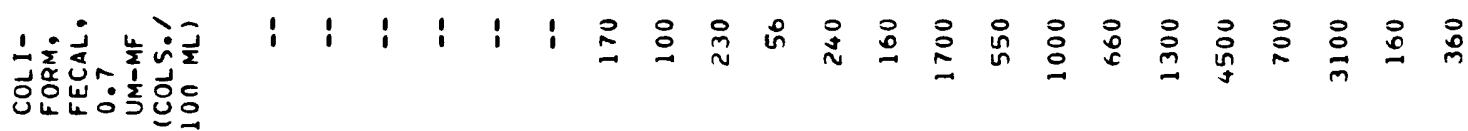

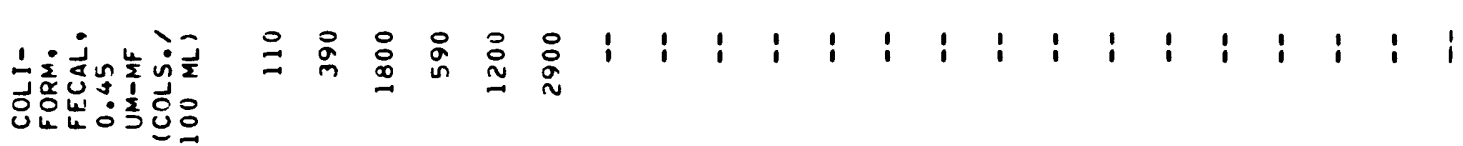

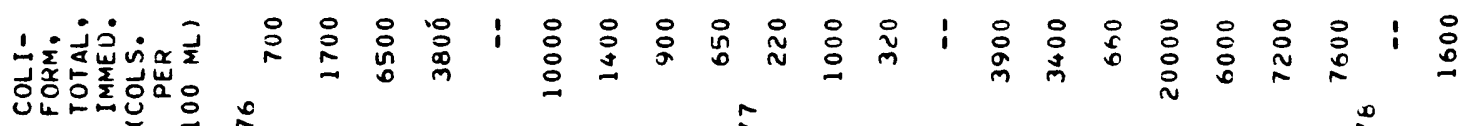

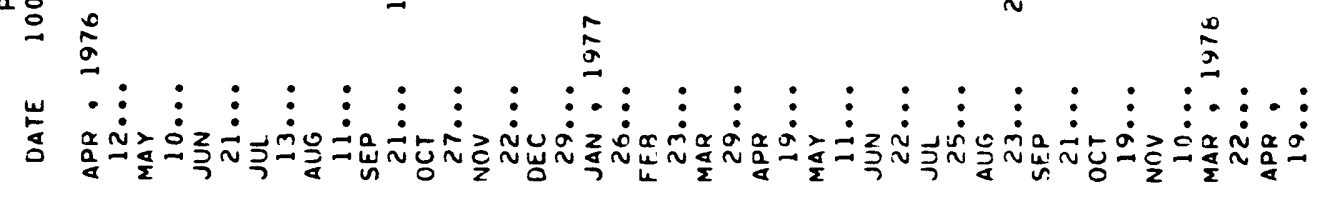




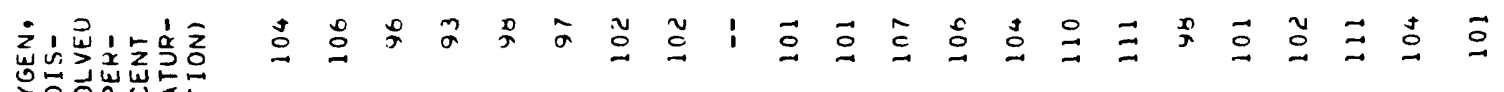

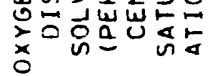

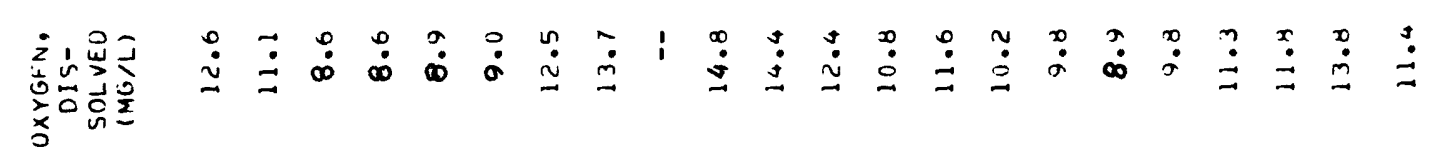

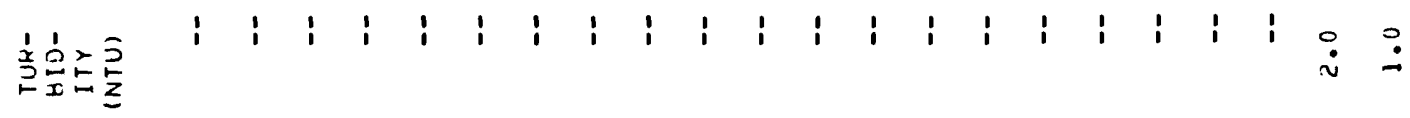

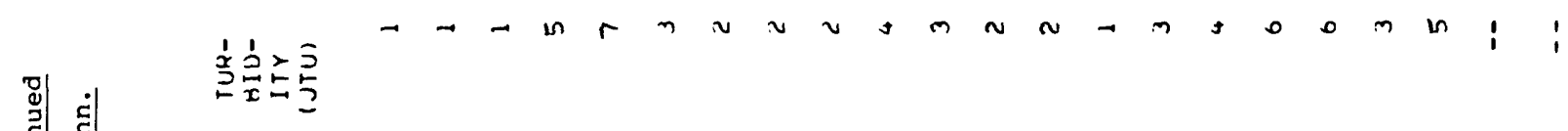

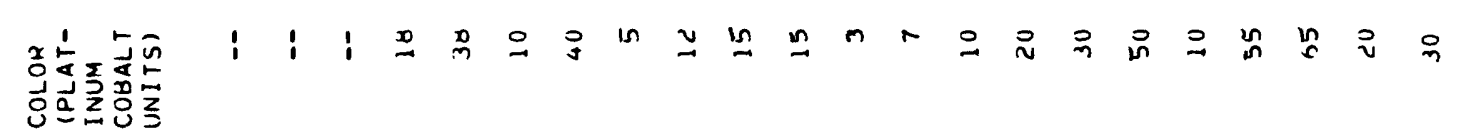

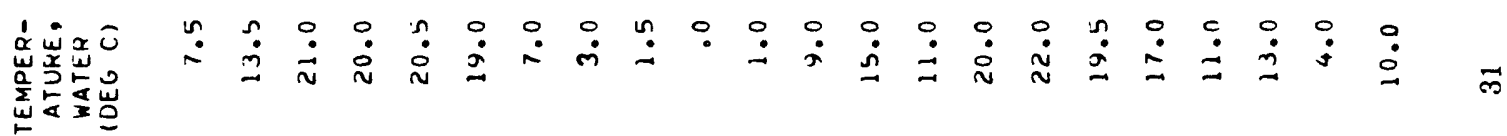

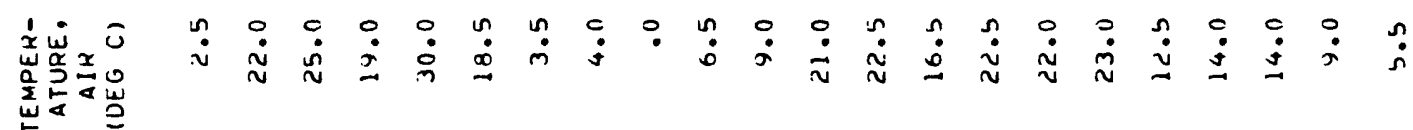

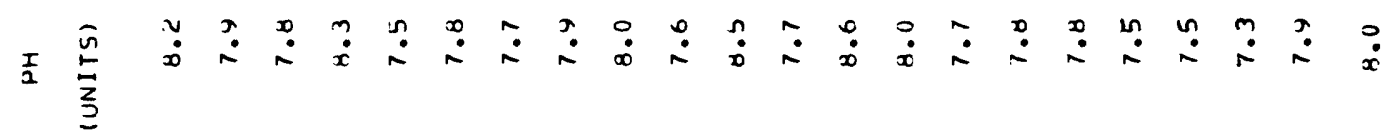

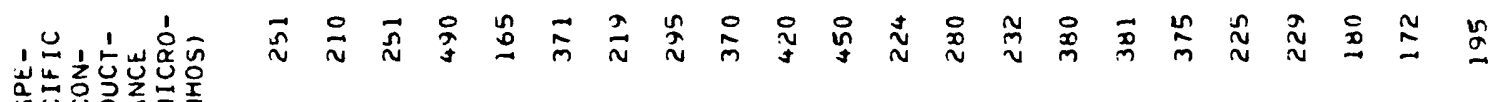

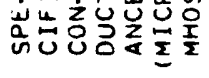

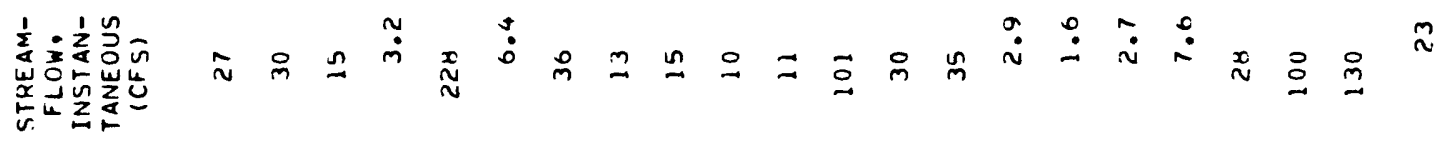

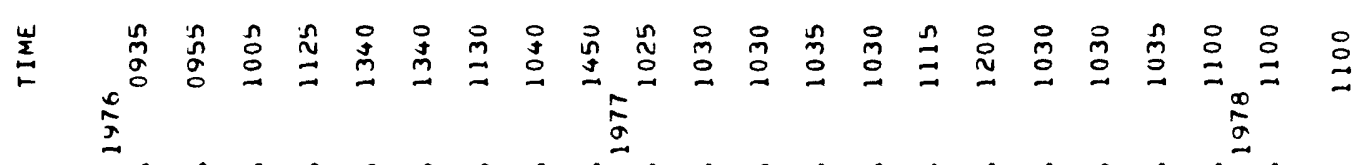

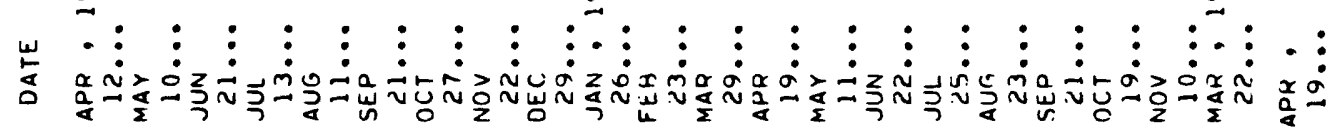




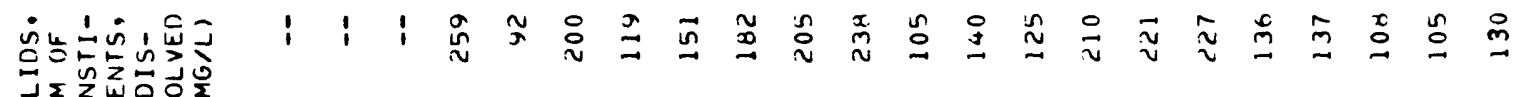

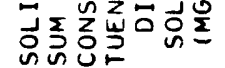

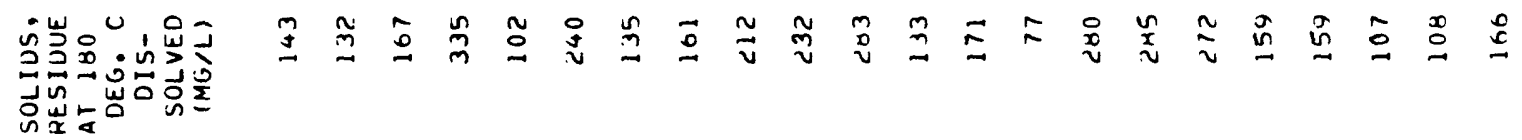

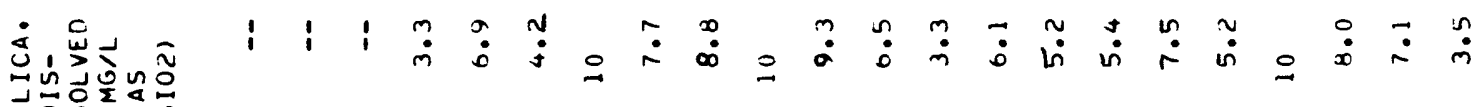

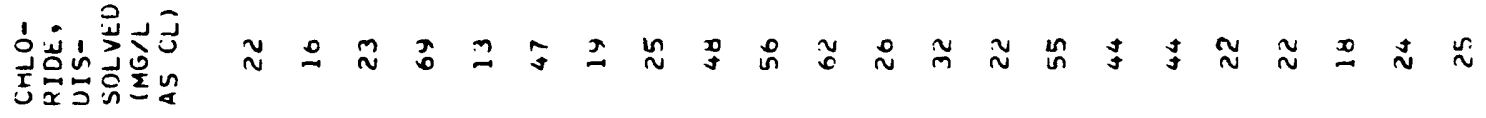

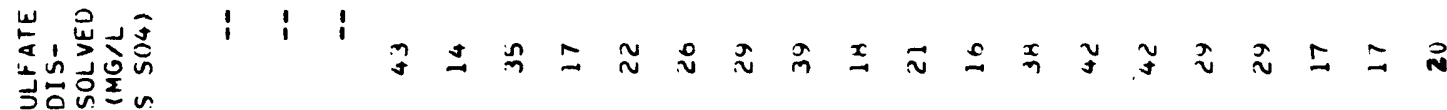

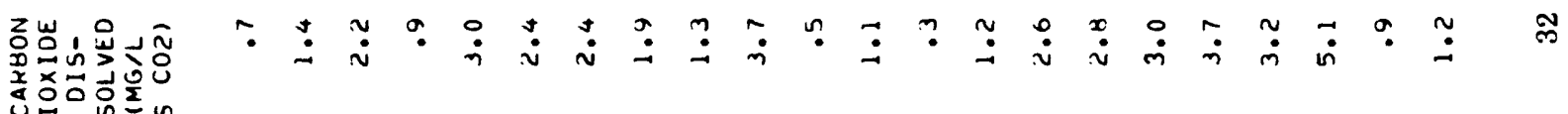

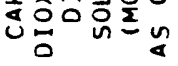

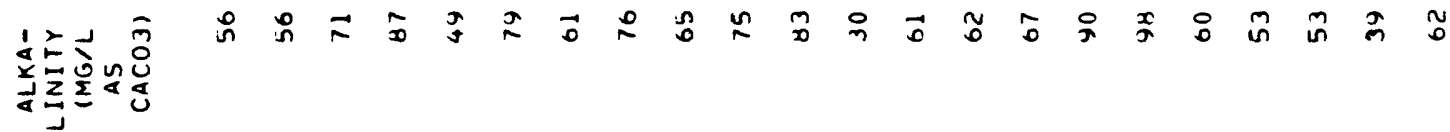

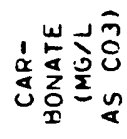

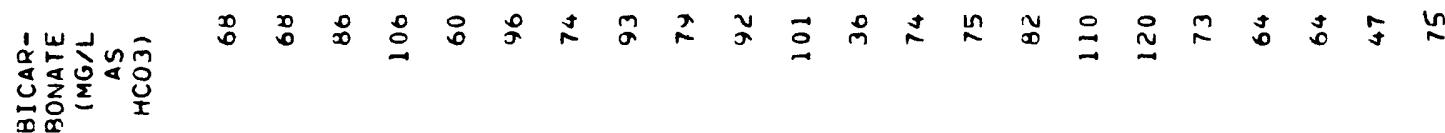

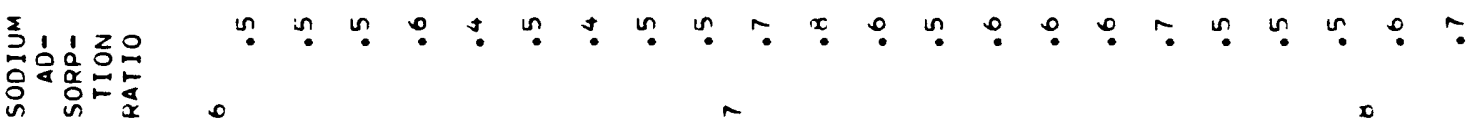

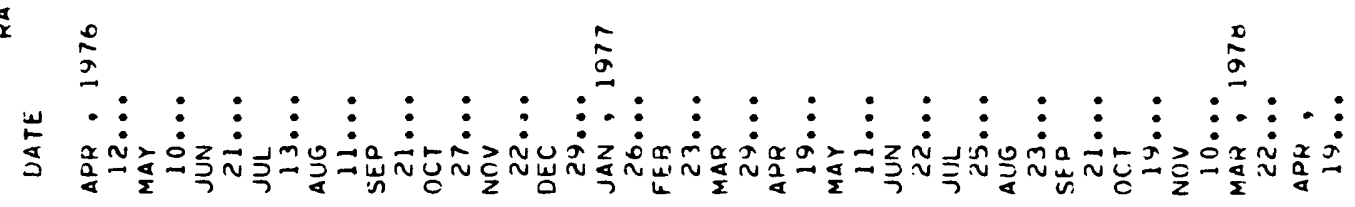




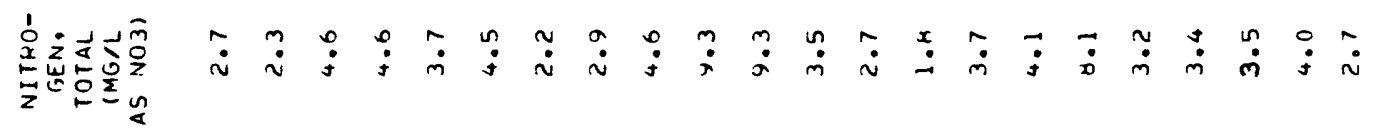

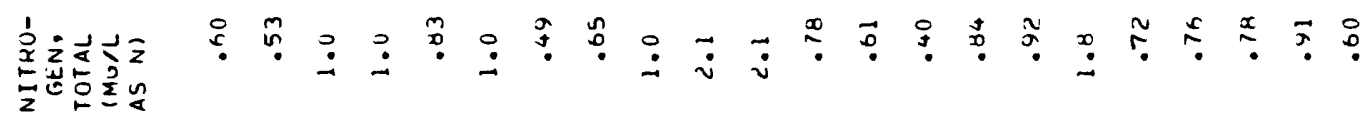

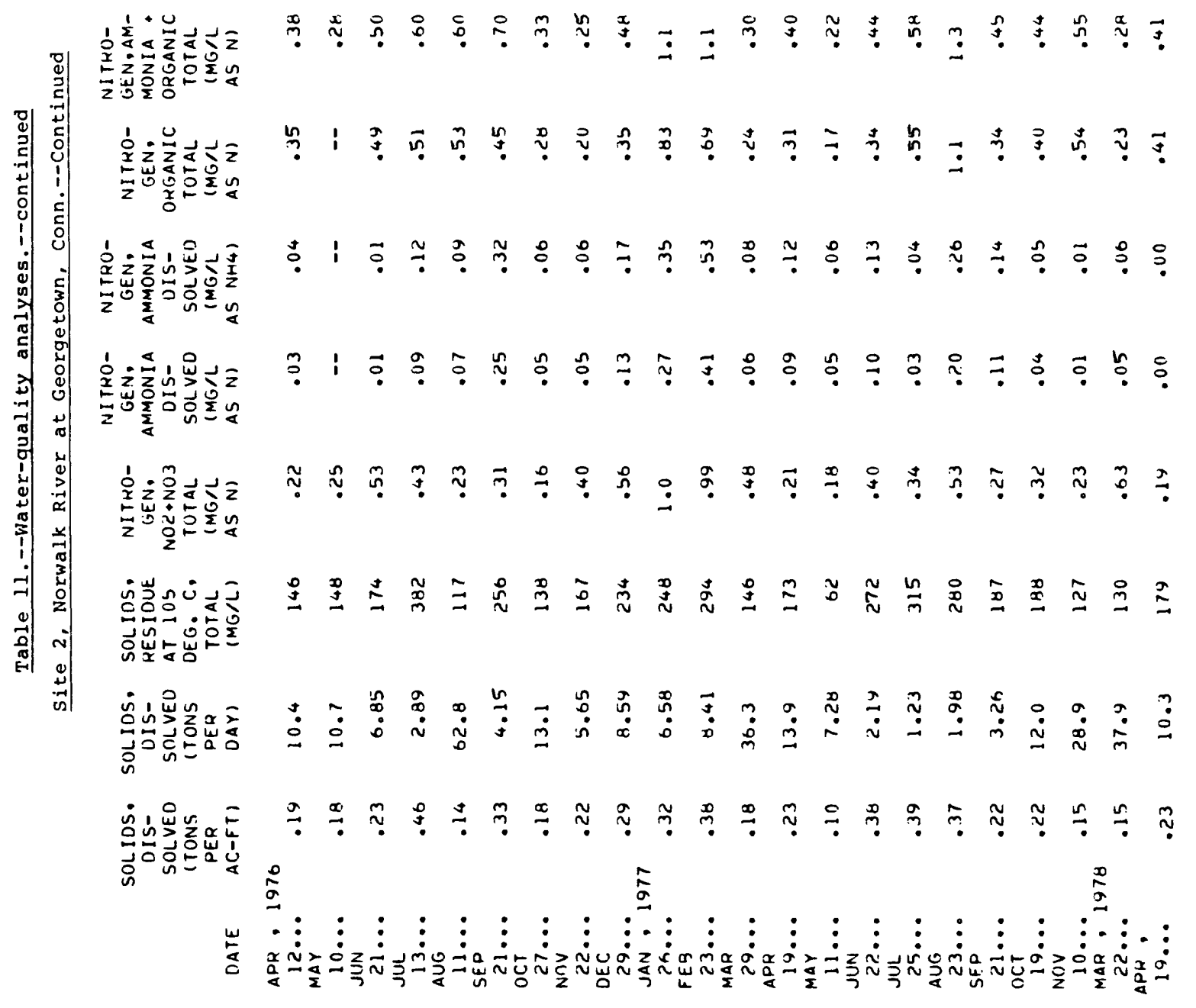




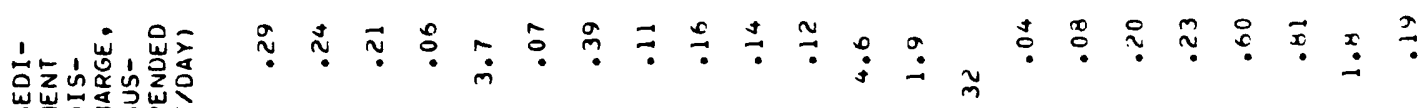

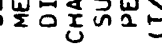

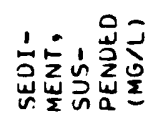

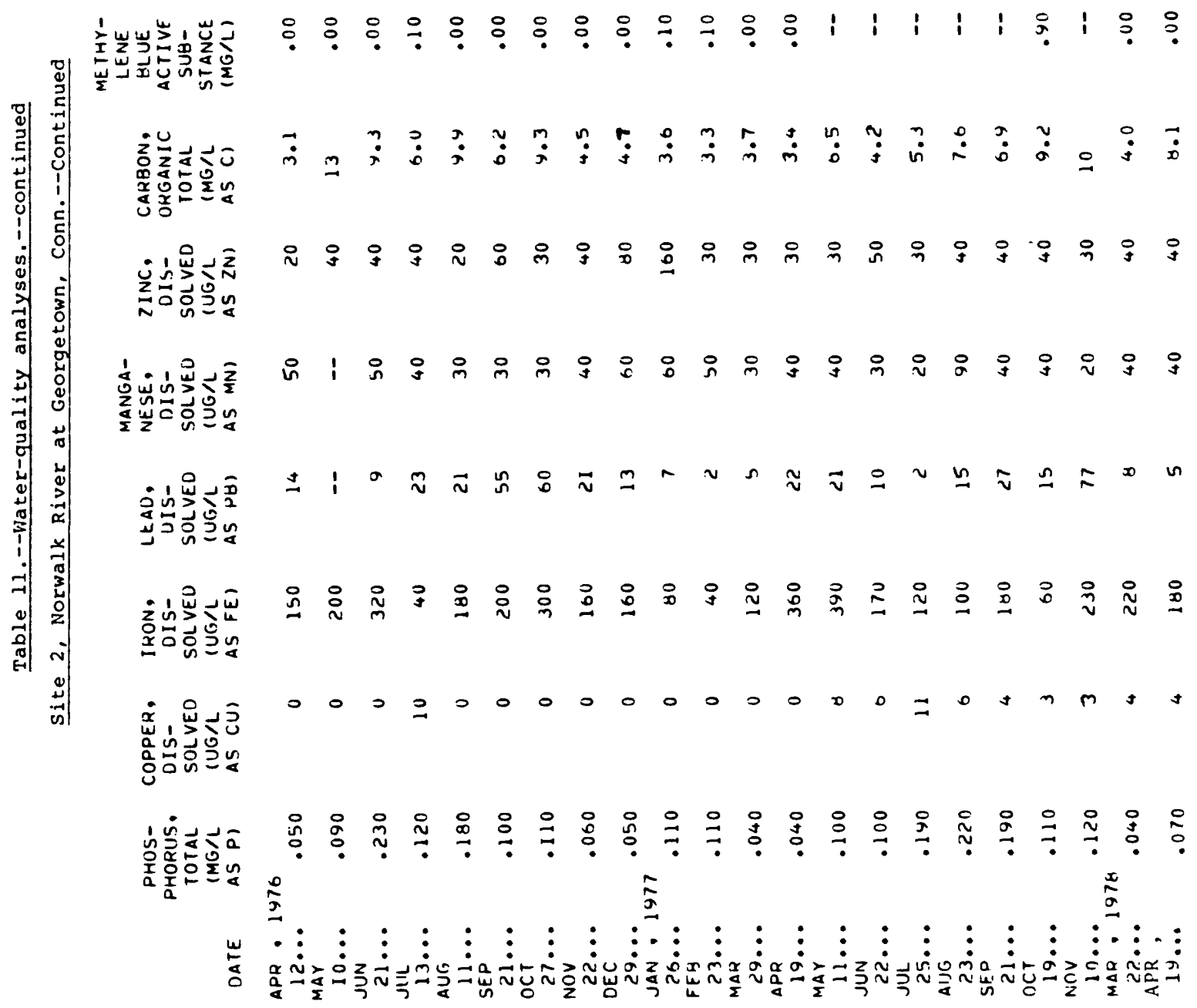




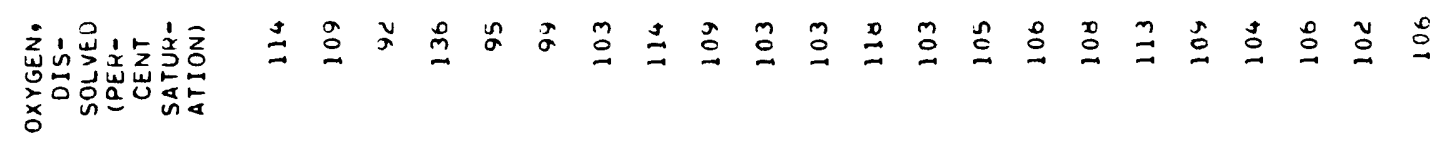

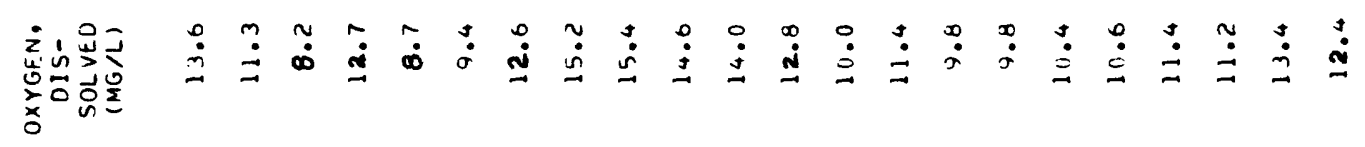

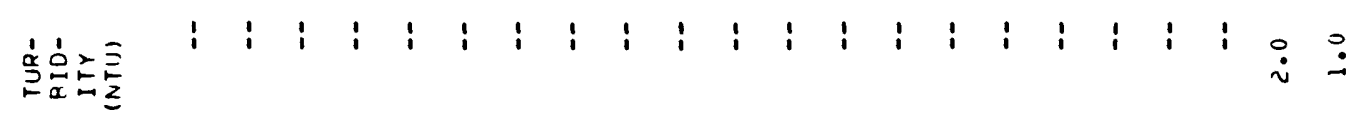

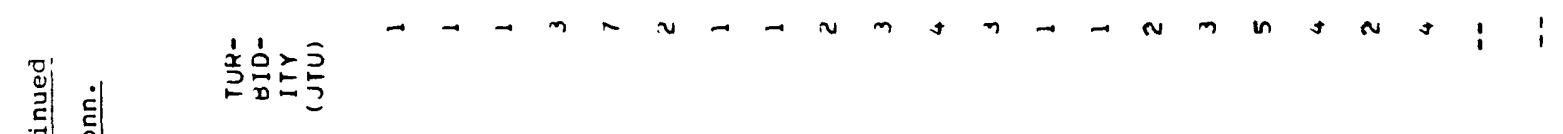

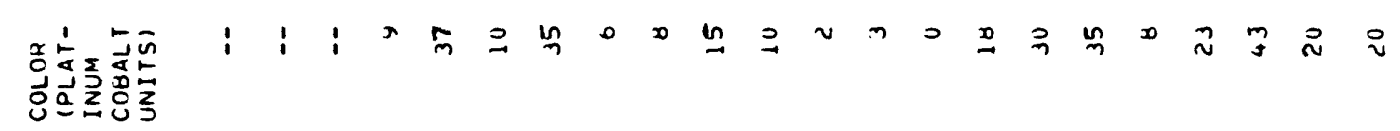

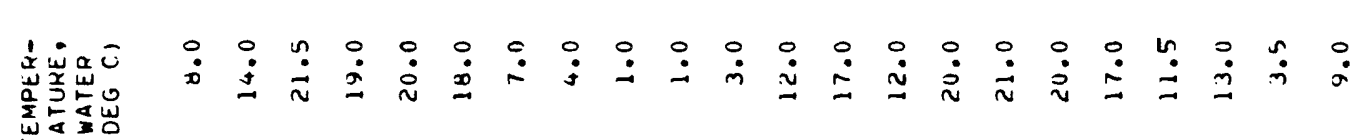

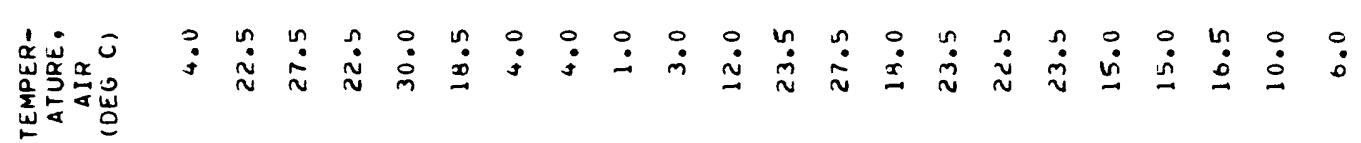

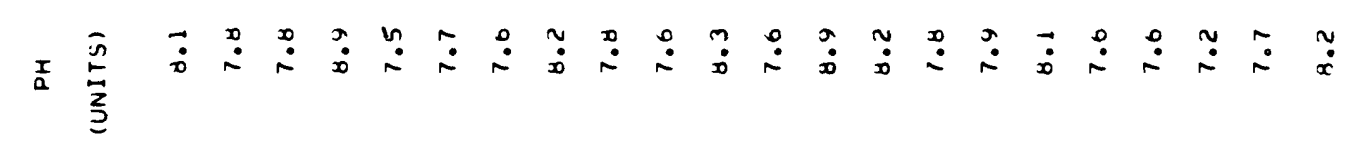

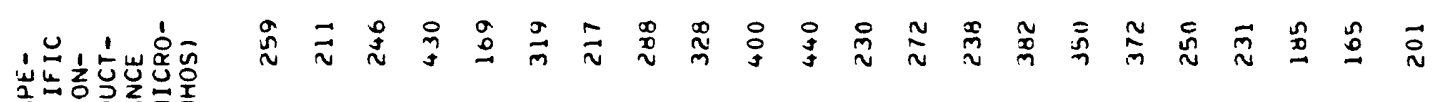

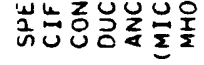

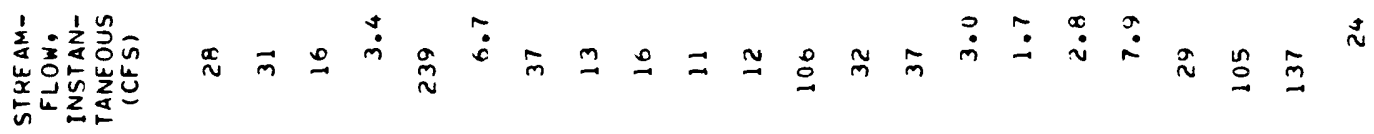

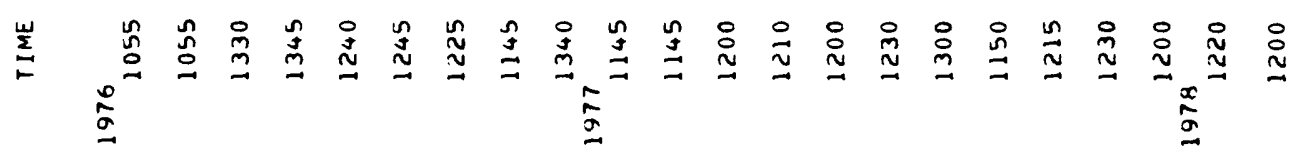

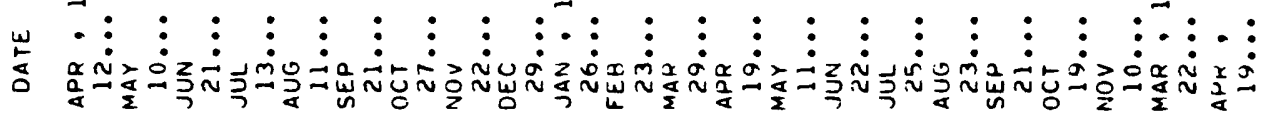




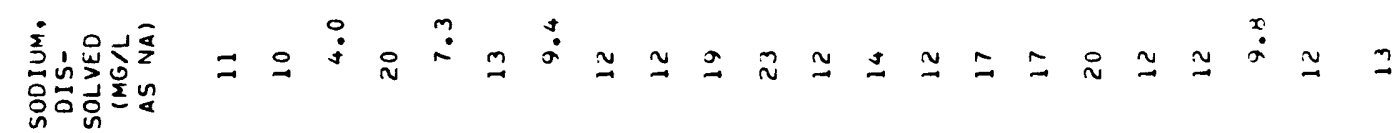

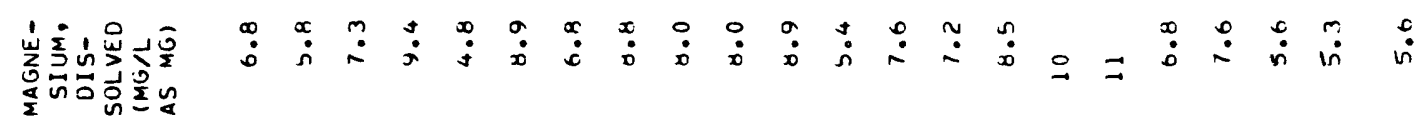

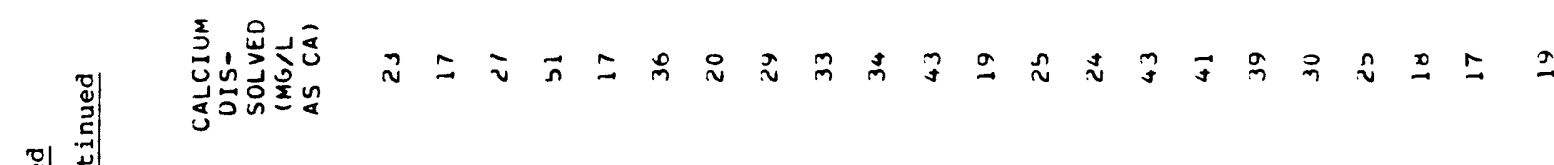

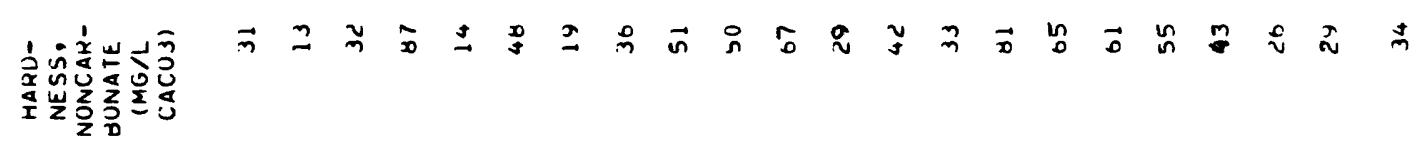

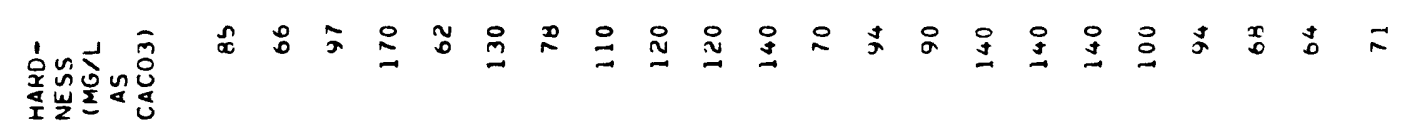

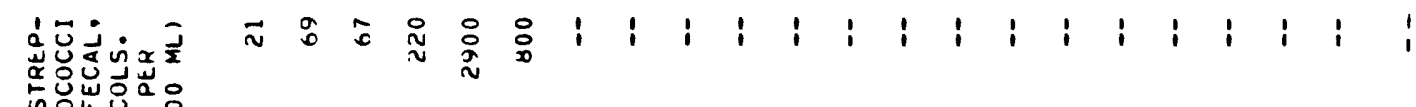

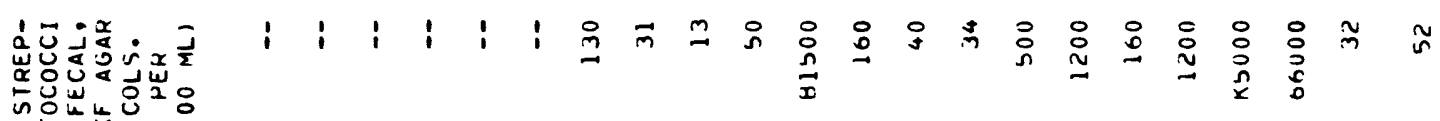

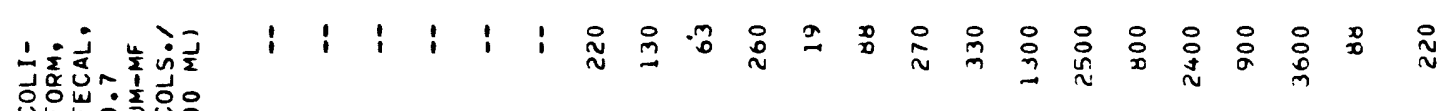

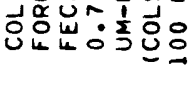

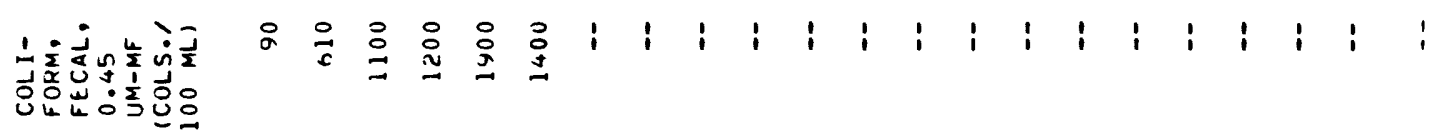

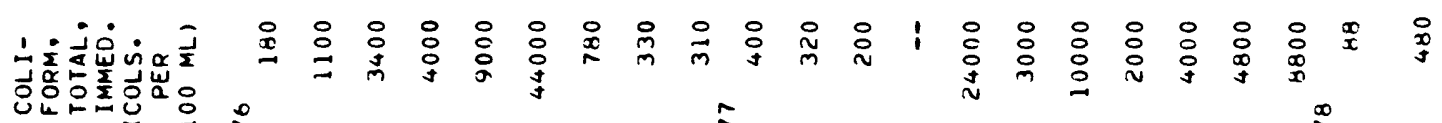

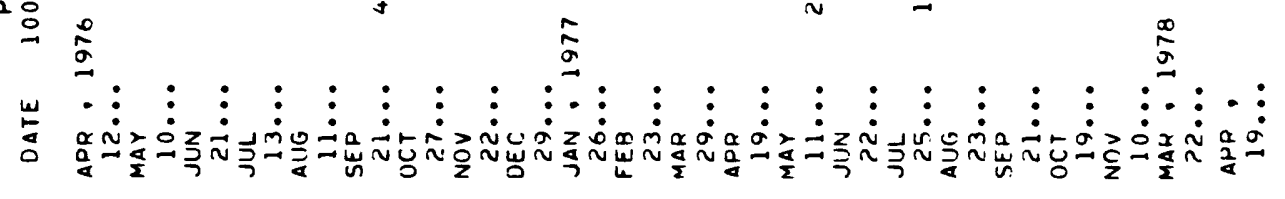




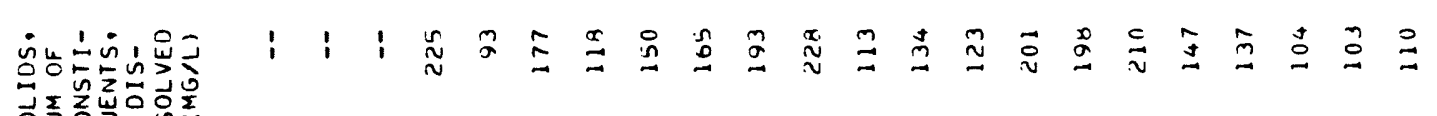

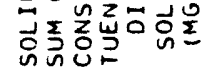

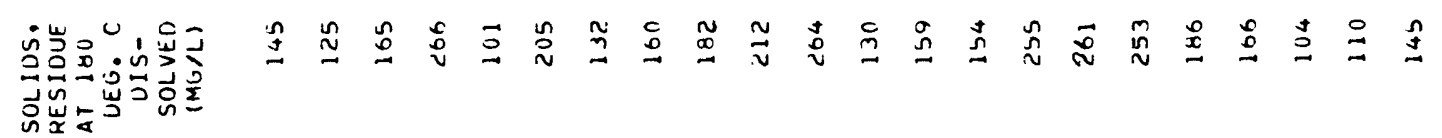

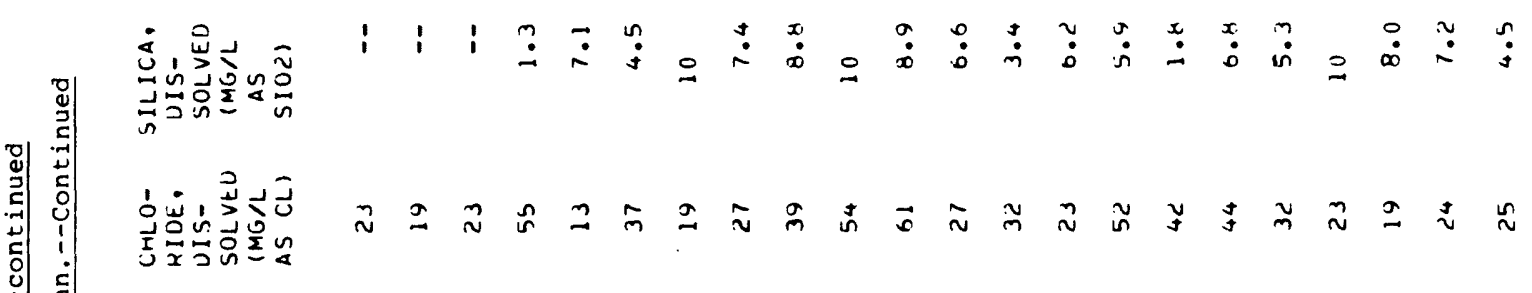

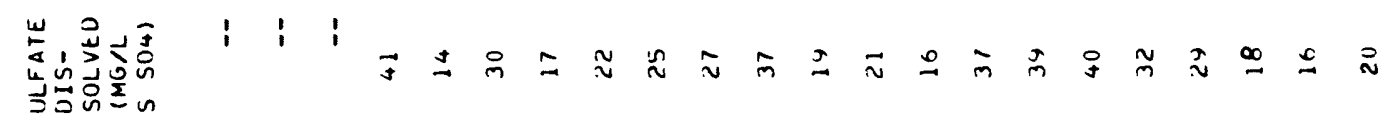

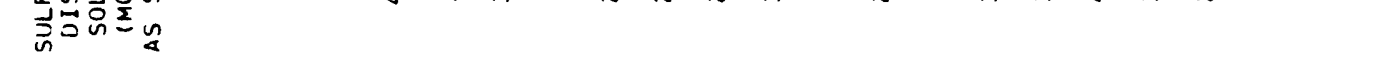

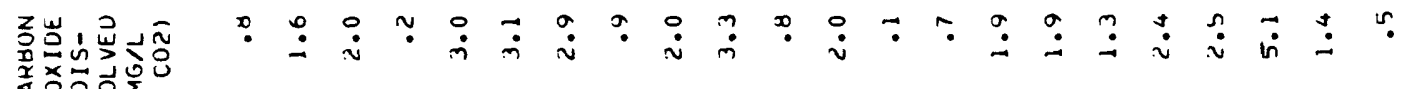

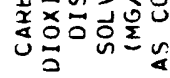

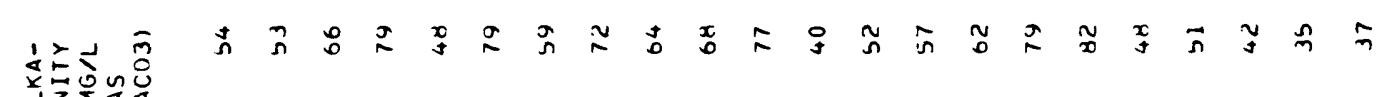

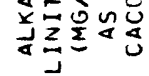

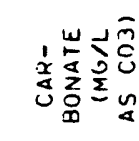

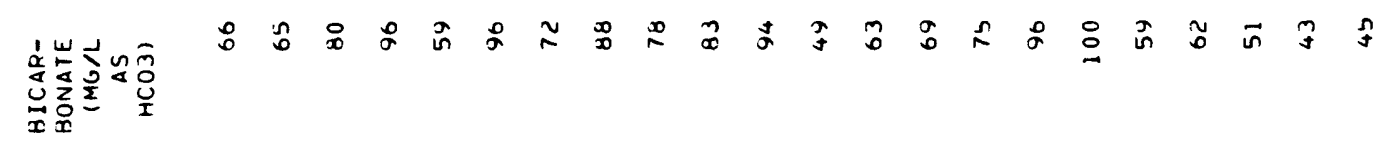

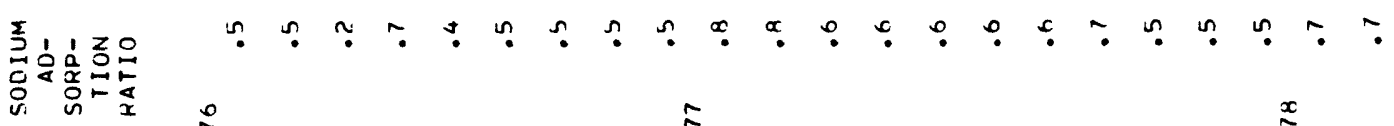

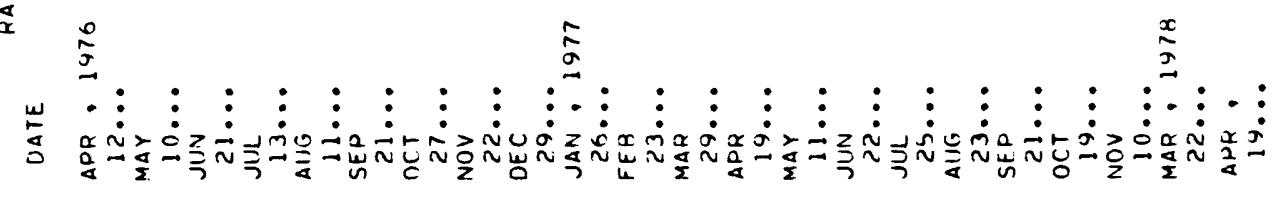




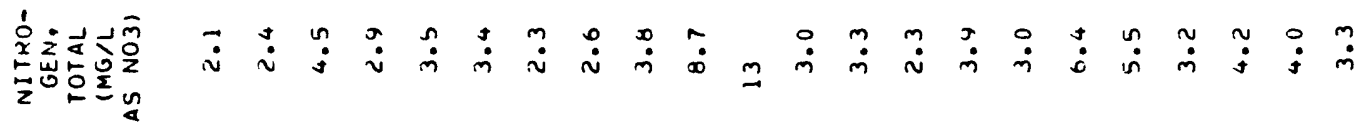

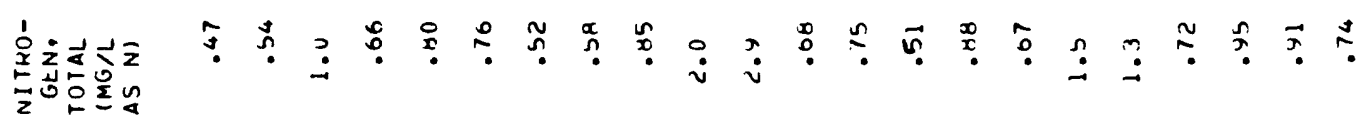

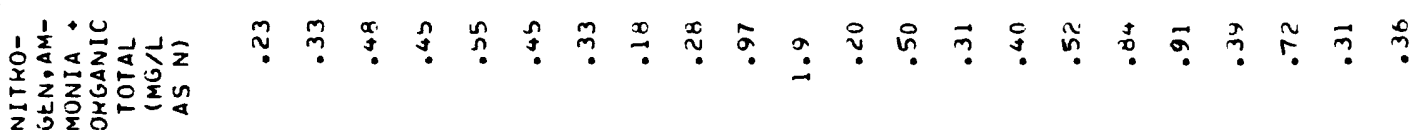

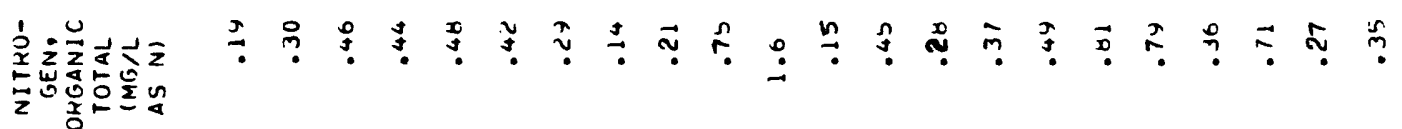

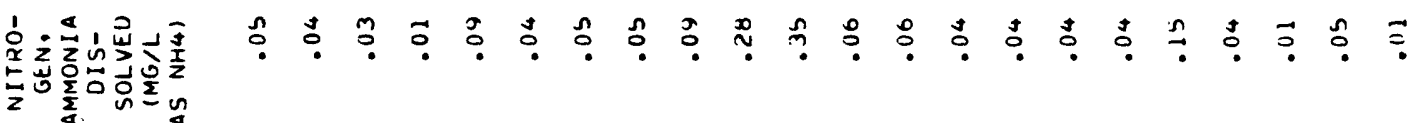

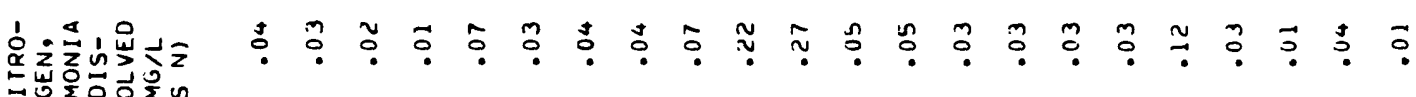

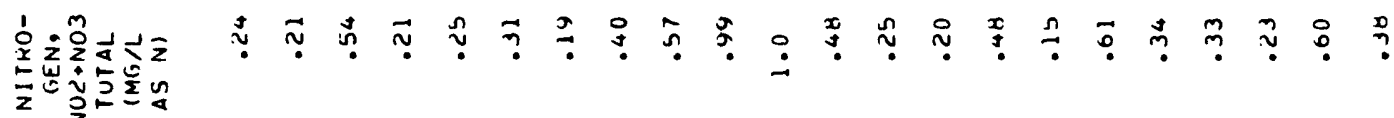

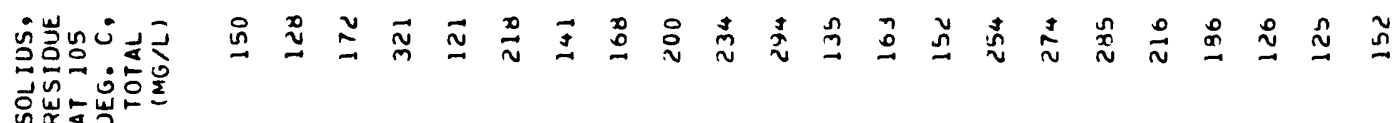

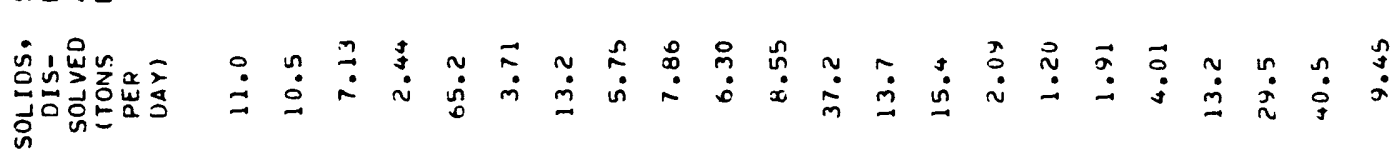

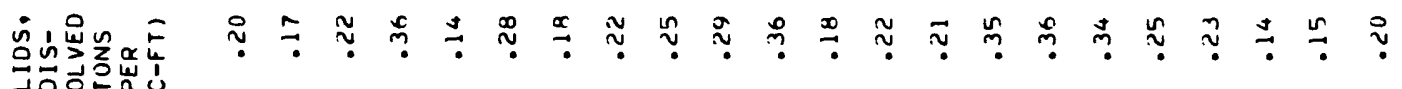

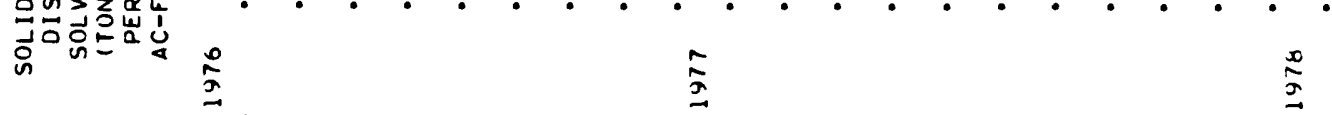

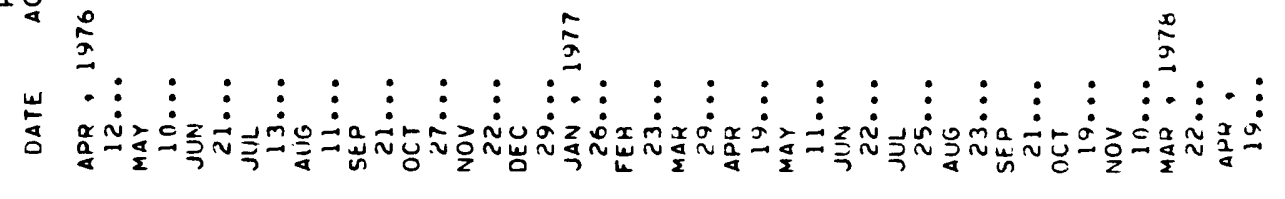


Table 11.--water-quality analyses.--continued

Site 3, Norwalk River at Cannondale, Conn.--Continuea -

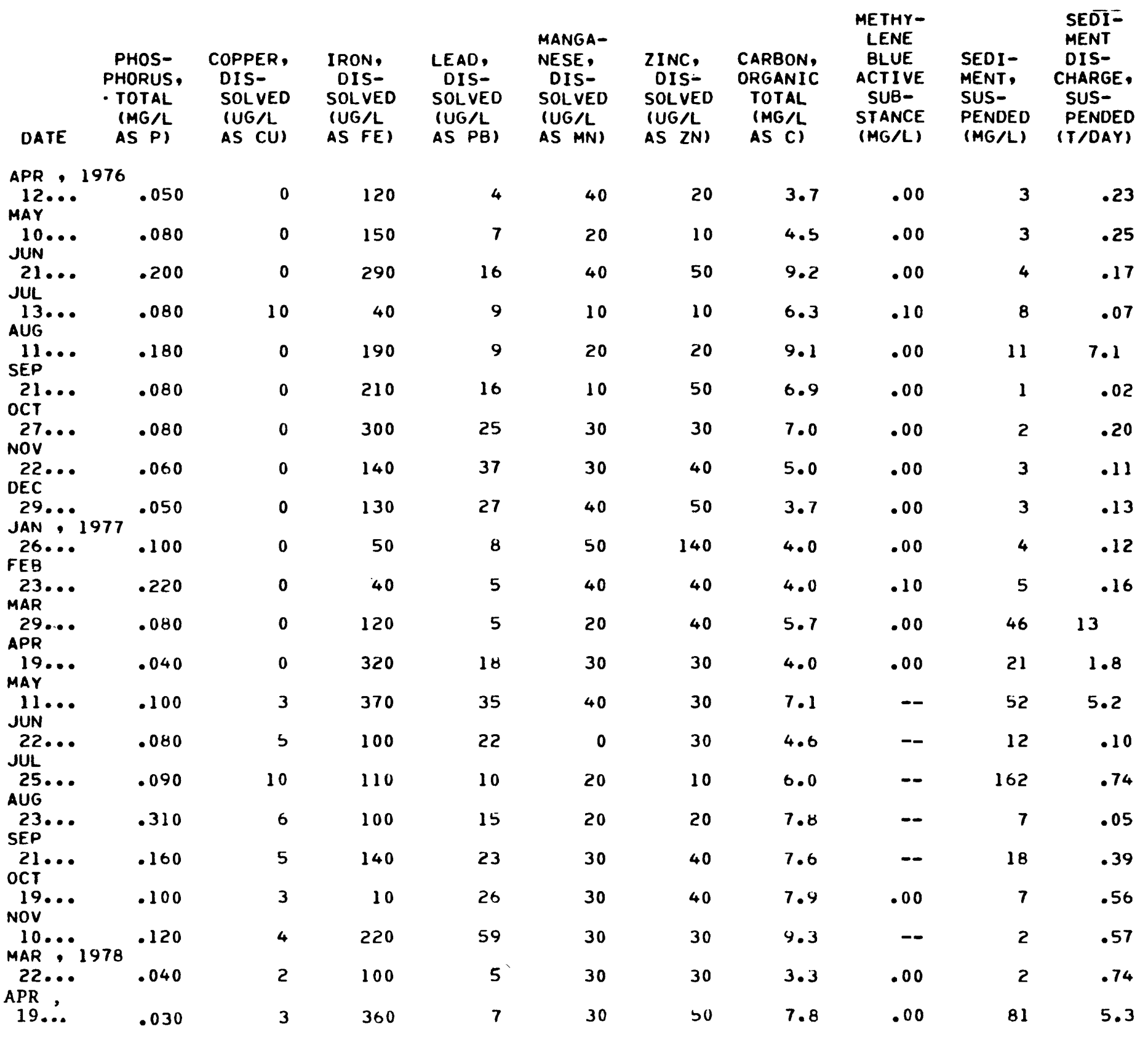




\section{NOTCE: This material may be protected copyright law (Mitle 17 U.S. Cade)}

Table 11.--water-quality analyses.--continued

Site 4, Comstock Brook at North Wilton, Conn.

TIME TANEOUS (MICRO-
DATE

$\begin{array}{ccc}\text { OXYGEN, } & \text { COLI- } & \text { COLI- } \\ \text { DIS- } & \text { FORM, } & \text { FORM, } \\ \text { SOLVED } & \text { TOTAL, } & \text { FECAL, } \\ \text { (PER- } & \text { IMMED. } & 0.45 \\ \text { CENT } & \text { (COLS. } & \text { UM-MF } \\ \text { SATUR- } & \text { PER } & \text { (COLS./ } \\ \text { ATION) } & 100 \mathrm{ML}) & \text { I00 ML) }\end{array}$

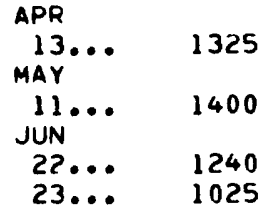

$\begin{array}{rrrrr}8.0 & 124 & 7.5 & 17.0 & 10.5 \\ 6.3 & 108 & 7.5 & 19.5 & 15.0 \\ 1.9 & 124 & 7.4 & 29.5 & 21.0 \\ \ldots & -. & -. & -. & \ldots\end{array}$

$\begin{array}{rr}1 & 11.4 \\ 1 & 10.5 \\ 1 & 8.4 \\ -. & -\end{array}$

.102

20

103

230

$93 \quad 330$

--

COLS./

STREP-

TOCOCCI

FECAL,

ICOLS.

$$
\text { PER }
$$

DATE $100 \mathrm{ML}$ )

APR

$13 \ldots$

MAY

$11 \ldots$

JUN

22 ...

$23 \ldots$

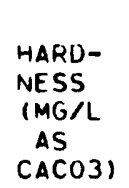

HARD-

NESS,

NONCAR -

BONATE

(MG/L

CACO3I

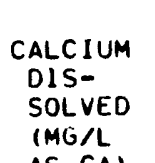

MAGNE-

SIUM, SODIUM.

DIS- DIS-

SOLVED SOLVED

(MG/L $\quad(M G / L$

AS MGI AS NA)

AS (A)
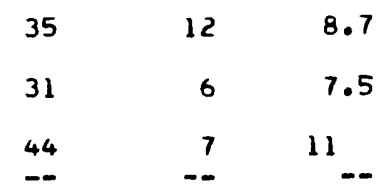

3.2

$6 . ?$

2.9

5.6

3.9

๖. 5

SOUIUM

AD- $\quad$ ICAR

SORP-

TION

BICAR -

IMG/L

AS

HCO3)

CAR-

BONATE

(MG/L

AS $\mathrm{CO} 3$

ALKA

IMG/

AS

CACIO)

CARBON

DIOXIDE

DIS-

SOLVEO

(MG/L

AS $(02)$

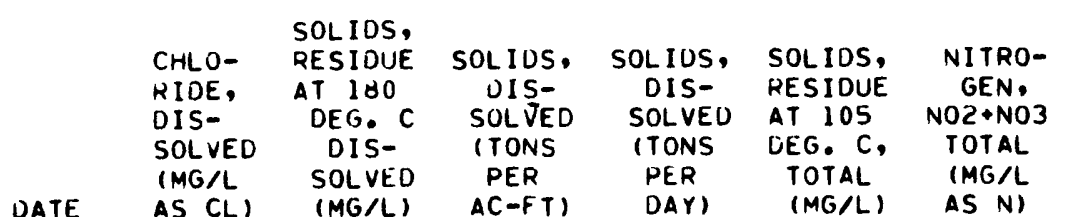

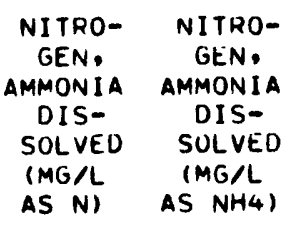

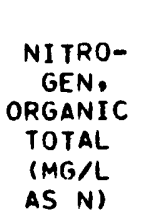

NITRO-

GEN, AMMONIA ORGANIC TOTAL IMG/L AS N)

NITROGEN, TOTAL (MG/L AS N)

APR 13.0

MAY

JUN

22 ...

$$
12
$$

62

$.08 \quad 1.34$

$81 \quad .12$

.01

.01

.19

.20

.32

8.9

$.09 \quad 1.17$

69

.02

.03

.33

.35

.44

9.7

.12

.45

$88 \quad .29$

.02

.03

. 38

.40

.69

$23 . .$.

\begin{tabular}{|c|c|c|c|c|}
\hline $\begin{array}{l}\text { ZINC, } \\
\text { DIS- } \\
\text { SOLVEO } \\
\text { (UG/L } \\
\text { AS ZN) }\end{array}$ & $\begin{array}{l}\text { CARBON, } \\
\text { ORGANIC } \\
\text { TOTAL } \\
\text { (MG/L } \\
\text { AS C) }\end{array}$ & $\begin{array}{l}\text { METHY- } \\
\text { LENE } \\
\text { BLUE } \\
\text { ACTIVE } \\
\text { SUB- } \\
\text { STANCE } \\
\text { (MG/L) }\end{array}$ & $\begin{array}{l}\text { SEDI - } \\
\text { MENT. } \\
\text { SUS- } \\
\text { PENDED } \\
\text { (MG/L) }\end{array}$ & $\begin{array}{l}\text { SEDI - } \\
\text { MENT } \\
\text { DIS- } \\
\text { CHARGE, } \\
\text { SUS- } \\
\text { PENDED } \\
\text { (T/DAY) }\end{array}$ \\
\hline 0 & 3.9 & .00 & 5 & .11 \\
\hline 0 & 1.9 & .00 & 2 & .03 \\
\hline 0 & 11 & .00 & 43 & .22 \\
\hline$-\infty$ & -- & - & $\cdots$ & \\
\hline
\end{tabular}

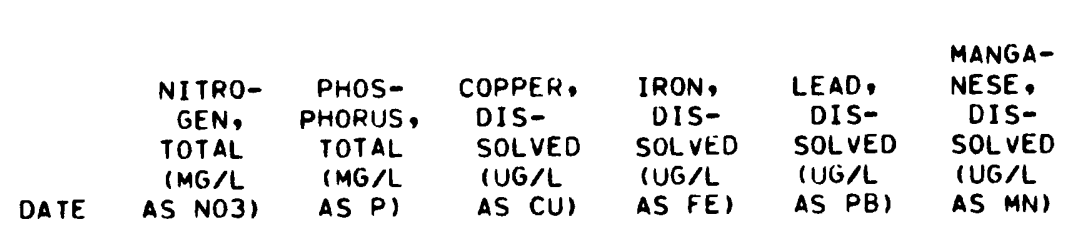

$\triangle P R$

MAY

MAY $11 \ldots$

$1.4 \quad .020$

0

70

720

100

JUN

$1.9 \quad .030$

0

9

430

10

$23 \ldots$

$3.1 \quad .050$

0
--

$-$ 


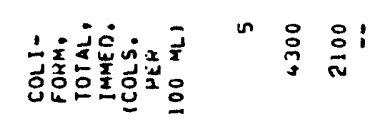

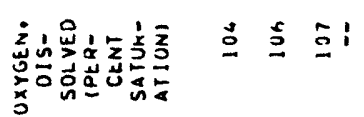

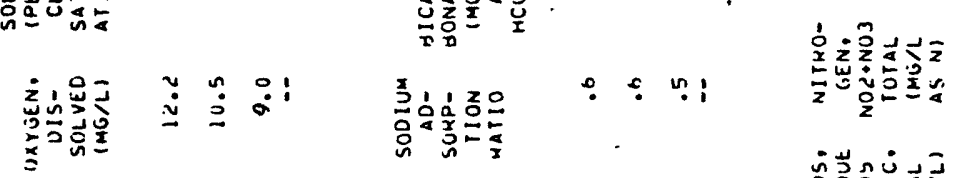

硋琣

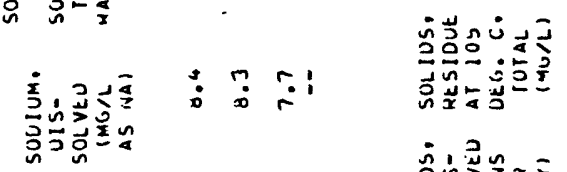

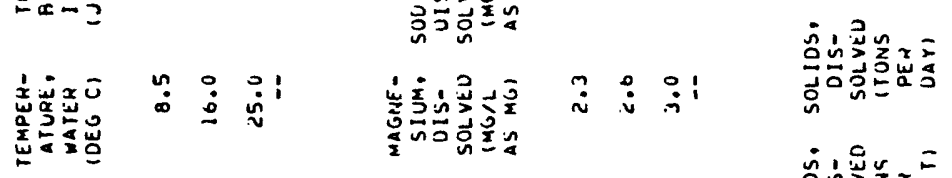

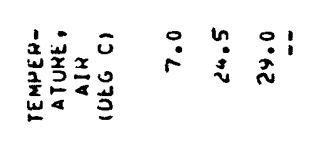

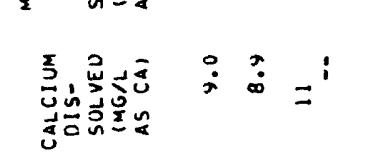

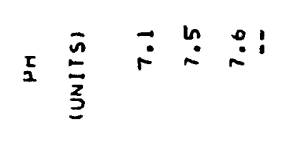

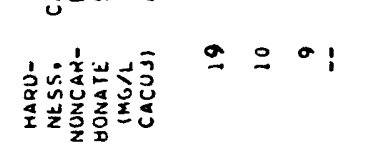

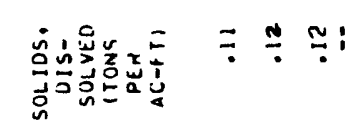

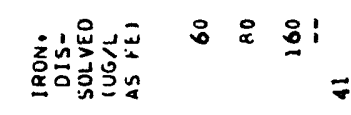

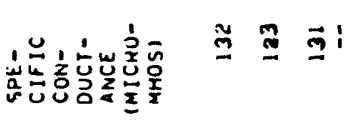

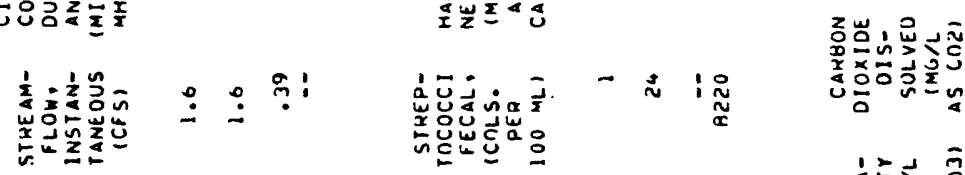

กำ

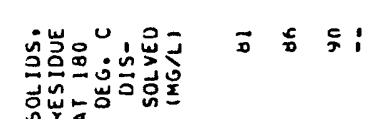

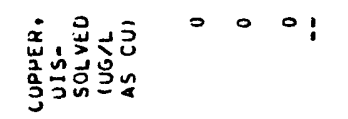

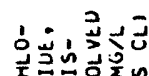

$\therefore \simeq$

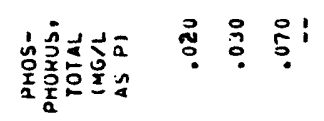

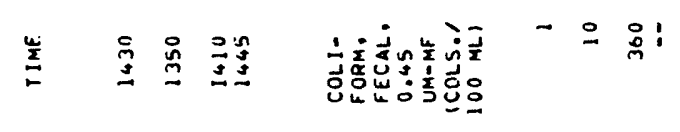

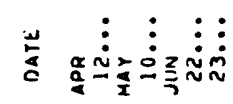

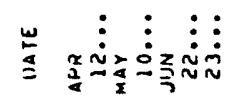

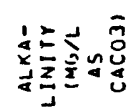

$\stackrel{2}{i}: \stackrel{p}{=}$

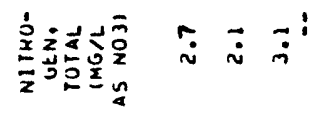

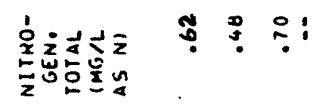

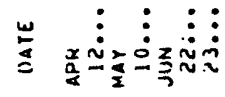

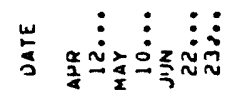




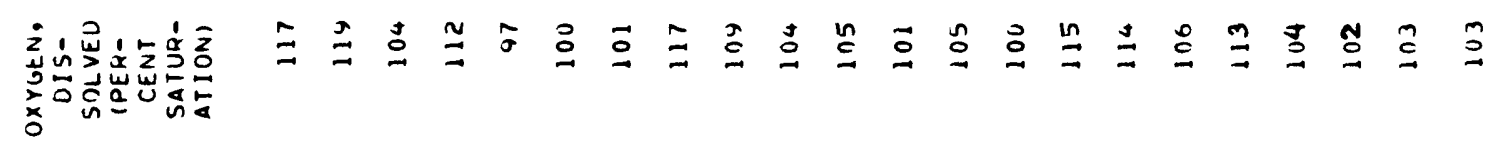

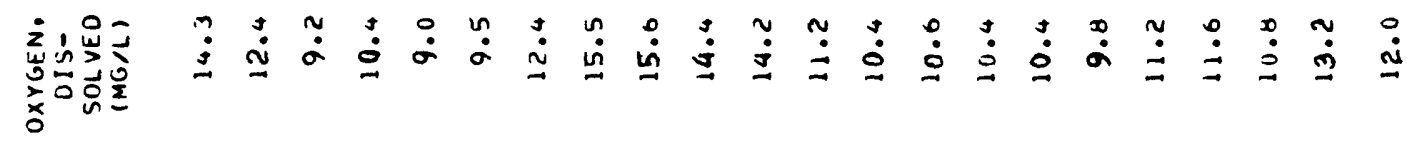

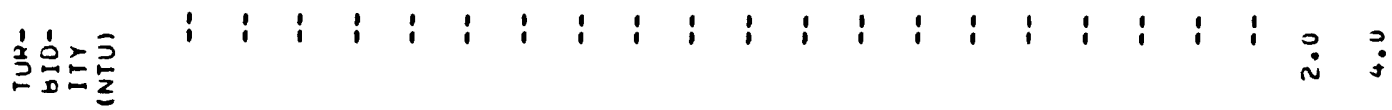

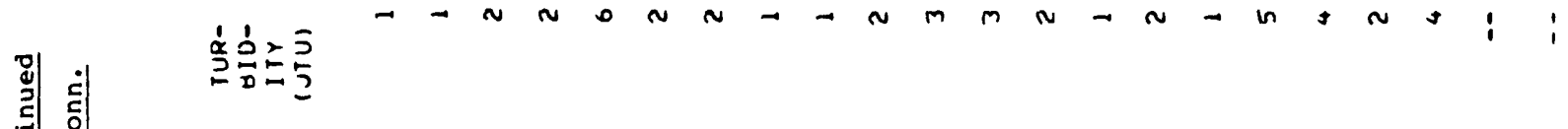

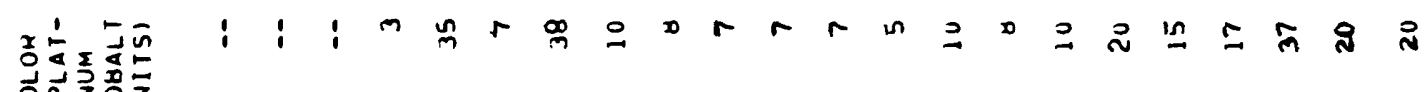

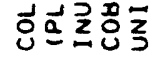

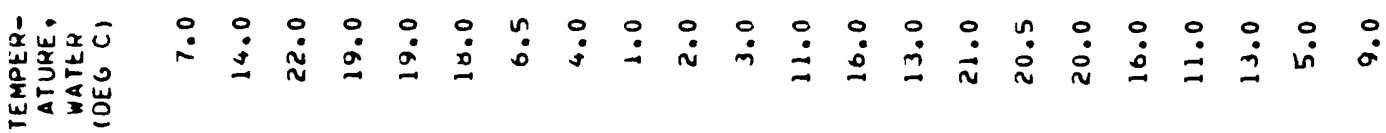

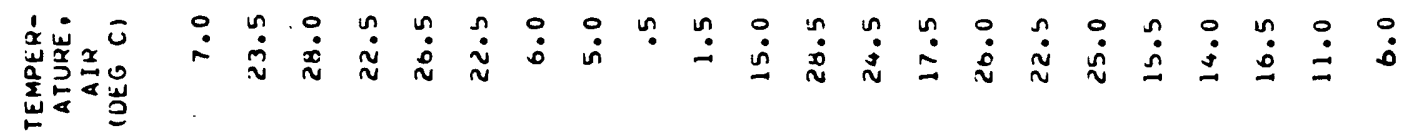

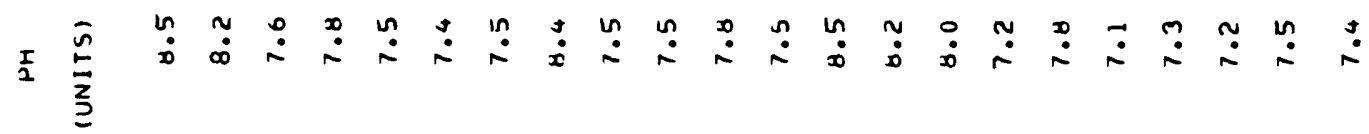

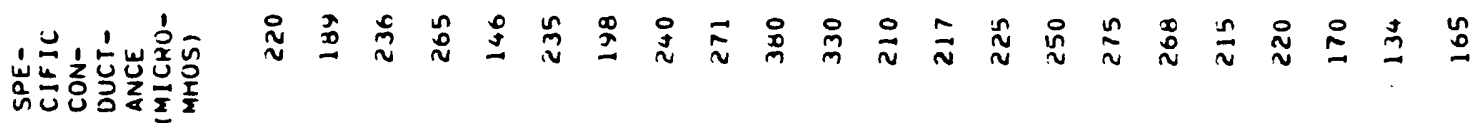

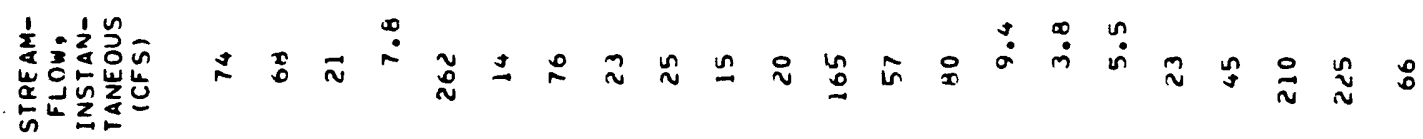

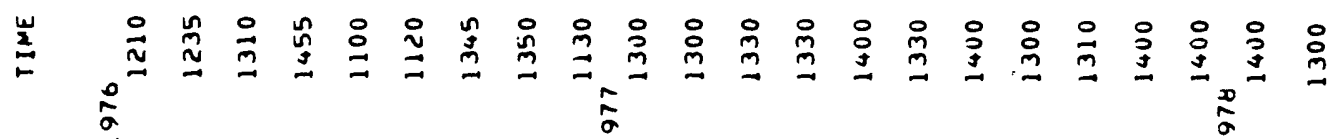

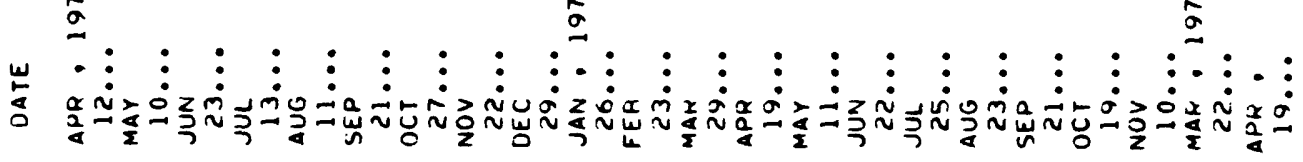




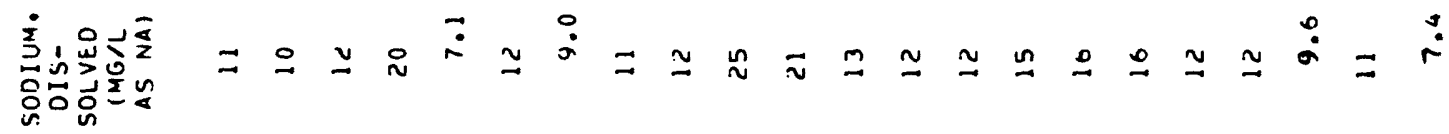

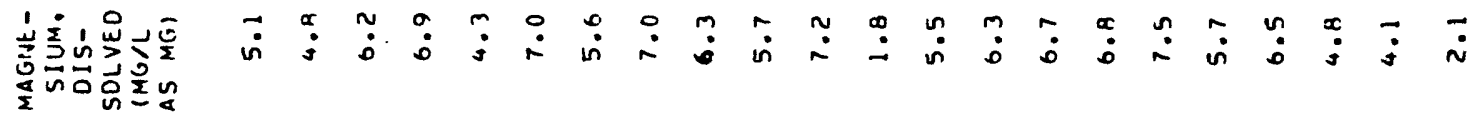

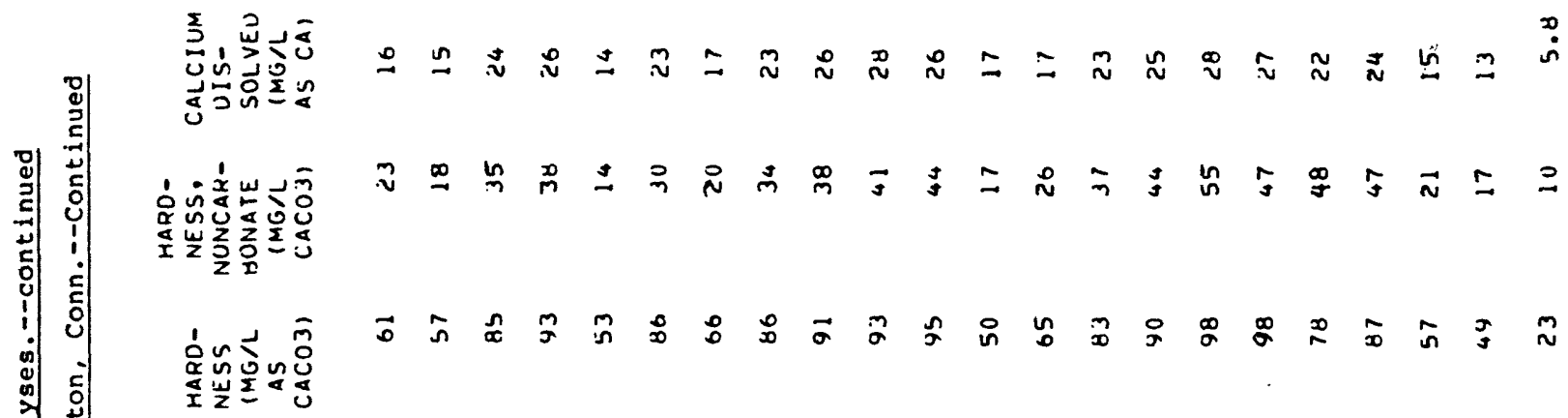

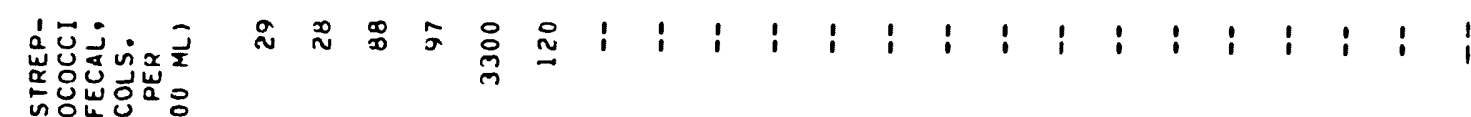
is

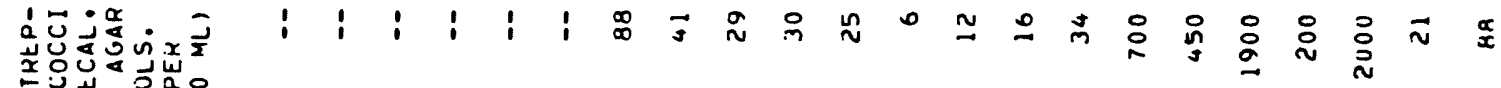

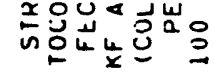

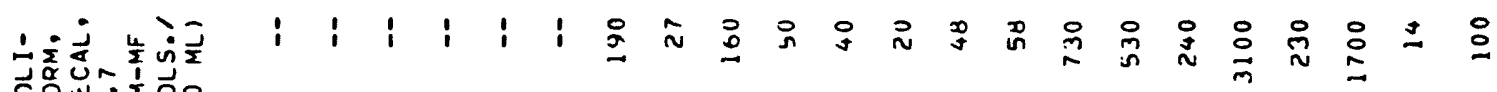

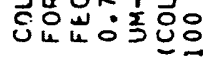

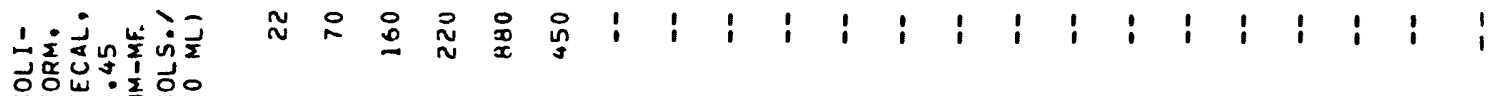

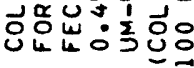

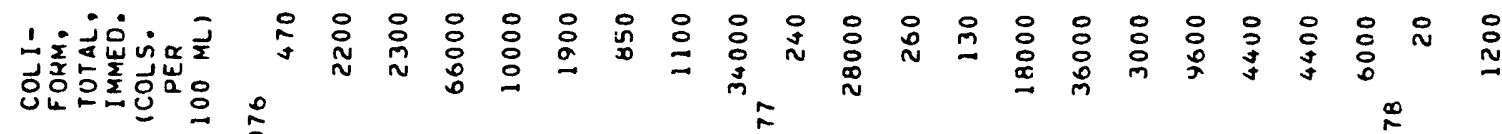

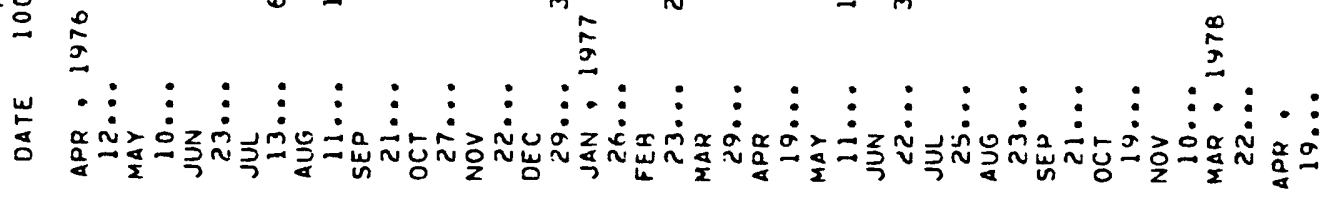




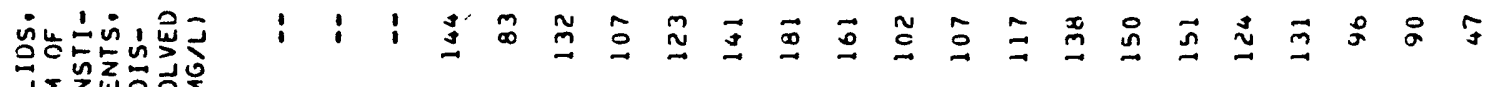

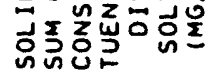

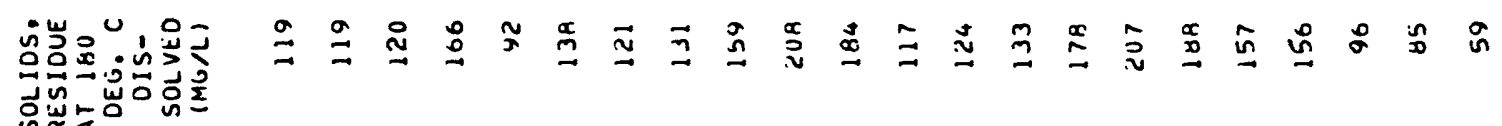

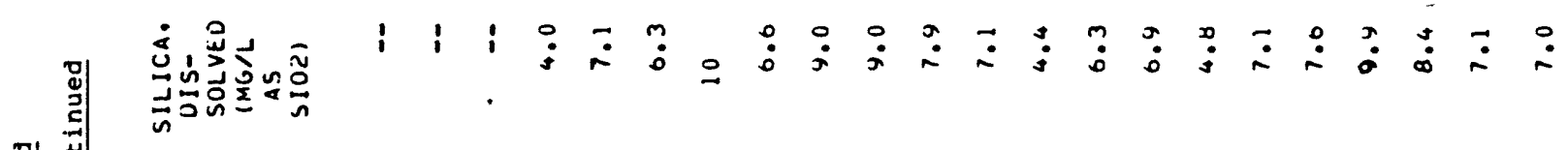

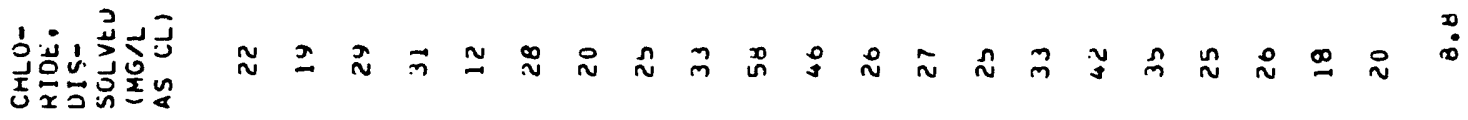

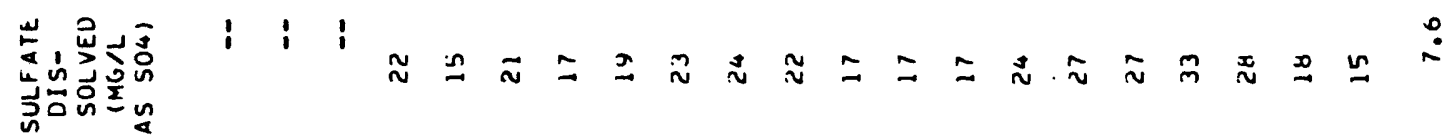

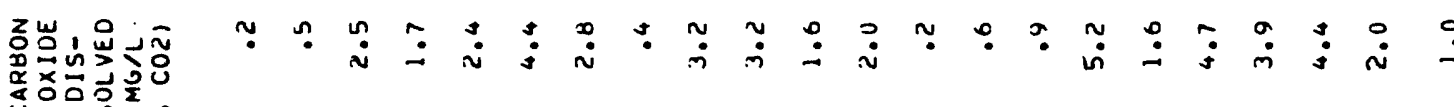

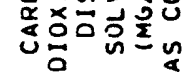

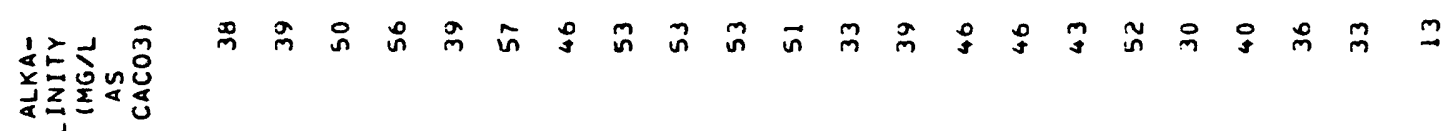

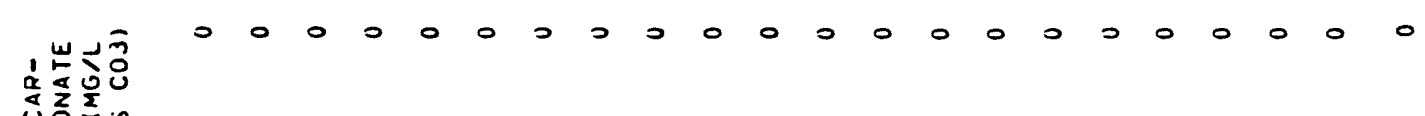

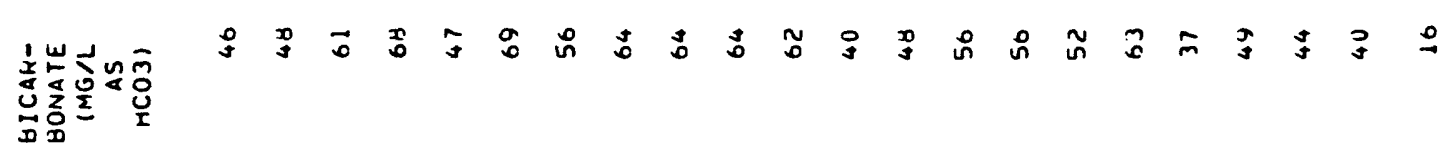

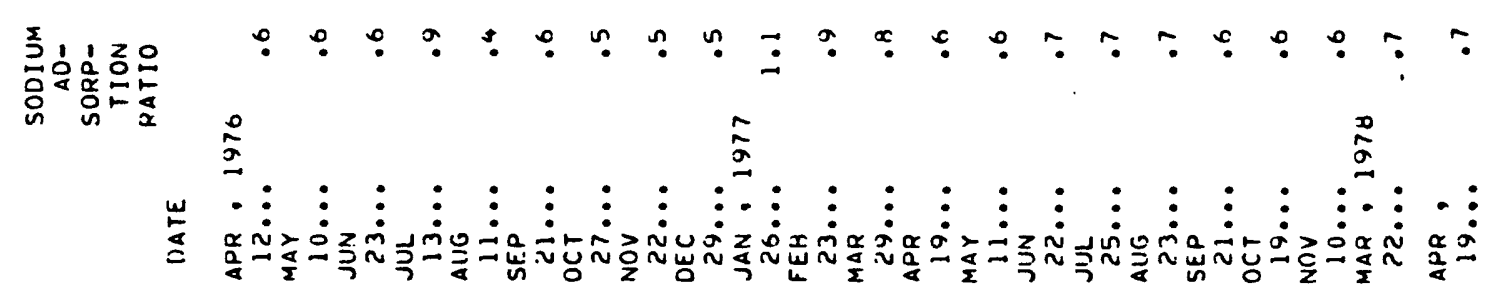




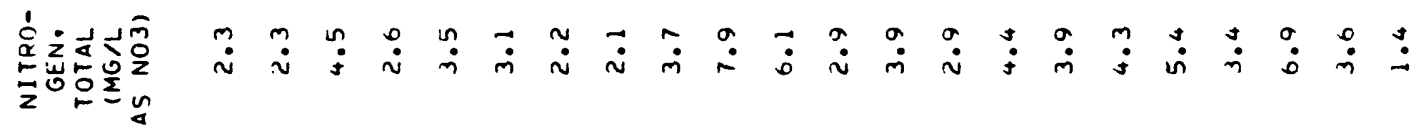

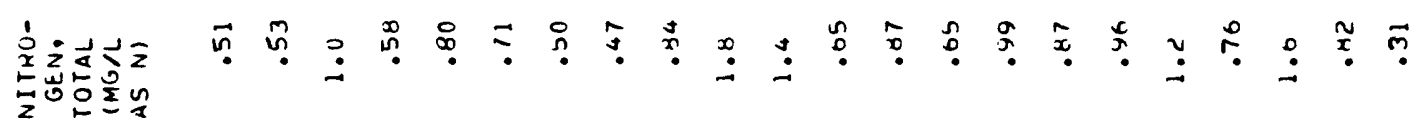

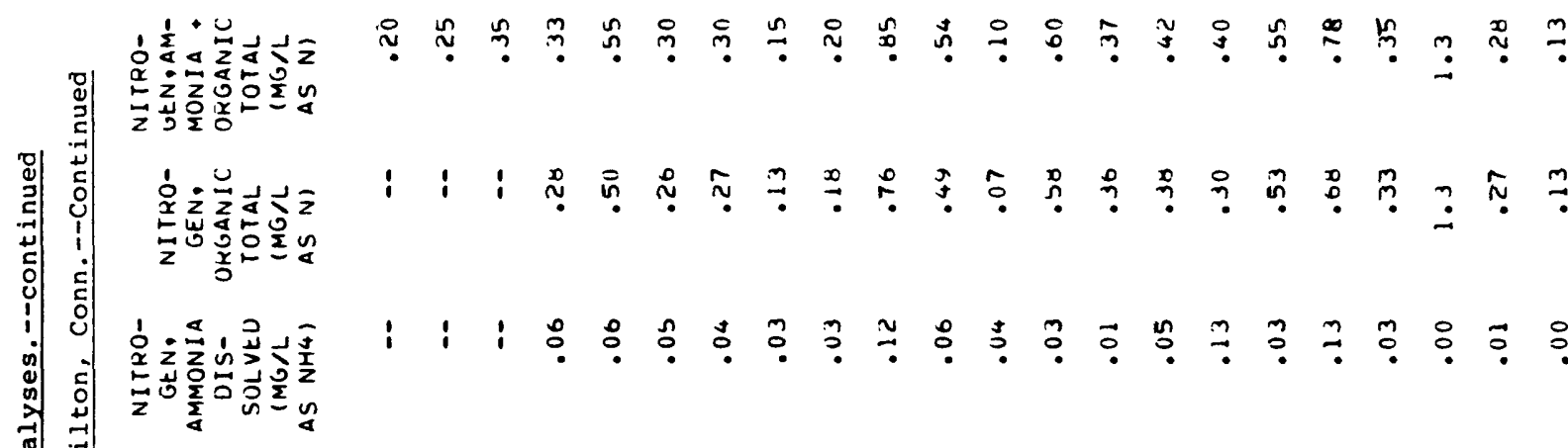

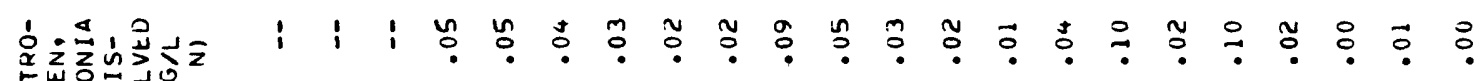

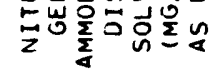

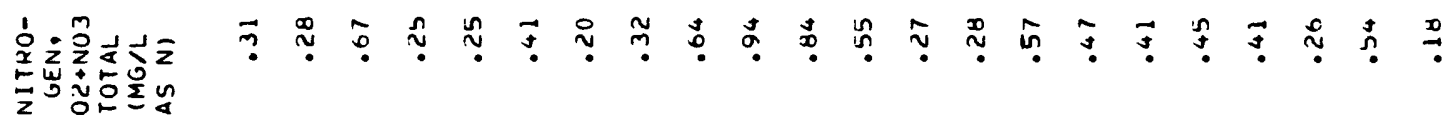

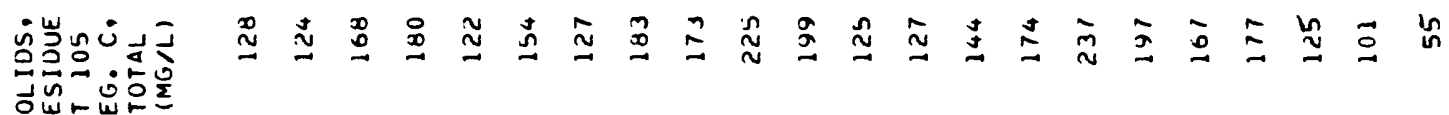

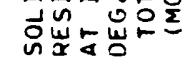

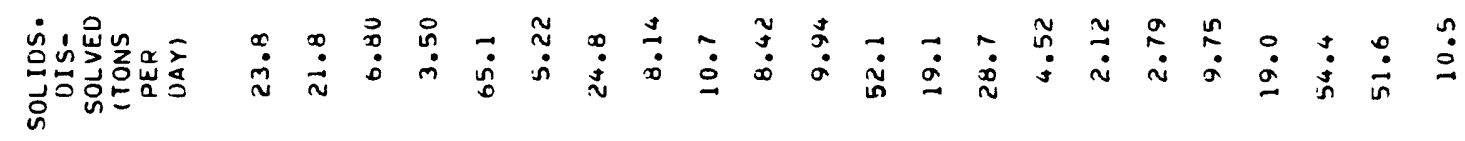

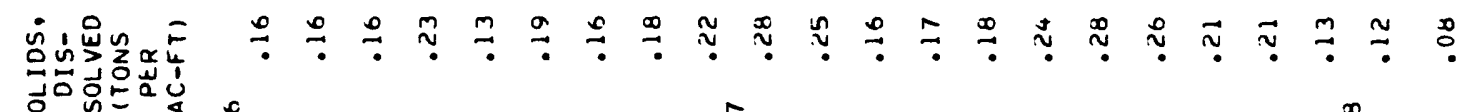

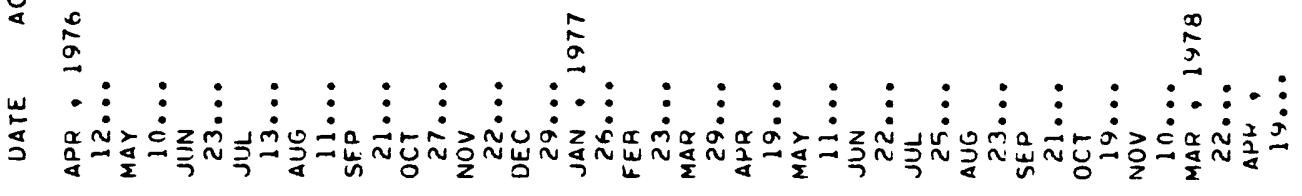




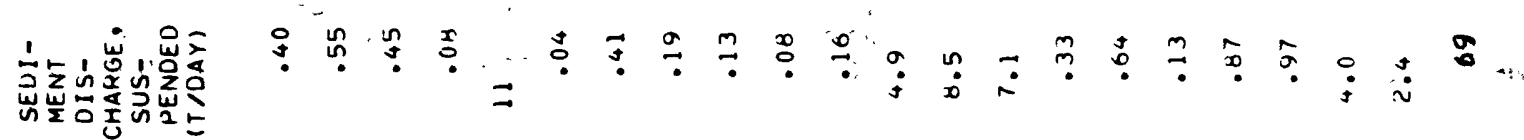

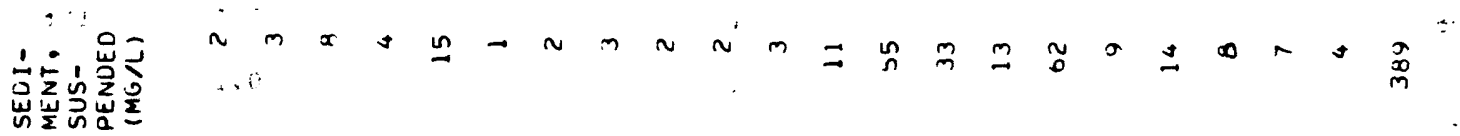

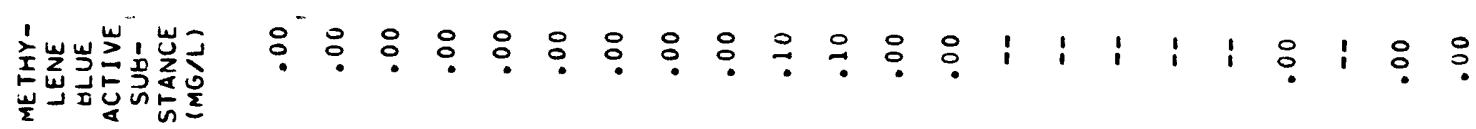

绨

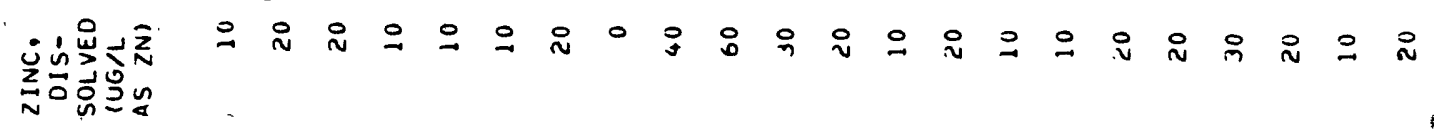

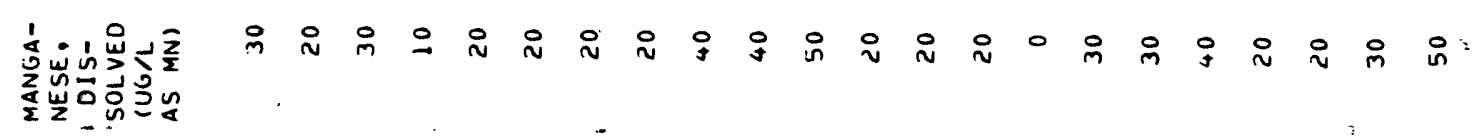

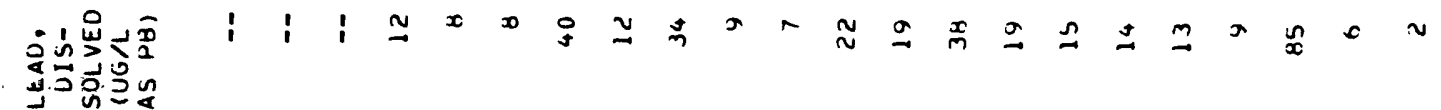

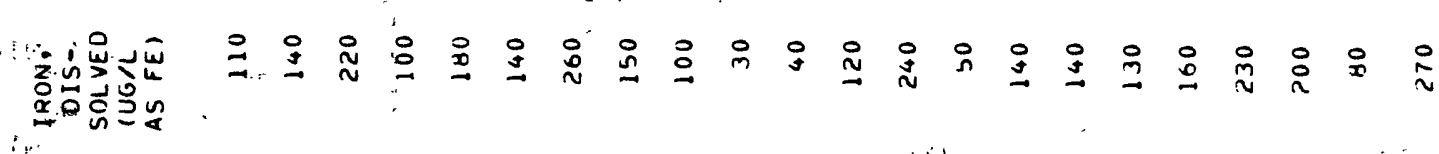

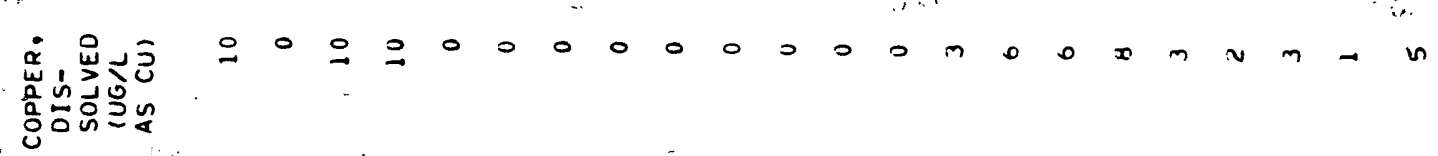

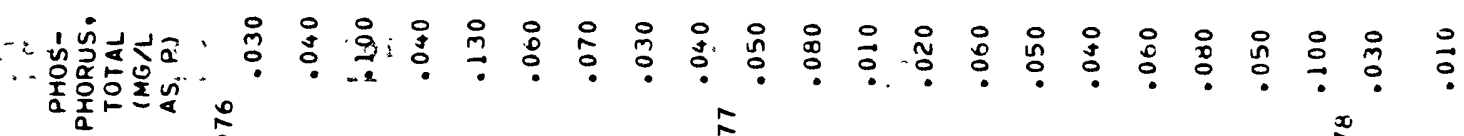

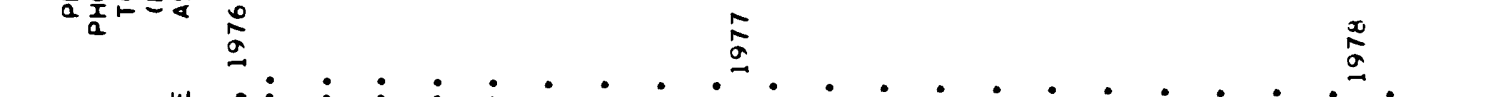

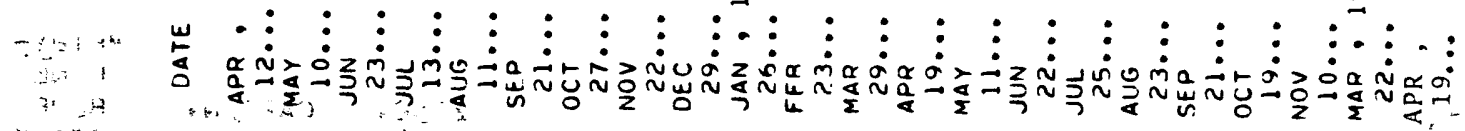

$\because 4: 2$

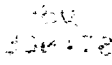


Table 11.--Water-quality analyses.--continued

Site 7, East Branch Silvermine River near Ridgefield, Conn.

APR

AP

APR $13 \cdots \quad 1005$

SPE-
CIFIC

STREAM- CON-

FLOW, DUCT-

TIME TANEOUS (MICRO-

(CFS) MHOS)

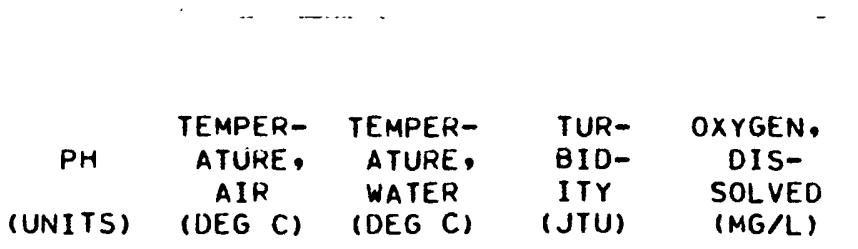

OXYGEN,

OIS-

SOLVED TOTAL,

IPER- IMMED.

CENT ICOLS.

SATUR- PEK

AT (ON) $100 \mathrm{ML}$ )

$11 \ldots 1010$

2.0
2.3
1.0
--

239

$7.7 \quad 13.0$

6.0

$1 \quad 13.3$

106

180

JUN

22... 1005

$23 \ldots 1005$

209

$\begin{array}{lll}7.5 & 21.0 & 13.5\end{array}$

110.2

$97 \quad 6500$

$\begin{array}{lll}7.4 & 24.5 & 18.0\end{array}$

$\begin{array}{rr}2 & 7.9 \\ -- & --\end{array}$

83

2100

COL I -

FORM, STREP-

FECAL, TOCOCCI

$\begin{array}{ccc} & \text { HARD- } \\ \text { HAFD- } & \text { NESS, } & \text { CALCIUM } \\ \text { NESS } & \text { NONCAR- } & \text { DIS- } \\ \text { (MGLL } & \text { BONATE } & \text { SOLVEU } \\ \text { AS } & (M G / L & (M G / L \\ \text { CACN3) } & \text { CACO3) } & \text { AS CA) }\end{array}$

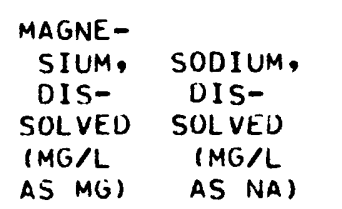

SODIUM

$A O-$

SORP-

TION

BICAR -

BONATE

0.45 FECAL,
UM-MF ICOLS.

(COLS.) PER

DATE

$100 \mathrm{ML})$

(ACO3) (ACO3)

AS CA)

AS M(G) AS NA)

RATIO

IMG/L

AS

$\mathrm{HCO} 3)$

CAK-

BONATE

(MG/L

AS $(03)$ APR

13 .

MAY

11 ..

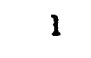

$\begin{array}{lll}74 & 20 & 18 \\ 73 & 13 & 18 \\ 95 & 16 & 23 \\ -- & -- & \end{array}$

$\begin{array}{rl}7.1 & 10 \\ 6.7 & 10 \\ 9.0 & 11 \\ -- & -\end{array}$

.5

.5

66

0

22...

$23 \ldots$

200

B1 40

--

-

--

.5

72

0

0

APR

\begin{tabular}{|c|}
\hline $\begin{array}{l}13 \cdots \\
\text { MAY }\end{array}$ \\
\hline $\operatorname{JUN}^{11 \ldots}$ \\
\hline
\end{tabular}

ALKA-

LINITY

(MS) $/ L$

$A S$
CACO3) $(M G / L$

CHLO-
RIDE,
UIS-
SOLVED
(MGIL
AS CLI

SOLIOS.

AT 1 HO

DEG. C

DIS-

SOLVEO

(MG/L) $\begin{array}{cc}\text { SOLIDS, } & \text { SOLIDS, } \\ \text { DIS- } & \text { DIS- } \\ \text { SOLVED } & \text { SOLVEU } \\ \text { (TONS } & \text { ITONS } \\ \text { PER } & \text { PER }\end{array}$

$A C-F T$ I

DAY)
SOLIDS.

KESIDUE

AT IOS

OEG. C,

TUTAL

(MG/L)
NITROGEN, $\mathrm{NO} 2+\mathrm{NO}_{3}$ TOTAL

(MG/L
$A S N)$
NITR()-

GEN, AMMONIA + OKGANIC TOTAL (MG/L AS N)

$\begin{array}{lll}54 & 2.1 & 14 \\ 59 & 3.6 & 17 \\ 79 & 6.1 & 19 \\ - & -\ldots & \end{array}$

$\begin{array}{rrr}128 & .17 & .09 \\ 124 & .17 & .77 \\ 108 & .15 & .29 \\ .- & .0 & .0\end{array}$

141
122

.60

.23

.38

.35

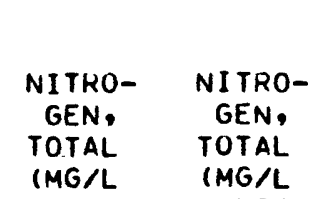

$\begin{array}{lll} & & \\ \text { PHOS- } & \text { COPPER, } & \text { IRON, } \\ \text { PHORUS, } & \text { OIS- } & \text { UIS- } \\ \text { TOTAL } & \text { SOLVED } & \text { SOLVED } \\ \text { (MG } & \text { (UG/L } & (U G / L \\ \text { AS P) } & \text { AS CU) } & \text { AS FE) }\end{array}$
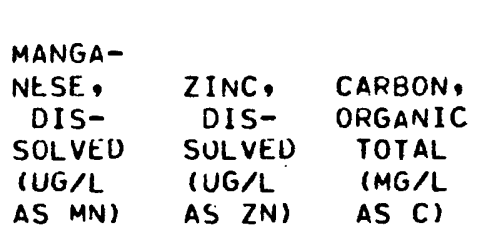

METHY -

LENE

BLUE

ACTIVE

SUS-

STANCE

(MG/L)

\section{APR}

13 .

$3.7 \quad .020$

10

170

100

0

$2.1 \quad .00$

$11 \ldots .78$

$3.5 \quad .030$

0

200

120

3.6

.00

22 ...

.83

$\begin{array}{rr}3.7 & .050 \\ - & -\end{array}$

0

250

140

10

8.3

.00 
Table 11.--Water-quality analyses.--continued

Site 8, East Branch Silvermine River near North wilton, Conn.

i

\begin{tabular}{|c|c|c|c|c|c|c|c|c|c|c|}
\hline & TIME & $\begin{array}{l}\text { STREAM- } \\
\text { FLOW, } \\
\text { INSTAN- } \\
\text { TANEOUS }\end{array}$ & $\begin{array}{l}\text { SPE- } \\
\text { CIFIC } \\
\text { CON- } \\
\text { DUCT- } \\
\text { ANCE } \\
\text { IMICRO- }\end{array}$ & PH & $\begin{array}{l}\text { TEMPER- } \\
\text { ATURE, } \\
\text { AIR }\end{array}$ & $\begin{array}{l}\text { TEMPER- } \\
\text { ATURE, } \\
\text { WATER }\end{array}$ & $\begin{array}{l}\text { TUR- } \\
\text { BIU- } \\
\text { ITY }\end{array}$ & $\begin{array}{c}\text { OXYGEN, } \\
\text { DIS- } \\
\text { SOLVED }\end{array}$ & $\begin{array}{c}\text { OXYGEN. } \\
\text { OIS- } \\
\text { SOLVED } \\
\text { IPER- } \\
\text { CENT } \\
\text { SATUR- }\end{array}$ & $\begin{array}{l}\text { COLI- } \\
\text { FORM, } \\
\text { TOTAL, } \\
\text { IMMED } \\
\text { ICOLS. } \\
\text { PER }\end{array}$ \\
\hline$A T$ & & (CF S) & MHOSI & (UNITS) & $(D E G \quad C)$ & $(D E G C)$ & (JTU) & $(M G / L)$ & ATI (ON) & $100 \mathrm{ML})$ \\
\hline
\end{tabular}

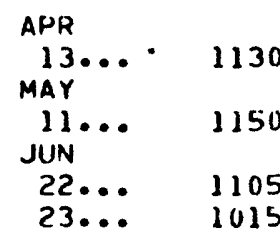

$\begin{array}{ll}6.2 & 185 \\ 4.9 & 165 \\ 4.2 & 175 \\ - & -\end{array}$

$\begin{array}{rrr}7.9 & 12.0 & 8.0 \\ 7.9 & 20.0 & 15.5 \\ 7.8 & 26.0 & 21.5 \\ -- & -- & --\end{array}$

$\begin{array}{rrrr}1 & 12.6 & 105 & 190 \\ 1 & 10.6 & 105 & 3400 \\ 1 & 8.8 & 99 & 200 \\ -- & -- & -- & -\end{array}$

\begin{tabular}{|c|c|c|c|c|c|c|c|c|c|c|}
\hline & $\begin{array}{l}\text { COLI- } \\
\text { FORM, } \\
\text { FECAL, } \\
0.45 \\
\text { UM-MF } \\
\text { ICOLS., }\end{array}$ & $\begin{array}{c}\text { STREP- } \\
\text { TOCOCCI } \\
\text { FECAL, } \\
\text { ICOLS. } \\
\text { PER }\end{array}$ & $\begin{array}{l}\text { HARD- } \\
\text { NESS } \\
\text { IME,/L } \\
\text { AS }\end{array}$ & $\begin{array}{l}\text { HARD- } \\
\text { NESS, } \\
\text { NONCAR- } \\
\text { BONATE } \\
\text { IMG/L }\end{array}$ & $\begin{array}{l}\text { CALCIUM } \\
\text { DIS- } \\
\text { SOLVED } \\
\text { (MG/L }\end{array}$ & $\begin{array}{l}\text { MAGNE- } \\
\text { SIUM, } \\
\text { DIS- } \\
\text { SOLVED } \\
\text { IMG/L }\end{array}$ & $\begin{array}{l}\text { SOOIUM, } \\
\text { UIS- } \\
\text { SULVED } \\
\text { IMG/L }\end{array}$ & $\begin{array}{l}\text { SOOIUM } \\
\text { AD- } \\
\text { SORP- } \\
\text { TION } \\
\text { RATIO }\end{array}$ & $\begin{array}{c}\text { BICAR- } \\
\text { BONATE } \\
\text { IMG/L } \\
\text { AS }\end{array}$ & $\begin{array}{l}\text { CAR- } \\
\text { BUNATE } \\
\text { (MG/L }\end{array}$ \\
\hline DATE & $100 \mathrm{ML})$ & $100 \mathrm{ML})$ & (ACO3) & $(A C O 3)$ & AS (A) & AS MG) & AS NA) & & $\mathrm{HCO3)}$ & AS $(03)$ \\
\hline
\end{tabular}

APR
$13 \ldots$
MAY
$11 \ldots$
JUN
$22 \ldots$
$23 \ldots$

$\begin{array}{rrr}4 & 1 & 50 \\ 9 & 23 & 53 \\ -0 & 100 & 70\end{array}$

$\begin{array}{ccc}50 & 17 & 14 \\ 53 & 9 & 13 \\ 70 & 14 & 18 \\ -- & - & \end{array}$

$\begin{array}{rrrrr}5.2 & 8.6 & .5 & 48 & 0 \\ 5.1 & 6.2 & .5 & 54 & 0 \\ 6.1 & 8.0 & .4 & 68 & 0 \\ -- & -- & -. & -1 & --\end{array}$

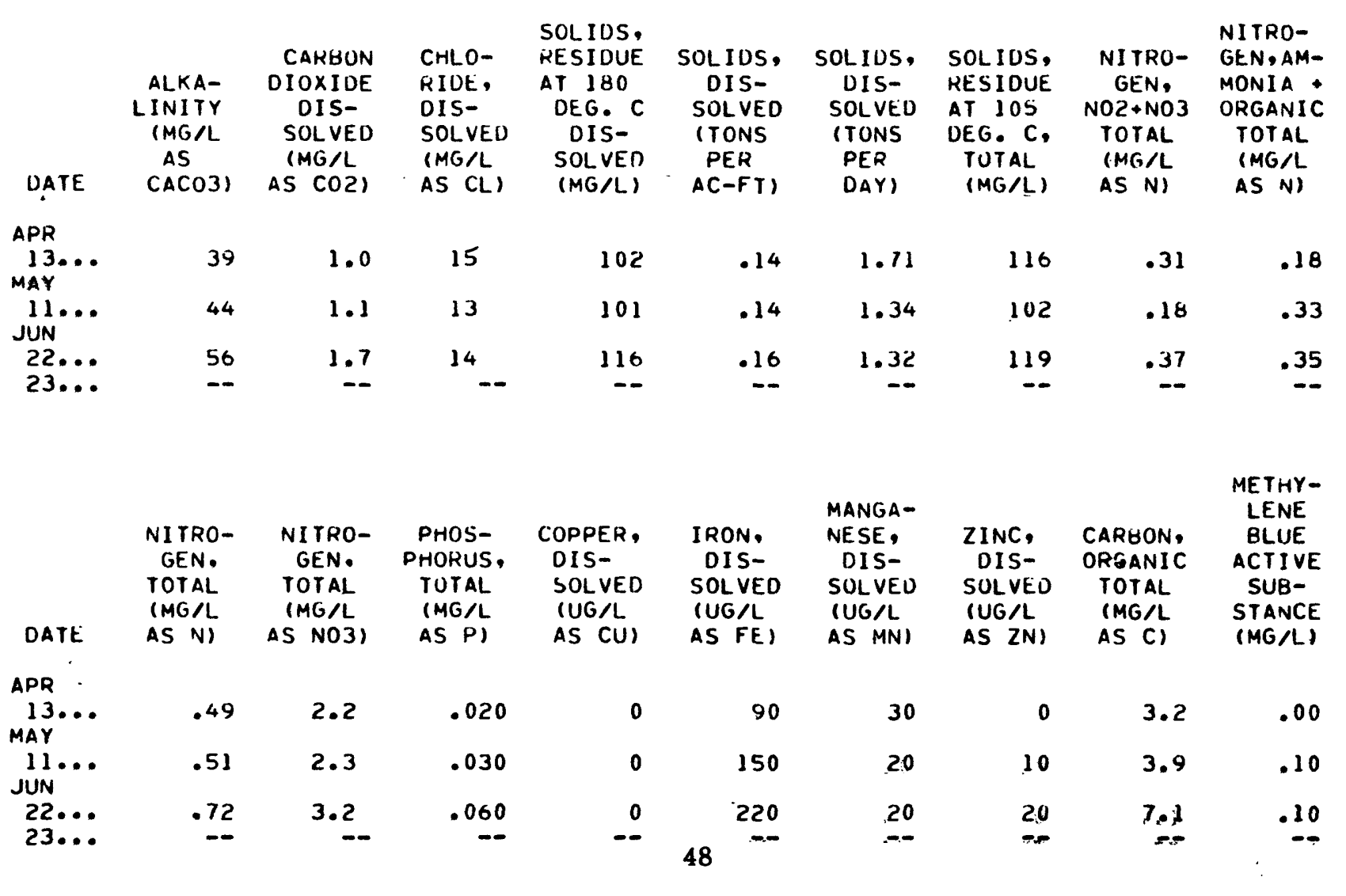




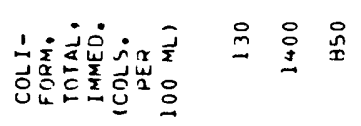

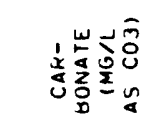

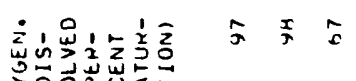

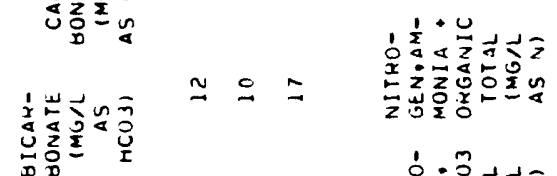

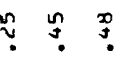

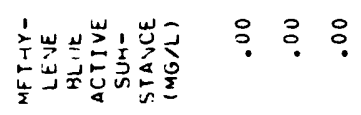

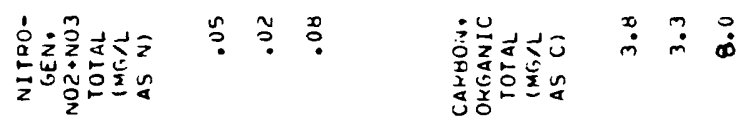

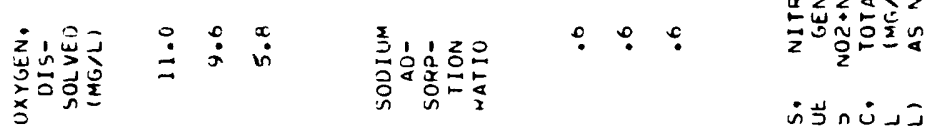

$: \approx:$

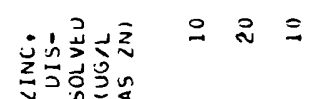

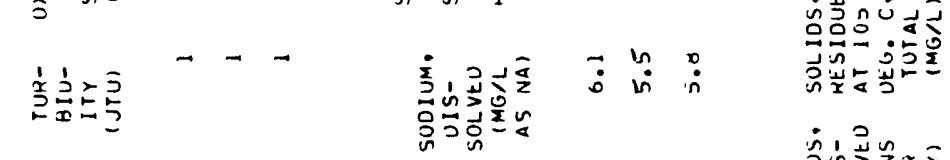

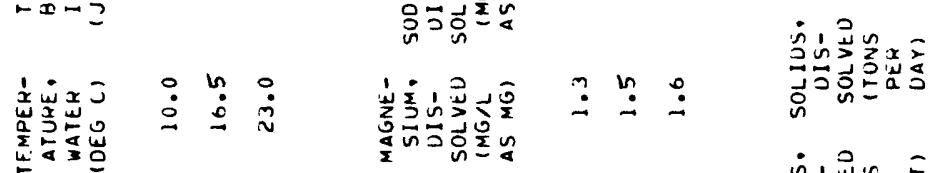

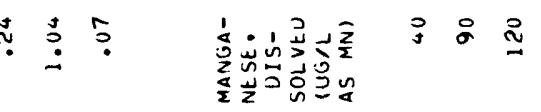

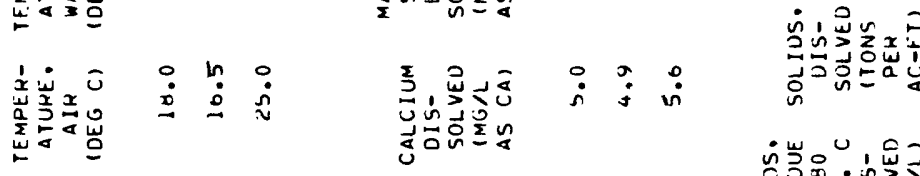

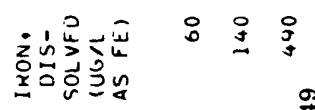

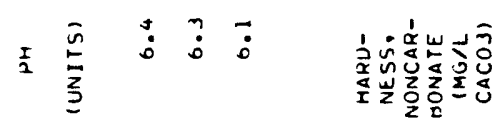

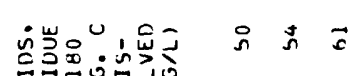

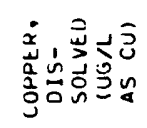

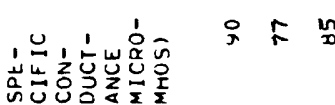

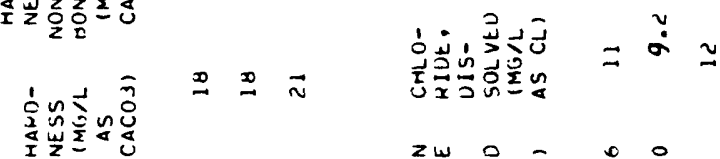

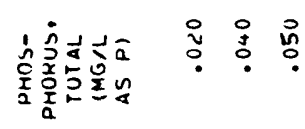

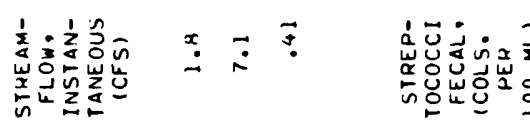

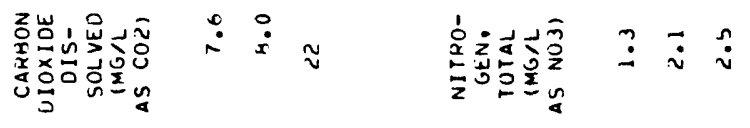

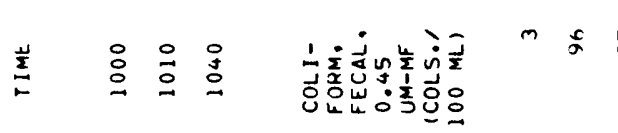

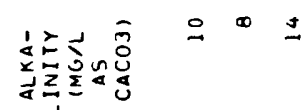

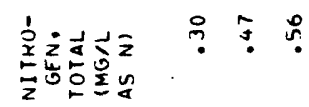

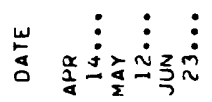

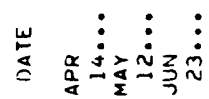

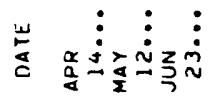

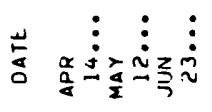




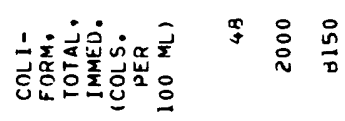

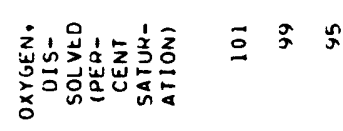

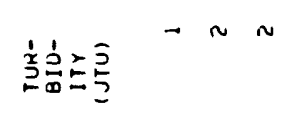

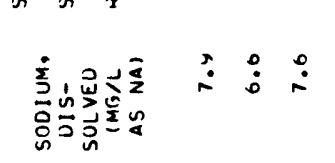

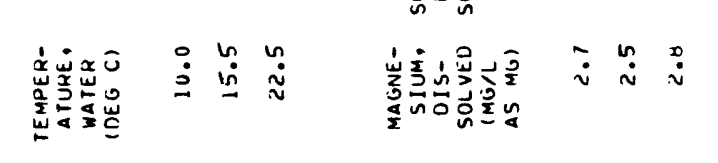

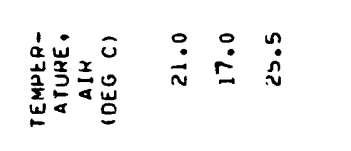

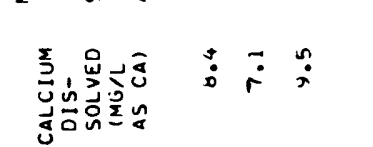

ธ

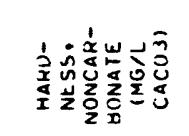

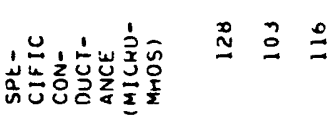

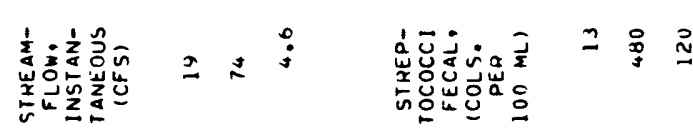

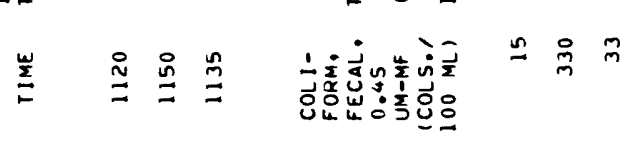

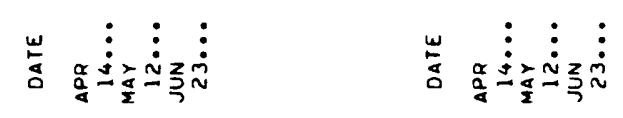

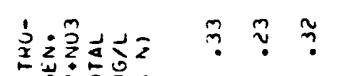

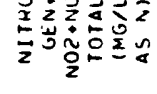

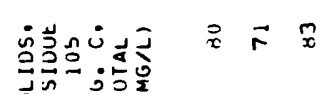

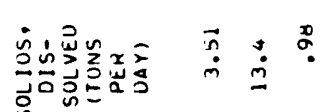

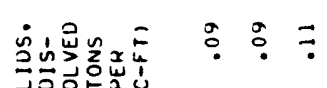

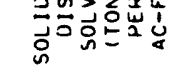

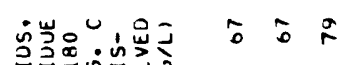

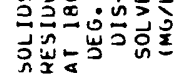

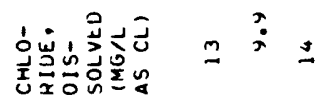

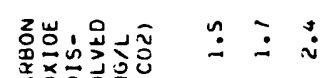

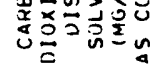

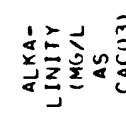

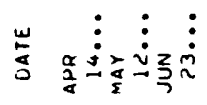

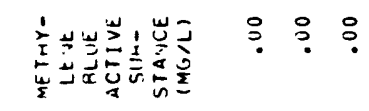

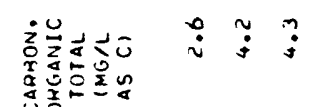

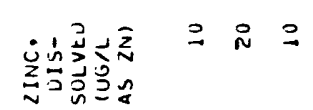

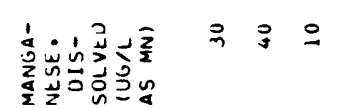

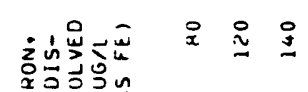
- nบa

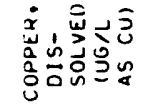

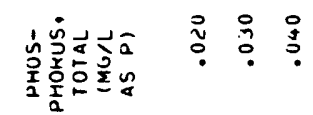

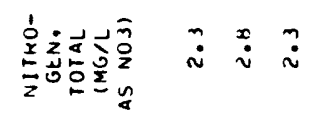

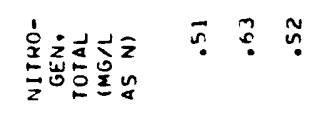

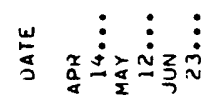




\section{SELECTEN REFERENCES}

Brown, Eugene, Skougstad, M. W., and Fishman, M. J., 1974, Methods for collection and analysis of water samples for dissolved minerals and gases: II.S. Geological Survey Techniques of Water Resources-Investigations, Book 5, Chap. Al, $160 \mathrm{p}$.

Buchanan, T. J., Somers, W. P., 1969, Discharge measurements at gaging stations: U.S. Geological Survey Techniques of Water-Resources Investigations, Book 3, Chap. A8, $65 \mathrm{p}$.

Connecticut Department of Environmental Protection, 1977, Connecticut Water Quality Standards and Classifications: State of Connecticut Department of Environmental Protection, $90 \mathrm{p}$.

1980, Connecticut Water nuality Standards and Criteria: State of Connecticut Department of Environmental Protection, $28 \mathrm{p}$.

Greeson, P. E., Ehlke, T. A., Irwin, G. A., Lium, B. W., Slack, K. V., 1977, Methods for collection and analysis of aquatic biological and microbiological samples: U.S. Geological Survey Techniques of Water-Resources Investigations, Book 5, Chap. A4, $332 \mathrm{p}$.

Kroll, R. L., 1977, The bedrock geology of the Norwalk North and Norwalk South quadrangle: State Geological and Natural History Survey of Connecticut, Quadrangle Report No. 34, $55 \mathrm{p}$.

Millipore Corporation, 1973, Biological analysis of water and wastewater: Millipore Corp., AM302, $84 \mathrm{p}$.

Ryder, R. B., Cervione, M. A., Jr., Thomas, C. E. Jr., and Thomas, M. P., 1970, Water resources inventory of Connecticut, part 4, southwestern coastal river basins: Connecticut Water-Resources Bulletin No. 17, 54 p.

U.S. Environmental Protection Agency, 1975, National interim primary drinking water regulations: Federal Register, v. 40, no. 248, p. 59566-59588.

1977, Quality criteria for water: U.S. Environmental Protection Agency Report, 256 .

1977, Proposed national secondary drinking water regulations: Federal Register, v. 42, no. 62, p. 17143-17147. 